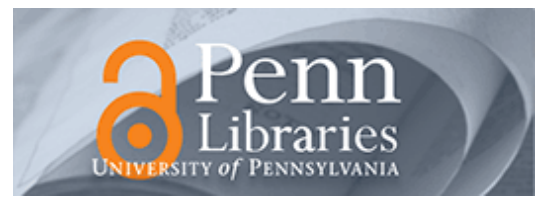

University of Pennsylvania

ScholarlyCommons

Accounting Papers

Wharton Faculty Research

$12-2008$

\title{
Mandatory IFRS Reporting Around the World: Early Evidence on the Economic Consequences
}

Holger Daske

Luzi Hail

University of Pennsylvania

Christian Leuz

Rodrigo S. Verdi

Follow this and additional works at: https://repository.upenn.edu/accounting_papers

Part of the Accounting Commons, and the International Business Commons

\section{Recommended Citation}

Daske, H., Hail, L., Leuz, C., \& Verdi, R. S. (2008). Mandatory IFRS Reporting Around the World: Early Evidence on the Economic Consequences. Journal of Accounting Research, 46 (5), 1085-1142.

http://dx.doi.org/10.1111/j.1475-679X.2008.00306.x

This paper is posted at ScholarlyCommons. https://repository.upenn.edu/accounting_papers/64

For more information, please contact repository@pobox.upenn.edu. 


\title{
Mandatory IFRS Reporting Around the World: Early Evidence on the Economic Consequences
}

\begin{abstract}
This paper examines the economic consequences of mandatory International Financial Reporting Standards (IFRS) reporting around the world. We analyze the effects on market liquidity, cost of capital, and Tobin's $q$ in 26 countries using a large sample of firms that are mandated to adopt IFRS. We find that, on average, market liquidity increases around the time of the introduction of IFRS. We also document a decrease in firms' cost of capital and an increase in equity valuations, but only if we account for the possibility that the effects occur prior to the official adoption date. Partitioning our sample, we find that the capital-market benefits occur only in countries where firms have incentives to be transparent and where legal enforcement is strong, underscoring the central importance of firms' reporting incentives and countries' enforcement regimes for the quality of financial reporting. Comparing mandatory and voluntary adopters, we find that the capital market effects are most pronounced for firms that voluntarily switch to IFRS, both in the year when they switch and again later, when IFRS become mandatory. While the former result is likely due to self-selection, the latter result cautions us to attribute the capital-market effects for mandatory adopters solely or even primarily to the IFRS mandate. Many adopting countries make concurrent efforts to improve enforcement and governance regimes, which likely play into our findings. Consistent with this interpretation, the estimated liquidity improvements are smaller in magnitude when we analyze them on a monthly basis, which is more likely to isolate IFRS reporting effects.
\end{abstract}

\section{Keywords}

regulation, international accounting, IAS, U.S. GAAP, disclosure, market liquidity, cost of equity, enforcement, security markets

\section{Disciplines}

Accounting | International Business 


\title{
Mandatory IFRS Reporting Around the World: Early Evidence on the Economic Consequences*
}

\author{
Holger Daske \\ University of Mannheim \\ Luzi Hail \\ The Wharton School, University of Pennsylvania \\ Christian Leuz \\ The Graduate School of Business, University of Chicago \\ Rodrigo Verdi \\ Sloan School of Management, MIT \\ August 2008 \\ (Forthcoming in the Journal of Accounting Research)
}

\begin{abstract}
This paper examines the economic consequences of mandatory IFRS reporting around the world. We analyze the effects on market liquidity, cost of capital and Tobin's q in 26 countries using a large sample of firms that are mandated to adopt IFRS. We find that, on average, market liquidity increases around the time of the introduction of IFRS. We also document a decrease in firms' cost of capital and an increase in equity valuations, but only if we account for the possibility that the effects occur prior to the official adoption date. Partitioning our sample, we find that the capital-market benefits occur only in countries where firms have incentives to be transparent and where legal enforcement is strong, underscoring the central importance of firms' reporting incentives and countries' enforcement regimes for the quality of financial reporting. Comparing mandatory and voluntary adopters, we find that the capital market effects are most pronounced for firms that voluntarily switch to IFRS, both in the year when they switch and again later, when IFRS become mandatory. While the former result is likely due to self-selection, the latter result cautions us to attribute the capital-market effects for mandatory adopters solely or even primarily to the IFRS mandate. Many adopting countries have made concurrent efforts to improve enforcement and governance regimes, which likely play into our findings. Consistent with this interpretation, the estimated liquidity improvements are smaller in magnitude when we analyze them on a monthly basis, which is more likely to isolate IFRS reporting effects.
\end{abstract}

JEL classification: G14, G15, G30, K22, M41, M42

Key Words: $\quad$ Regulation, International accounting, IAS, U.S. GAAP, Disclosure, Market liquidity, Cost of equity, Enforcement, Security markets

\footnotetext{
*We appreciate the helpful comments of Ray Ball, Phil Berger, Hans Christensen, John Core, Ray Donnelly, Günther Gebhardt, Bob Holthausen, Andrew Karolyi, Steve Matsunaga, Jim Mc Keown, Martin Wallmeier, Michael Welker, and workshop participants at the 2008 American Accounting Association meeting, American University, Bucerius Law School, University of Chicago, Chinese University's CIG conference, Columbia University, Darden School, UC Davis Financial Markets Research conference, 2008 European Accounting Association meeting, Lancaster University, New York University, University of Oregon, Queen's University, Tilburg University, 2008 VHB Frühjahrstagung, 2008 Western Finance Association meeting, and the Wharton School. Christian Leuz gratefully acknowledges research funding provided by the Initiative on Global Markets (IGM) at the University of Chicago, Graduate School of Business. Holger Daske gratefully acknowledges the financial contribution of the European Commission Research Training Network INTACCT.
} 


\section{Introduction}

The introduction of International Financial Reporting Standards (IFRS) for listed companies in many countries around the world is one of the most significant regulatory changes in accounting history. ${ }^{1}$ Over 100 countries have recently moved to IFRS reporting or decided to require the use of these standards in the near future and even the U.S. Securities and Exchange Commission (SEC) is considering allowing U.S. firms to prepare their financial statements in accordance with IFRS (www.sec.gov/news/press/2007/2007-145.htm). Regulators expect that the use of IFRS enhances the comparability of financial statements, improves corporate transparency, increases the quality of financial reporting, and hence benefits investors (e.g., EC Regulation No. 1606/2002). From an economic perspective, there are reasons to be skeptical about these expectations and, in particular, the premise that simply mandating IFRS makes corporate reporting more informative or more comparable. Thus, the economic consequences of mandating IFRS reporting are not obvious.

In this paper, we provide early evidence on the capital-market effects around the introduction of mandatory IFRS reporting in 26 countries around the world. Using a treatment sample of over 3,100 firms that are mandated to adopt IFRS, we analyze effects in stock market liquidity, cost of equity capital, and firm value. These market-based constructs should reflect, among other things, changes in the quality of financial reporting and hence should also reflect improvements around the IFRS mandate. We employ four proxies for market liquidity, i.e., the proportion of zero returns, the price impact of trades, total trading costs, and bid-ask spreads, four methods to compute the implied cost of equity capital, and use Tobin's q as a proxy for firms' equity valuations.

The primary challenge of our analysis is that the application of IFRS is mandated for all publicly traded firms in a given country from a certain date on. This makes it difficult to find a benchmark

1 International Accounting Standards (IAS) were renamed to IFRS in 2001. We use IAS and IFRS interchangeably but our analysis does not presume or require that earlier IAS and later IFRS adoptions have the same consequences. 
against which to evaluate any observed capital-market effects. Our empirical strategy uses three sets of tests to address this issue. First, using firm-year panel data from 2001 to 2005, we benchmark liquidity, cost of capital and valuation effects around the introduction of IFRS against changes in other countries that do not yet mandate or allow IFRS reporting. We also include firms from IFRS adoption countries that do not yet report under IFRS at the end of our sample period because their fiscal year ends after December 2005, which, except for Singapore, is the date from which on our sample firms must use IFRS. Both benchmarks help us to control for contemporaneous capitalmarket effects that are unrelated to the introduction of IFRS. In addition, we introduce firm-fixed effects to account for unobserved time-invariant firm characteristics.

Second, still using firm-year panel data, we examine whether the estimated capital-market effects exhibit plausible cross-sectional variation with respect to countries' institutional frameworks. As the regulatory change forces many firms to adopt IFRS that would not have done so otherwise, we expect mandatory IFRS reporting to have a smaller effect or no impact in countries with weak legal and enforcement regimes or where firms have poor reporting incentives to begin with. Moreover, assuming that mandatory IFRS reporting is properly enforced, the impact is likely to be smaller in countries that already have high reporting quality or where local GAAP and IFRS are fairly close (e.g., due to a prior convergence strategy).

Third, we exploit that firms begin applying IFRS at different points in time depending on their fiscal-year ends and that, as a result, the adoption pattern in a given country is largely exogenous once the initial date for IFRS adoption is set. ${ }^{2}$ We relate this pattern to changes in aggregate liquidity in a given country and month. If the introduction of IFRS reporting has indeed discernable effects,

2 We note that the initial date (and whether a country sticks to it) is likely to be endogenous to current political and market conditions. However, once the date is set and adoption begins, the pattern is largely given, which is what our identification strategy exploits. 
we expect changes in aggregate liquidity to be most pronounced in months when many firms report under IFRS for the first time. That is, changes in liquidity should mirror countries' stepwise transition towards the new reporting regime and not simply reflect a time trend or a one-time shock. As this approach has fewer data restrictions, we analyze liquidity effects for 6,500 mandatory adopters, i.e., firms that report under IFRS for the first time when it becomes mandatory.

We begin our first set of analyses with a simple difference-in-differences analysis and find that mandatory adopters exhibit a significantly larger increase in market liquidity than a random sample of non-adopting benchmark firms from around the world. In contrast, the changes in Tobin's q for mandatory adopters are insignificant and their cost of capital even increases relative to benchmark firms. While the latter findings may be surprising, they do not yet account for the possibility that markets likely price the IFRS mandate ahead of the actual adoption date.

Next, we run firm-level panel regressions that control for time-varying firm characteristics, market-wide changes in the dependent variable, industry-year-fixed, and firm-fixed effects. We find that market liquidity increases for firms that adopt IFRS reporting when it becomes mandatory. In our main specification, the percentage of days without trades declines by 100 basis points for mandatory adopters, which is close to a $4 \%$ liquidity improvement relative to the median level prior to IFRS adoption. Total trading costs and the percentage bid-ask spreads both decline by 12 basis points, indicating liquidity increases of $3 \%$ and $6 \%$, respectively, relative to the median level prior to IFRS adoption. The results for price impact are insignificant in the main specification. For parsimony and to reduce measurement error, we aggregate all four liquidity proxies into a single liquidity factor and again find a statistically significant increase in liquidity for mandatory IFRS adopters. We also vary the composition of the benchmark sample using the complete Worldscope population or U.S. firms only. While these variations do not change the tenor of the results, they 
indicate that benchmarking and the specific choice of the benchmark are important in evaluating the liquidity effects around the IFRS mandate.

The cost of capital and Tobin's q results are mixed. Our base specification indicates an increase in the cost of capital and a decrease of Tobin's $q$ in the year when IFRS reporting becomes mandatory, similar to the difference-in-differences analysis. It is possible, though, that these results stem from transition effects, such as temporary difficulties to forecast earnings under the new accounting regime, which can affect the implied cost of capital, or changes in the measurement of total assets, which can affect Tobin's q. Another explanation is that markets anticipate the effects of the IFRS mandate, in which case including observations of switching firms before the introduction of IFRS (as our panel approach does) likely works against finding a decrease (increase) in the cost of capital (Tobin's q). Consistent with the existence of anticipation effects, we find that the cost of capital decreases by 26 basis points and Tobin's q increases by $7 \%$ when we measure the effect one year before the mandatory adoption date.

While the liquidity and the (anticipation-adjusted) cost of capital and valuation effects for mandatory adopters are economically significant, they are generally smaller than the corresponding capital-market effects of voluntary adopters. That is, the latter group exhibits significant liquidity, valuation and cost of capital effects around the introduction of mandatory IFRS reporting, despite the fact that these firms have already switched to IFRS prior to the mandate. ${ }^{3}$ There are several ways to interpret this finding. First, it could reflect comparability benefits that accrue to the voluntary adopters when the other firms in the country have to switch to IFRS. We conduct some tests on the

3 In addition, we find significant liquidity and valuation benefits for firms that adopt IFRS ahead of the mandated change. We label these firms "late voluntary" adopters as they switch after their home country announces the move to mandatory IFRS reporting. One can also think of them as "early mandatory" adopters. Their adoption effects have to be interpreted cautiously as they likely reflect self-selection, rather than IFRS reporting itself (see also Daske et al. [2007]). 
role of comparability effects, but are unable to provide statistical support for this argument. Second, the capital-market effects for voluntary adopters could stem from concurrent changes in the enforcement and governance regimes that (some) countries have introduced together with the IFRS mandate. Such changes should affect mandatory and voluntary adopters in a given country and, hence, could explain the capital-market effects. Our cross-sectional results, which we discuss next, are consistent with this interpretation. Finally, as the capital-market effects are particularly pronounced for early voluntary adopters, it is also possible that the mandate increases the commitment associated with IFRS reporting as it eliminates dual reporting practices and the option to reverse back to local GAAP.

Our second set of empirical tests, the cross-sectional analyses, show that the capital-market effects around the introduction of mandatory IFRS reporting are not evenly distributed across countries and firms. We find that the capital markets effects around mandatory IFRS adoption occur only in countries with relatively strict enforcement regimes and in countries where the institutional environment provides strong incentives to firms to be transparent. These findings are consistent with the view that IFRS implementation is likely to be heterogeneous across countries (e.g., Ball [2006]), and with the idea that firms' reporting incentives, which are shaped by markets and countries' institutional environments, play a crucial role for reporting outcomes (e.g., Ball, Robin, and Wu [2003], Ball and Shivakumar [2005], Burgstahler, Hail, and Leuz [2006]). We also find that the effects for mandatory adopters are smaller in countries that have fewer differences between local GAAP and IFRS and a pre-existing convergence strategy towards IFRS. As expected under the reporting incentives view, these effects are largest for countries with large GAAP differences that also have strong legal regimes. Finally, capital-market effects are stronger in member states of the European Union (EU), possibly reflecting its concurrent efforts to improve governance and enforcement (Hail and Leuz [2007]). 
In our last set of analyses, we examine monthly changes in aggregate liquidity as IFRS reporting becomes more widespread, controlling for contemporaneous changes in world market liquidity averaged over a 100 random samples, changes in liquidity for the same calendar month in the prior year, lagged levels in liquidity, volatility, market capitalization, and country-fixed effects. We show that increases in IFRS reporting by mandatory adopters are associated with decreases in the percentage of zero returns, in bid-ask spreads and, to a lesser extent, in the price impact of trades. These findings confirm our firm-year analyses but are considerably smaller in magnitude. As the country-month analysis is likely the cleanest test in terms of separating the consequences of the IFRS mandate from other factors (e.g., time trends, unrelated institutional changes), the smaller magnitude of the effects provides further evidence that the documented liquidity improvements in the firm-year analysis cannot be attributed entirely to the IFRS mandate. ${ }^{4}$

Despite the consistency of our findings across various analyses, we caution the reader to interpret this study carefully. First, as several countries around the world have substantially revised their enforcement, auditing and governance regimes to support the introduction of IFRS reporting, it is likely that our results reflect the joint effects of these efforts and hence cannot solely, or even primarily, be attributed to the switch to IFRS. Second, our analyses are based on a relatively short time period and it is possible that the documented effects are short-lived. But the effects could also increase over time as market participants gain more experience with IFRS or as recent changes to countries' enforcement and governance regimes take further hold. Third, our valuation and cost of capital proxies may exhibit substantial measurement error and, in particular, may be affected by the change in accounting measurement per se, which in turn could bias the magnitude of the estimated effects. For instance, taken at face value, our estimates of the valuation effects seem too large to be

4 An alternative explanation is lack of power. The country-month approach, which we implement in changes, is more sensitive to the timing of the information release. Leakage of information or errors in assigning the publication of firms' financial reports to a particular month likely hurt this analysis more than the firm-year approach. 
solely attributable to the IFRS mandate. Finally, while we attempt to account for anticipation and early pricing of the IFRS mandate as well as first-time IFRS interim reporting, these effects and transitional procedures (see IFRS 1) likely reduce the power of our tests.

With these caveats in mind, our study makes several contributions to the literature. This study is the first to analyze the capital-market effects around the introduction of mandatory IFRS reporting for a large and global sample of firms. The move to mandatory IFRS reporting around the world is one of the most important policy issues in financial accounting. Hence, the findings should be of substantial interest to regulators and policy makers in many countries, including those that have not yet made the decision to move towards IFRS. Our study is also novel in that it examines the economic consequences of a mandatory change of an entire set of accounting standards as well as the heterogeneity in these capital-market effects across many countries and industries. Prior studies either perform analyses across countries with different accounting standards or are based on voluntary adoptions of new accounting standards. Finally, our study illustrates a novel empirical strategy to identify the effects of mandatory accounting regime changes. We exploit that IFRS reporting is phased-in based on firms' fiscal-year ends. Thus, our country-month analysis should allow us to disentangle time trends, one-time shocks, and reporting-related effects.

The remainder of the paper is organized as follows. Section 2 develops our hypotheses and reviews the literature. Section 3 delineates our research design for the firm-year analyses and presents results for the average capital market effects around the switch to IFRS reporting. In Section 4, we examine the heterogeneity in the capital market effects across countries and industries. Section 5 presents the country-month analyses, and Section 6 concludes. In the Appendix, we provide additional details on the construction of our key variables. 


\section{Conceptual Underpinnings and Literature Review}

\subsection{HYPOTHESIS DEVELOPMENT}

In this section, we discuss several hypotheses about the effects of introducing IFRS reporting around the world. There are arguments suggesting significant capital-market effects (in either direction) around the adoption of mandatory IFRS reporting as well as arguments that point towards small or negligible effects. As all of these views have merit, the capital-market effects of mandatory IFRS reporting are ultimately an empirical question.

Arguments suggesting that the adoption of mandatory IFRS reporting yields significant capitalmarket benefits often start from the premise that IFRS reporting increases transparency and improves the quality of financial reporting (e.g., EC Regulation No. 1606/2002), citing that IFRS are more capital-market oriented and more comprehensive, especially with respect to disclosures, than most local GAAP. ${ }^{5}$ To the extent that this premise is correct, prior analytical and empirical studies suggest that the introduction of mandatory IFRS reporting should be associated with an increase in market liquidity as well as a decline in firms' cost of capital. That is, higher quality financial reporting and better disclosure should reduce adverse selection problems in share markets and lower estimation risk (e.g., Verrecchia [2001], Lambert, Leuz, and Verrecchia [2007]). Welker [1995], Healy, Hutton, and Palepu [1999] and Leuz and Verrecchia [2000] provide evidence that information asymmetry and liquidity proxies are indeed associated with firms' disclosure and accounting policies. Similarly, Botosan [1997], Botosan and Plumlee [2002], Hail [2002], Francis et al. [2004], and Hail and Leuz [2006] show that more extensive financial disclosures and higher quality reporting are negatively related to firms' (implied) cost of equity capital. Based on this prior work, we expect that market

5 For instance, Barth, Landsman, and Lang [2008] provide evidence that earnings quality increases around voluntary IAS adoptions. Daske and Gebhardt [2006] show similar results for the perception of disclosure quality. See Ding et al. [2007] and Bae, Tan, and Welker [2008] for a comparison of various standards and evidence that IFRS are more comprehensive than most local GAAP. 
liquidity, cost of capital and firm value reflect, among other things, firms' reporting quality. Thus, we can use these proxies to evaluate mandatory reporting changes, such as the imposition of IFRS.

A related argument in favor of positive capital-market effects is that IFRS reduce the amount of reporting discretion relative to many local GAAP and, in particular, compel firms towards the bottom of the quality spectrum to improve their financial reporting. Consistent with this argument, Ewert and Wagenhofer [2005] show that tightening the accounting standards can reduce the level of earnings management and improve reporting quality. ${ }^{6}$

Another argument is that IFRS reporting make it less costly for investors to compare firms across markets and countries (e.g., Armstrong et al. [2007], Covrig, DeFond, and Hung [2007]). Thus, even if the quality of corporate reporting per se does not improve, it is possible that the financial information provided becomes more useful to investors. For instance, a common set of accounting standards could help investors to differentiate between lower and higher quality firms, which in turn would reduce information asymmetries among investors and/or lower estimation risk. Moreover, if IFRS reporting improves comparisons across firms and reduces estimation risk, the switch to IFRS creates positive externalities on other firms, and mandating IFRS would be one way to capture them (e.g., Coffee [1984], Dye [1990], Lambert, Leuz, and Verrecchia [2007]). Similarly, accounting diversity could be an impediment to cross-border investment (Bradshaw, Bushee, and Miller [2004]). The global movement towards IFRS reporting may facilitate cross-border investment and the integration of capital markets (Covrig, DeFond, and Hung [2007]). Making it easier for foreigners to

6 Conversely, reducing the amount of reporting discretion could make it harder for firms to convey information through their financial statements (e.g., Watts and Zimmerman [1986]). Also, IFRS might not be as adapted to the local environment as the pre-existing GAAP. In addition, there can be transition effects, e.g., the switch to a new reporting regime could make it harder for analysts to forecast earnings. Thus, it is even conceivable that mandating the use of IFRS has detrimental capital-market effects, e.g., increases the cost of capital, at least for some time. 
invest in a country's firms could again improve the liquidity of the capital markets and enlarge firms' investor base, which in turn improves risk-sharing and lowers cost of capital (e.g., Merton [1987]).

However, there are also arguments suggesting that the capital-market effects of IFRS adoption could be small or even negligible. In particular, there are reasons to be skeptical about the premise that mandating the use of IFRS alone makes corporate reporting more informative or more comparable. The evidence in several recent studies points to a limited role of accounting standards in determining observed reporting quality and, in contrast, highlights the importance of firms' reporting incentives (e.g., Ball, Kothari, and Robin [2000], Ball, Robin, and Wu [2003], Leuz [2003], Ball and Shivakumar [2005], Burgstahler, Hail, and Leuz [2006]). The argument behind this evidence is that the application of accounting standards involves considerable judgment and the use of private information. As a result, IFRS (like any other set of accounting standards) provide firms with substantial discretion. How firms use this discretion is likely to depend on their reporting incentives, which are shaped by many factors, including countries' legal institutions, various market forces and firms' operating characteristics.

Thus, the reporting incentives argument questions that changing the standards alone makes the reported numbers more comparable across firms or improves firms' reporting behavior. Firms that oppose the switch to IFRS or towards more transparency are unlikely to make material changes to their reporting policies (e.g., Ball [2006], Daske et al. [2007]). This concern applies not only to recognition and valuation rules, where firms are known to have substantial discretion, but also to footnote disclosures, which firms can make in a more or less informative manner. ${ }^{7}$ Thus, even if the standards themselves mandate superior accounting practices and require more disclosures, it is not

7 In fact, missing or insufficient footnote disclosures are frequently an issue according to the reviews of IFRS financial statements that the British FRRP (Financial Reporting Review Panel), the newly created French AMF (Autorité des Marchés Financiers) and German FREP (Financial Reporting Enforcement Panel) conducted. 
clear whether firms implement these standards in ways that make the reported numbers indeed more informative. ${ }^{8}$ We note that this is not just a matter of proper enforcement. Even with perfect enforcement, observed reporting behavior is expected to differ across firms as long as accounting standards offer some discretion and firms have different reporting incentives (Leuz [2006]).

That said, enforcement is an important issue for our study because many countries have revised and strengthened their enforcement regimes along with the introduction of mandatory IFRS reporting. For instance, the EU has made several such efforts in recent years. In 2003, the Committee of European Securities Regulators (CESR) released its Standard No. 1. While it is nonbinding, it is aimed at developing and implementing a common approach to the enforcement of IFRS throughout the EU. Among other things, the standard stipulates that all listed companies are subject to a financial information review and calls for the creation of an independent administrative authority for compliance and enforcement in each member state. In 2004, the EU passed the Transparency Directive, which builds expressively on regulation mandating IFRS reporting and establishes rules for periodic financial reports and other continuing reporting obligations. For instance, it mandates that financial reports include a responsibility statement by corporate insiders and stipulates the creation of enforcement authorities that assume responsibility for IFRS compliance. EU member states had to implement the directive by January 2007. In addition, IFRS implementation and enforcement has received widespread attention from auditors and the press, ${ }^{9}$ and in many countries, the importance of public capital markets has increased substantially in recent years.

8 However, as noted above, it is also possible that imposing a single set of accounting standards on firms around the world makes it easier for investors to compare firms' accounting practices, which in turn improves investors' and regulators' ability to detect earnings management and thereby changes firms' reporting incentives.

9 See, e.g., the Financial Times' website (http://www.ft.com/indepth/accounting) or the reports by Big Four auditing firms on IFRS implementation (e.g., KPMG [2006], Ernst \& Young [2007] or PwC/Ipsos MORI [2007]). 
Such institutional changes can alter firms' reporting incentives and hence lead to higher quality reporting. If these changes take place around the introduction of mandatory IFRS reporting and significantly tighten the enforcement regime compared to one in place under local GAAP reporting, the capital-market effects around IFRS adoption are likely the joint outcome of concurrent reporting and enforcement changes. Similar arguments can be made for recent governance and auditing reforms in many countries (e.g., Enriques and Volpin [2007], Quick, Turley, and Willekens [2008]).

The reporting incentives view predicts that countries' institutional structures and changes therein play an important role in explaining capital-market effects around IFRS adoption. All else equal, countries with stricter enforcement regimes and institutional structures that provide strong reporting incentives are more likely to exhibit discernable capital-market effects around the introduction of IFRS reporting. In these countries, mandatory adopters are less likely to get away with adopting IFRS merely as a label, i.e., without materially changing their reporting practices. ${ }^{10}$ Conversely, one could argue that countries with better reporting practices before the introduction of IFRS should experience smaller capital-market effects. ${ }^{11}$ This argument, however, rests on the presumption that changing the accounting standards alone improves firms' reporting practices and ignores institutional reasons why firms in these countries have better reporting quality to begin with.

For similar reasons, we expect capital-market effects to be different across voluntary and mandatory adopters. The latter group is essentially forced to adopt IFRS and hence should respond less to the treatment. The former set of firms is more likely to make significant changes to their reporting practices. Some of them may adopt IFRS as part of a broader strategy that increases their

10 Heterogeneity is also apparent in the way in which countries adopt IFRS and related IFRIC interpretations (e.g., wholesale adoption, standard-by-standard adoption, modifications or exclusion of selected standards). See www.iasplus.com for an overview of various implementation strategies.

11 In addition, there may be limits to how much market liquidity and the cost of capital can improve as a result of reporting quality increases. These constraints are more binding for countries where the quality is already high. 
commitment to transparency, e.g., they may hire higher quality auditors, improve corporate governance, change ownership structures, or seek cross-listings in stricter regimes, along with IFRS adoption. As a result, the capital-market effects around voluntary adoptions are likely to be larger but they cannot be attributed to IFRS alone. That is, the effects might reflect differences in the incentives for credible reporting, the circumstances that led to IFRS adoption in the first place, and a firm's entire commitment strategy (e.g., Leuz and Verrecchia [2000], Daske et al. [2007]).

At the same time, firms that have already voluntarily switched to IFRS prior to the mandate should not exhibit significant capital-market effects when IFRS reporting becomes mandatory unless the latter compels them to increase their commitment to transparency or the mandate creates positive externalities. For example, it is possible that these firms benefit from greater comparability as all the other firms in the country switch to IFRS. Another possibility is that capital-market effects for voluntary adopters around the time IFRS becomes mandatory reflect the concurrent changes in countries' institutional environments, such as improvements in enforcement and governance.

\subsection{RELATED EMPIRICAL STUDIES}

In this section, we briefly summarize evidence on the capital-market effects of IFRS adoption. We focus primarily on studies examining the introduction of mandatory IFRS reporting. Studies examining voluntary adoptions do not speak directly to the costs and benefits of an IFRS reporting requirement. ${ }^{12}$ Studies on the introduction of mandatory IFRS reporting can be classified into two categories: (1) Studies that examine the stock market reactions to key events associated with the EU's movement towards mandatory IFRS reporting and (2) a few recent studies that analyze the effects of

12 These studies nevertheless provide useful insights that can help in forming expectations and interpreting the effects of mandatory IFRS reporting. See Barth, Landsman, and Lang [2008] and Daske et al. [2007] as examples and for reviews of these studies. 
mandatory IFRS adoption in certain countries based on IFRS financial statements. ${ }^{13}$ Overall, evidence on the consequences of mandatory IFRS reporting is still in its infancy.

Studies in the first category try to infer whether the adoption of IFRS in the EU has net benefits (or costs) to firms from their stock market reactions to key events that made IFRS reporting more or less likely. The evidence from these papers is mixed. Comprix, Muller, and Standford-Harris [2003] examine abnormal returns of EU firms on four "core" event dates in 2000 that increased the likelihood of mandatory IFRS reporting. They find a weakly significant, but negative market reaction to the four event dates. However, firms that are audited by a big five auditor, located in countries that are expected to have greater improvements in reporting quality due to IFRS adoption, or subject to higher legal enforcement experience significantly positive returns on some of the event dates they examine. Armstrong et al. [2007] examine the reactions to 16 events between 2002 and 2005 associated with the adoption of IFRS in the EU. They find a positive (negative) reaction to events that increase (decrease) the likelihood of IFRS adoption. They also document that the reaction is more positive for firms from lower quality information environments, with higher pre-adoption information asymmetry, and firms that are domiciled in common law countries. Christensen, Lee, and Walker [2007a] analyze the market reactions of U.K. firms to announcements of mandatory IFRS reporting in the EU and find that the average U.K. market reaction is small. Using the degree of similarity with German voluntary IFRS and U.S. GAAP adopters as a proxy for U.K. firms' willingness to adopt IFRS, they find that this proxy is positively (negatively) related to the stock price reaction to news events increasing (decreasing) the likelihood of mandatory IFRS reporting. They find a similar association for changes in the implied cost of equity capital.

13 A related literature compares the quality and economic outcomes of IAS/IFRS and U.S. GAAP reporting in particular market settings. Leuz [2003] compares the liquidity and IPO underpricing of firms in Germany's former New Market that had to report under either IAS or U.S. GAAP. Gordon, Jorgensen, and Linthicum [2008] and Hughes and Sander [2007] exploit that U.S. cross-listed firms reporting under IFRS have to reconcile their earnings to U.S. GAAP and study the incremental value relevance and magnitude of the reconciliations, respectively. 
Studies in the second category analyze the effects of mandated IFRS using data from the annual reports released under the new regime. These studies are closest in spirit to our firm-year analyses. However, they are limited to particular countries and often quite different in their research focus or design. Platikanova [2007] analyzes measures of liquidity and information asymmetry in four European countries. She finds heterogeneous liquidity changes for these countries but documents that the liquidity differences across countries become smaller after the adoption of IFRS. Demaria and Dufour [2007] and Capkun et al. [2008] examine transitional effects and changes in accounting numbers (or ratios) when firms switch from local GAAP to IFRS. Christensen, Lee, and Walker [2007b] analyze whether IFRS/UK GAAP reconciliations around the IFRS introduction convey new information to the markets, and find that reconciliations that are released early do so. Capkun et al. [2008] find that earnings reconciliations of EU firms in the transition year are value relevant.

Finally, several reports examine the implementation and compliance of IFRS in the first year under the new mandate. While a study conducted by the Institute of Chartered Accountants in England and Wales (ICAEW [2007]) on behalf of the European Commission suggests that publicly traded firms in the EU generally comply with IFRS, similar studies by KPMG [2006] and Ernst \& Young [2007] conclude that, despite substantial convergence, IFRS financial statements retain a strong national identity, which is consistent with the reporting incentives view. ${ }^{14}$

\section{Firm-Year Analyses of the Capital-Market Effects around the IFRS Mandate}

\subsection{RESEARCH DESIGN}

To conduct our first set of empirical tests, the firm-year panel regressions, we proceed in four steps. First, we define the key variables of interest and divide all IFRS adopters into three categories:

14 For similar and related evidence from the earnings properties of firms with U.S. cross-listings see Lang, Smith Raedy, and Wilson [2006] and Leuz [2006]. 
mandatory, early voluntary, and late voluntary adopters. We create a binary indicator variable, FirstTime Mandatory, that takes on the value of one for fiscal years ending on or after the local IFRS adoption date (in most cases December 31, 2005) from firms that do not report under IFRS until it becomes mandatory. This variable should capture the average capital-market effects around the IFRS mandate for firms that are essentially forced to adopt IFRS. It is the main variable of interest. We introduce separate indicator variables for firm-year observations from firms that report under IFRS ahead of the rule change. We distinguish between Early Voluntary and Late Voluntary adopters, respectively, depending on whether firms switch to IFRS before their home country announced plans to require IFRS reporting or after this announcement, but before IFRS reporting becomes compulsory (see Table 6, Panel A, for IFRS announcement and adoption dates). ${ }^{15}$ We also define two interaction terms, Early Voluntary*Mandatory and Late Voluntary*Mandatory, marking all fiscal years ending on or after the mandated IFRS adoption date for the two respective groups. These terms capture any incremental (period-specific) capital-market effects for early and late voluntary adopters once IFRS reporting is required for all firms in the economy.

The second step is to choose dependent variables that capture the potential capital-market effects of the IFRS mandate described in Section 2. We use four proxies for market liquidity: Zero Returns is the proportion of trading days with zero daily stock returns out of all potential trading days in a given year. Price Impact is the yearly median of the Amihud [2002] illiquidity measure (i.e., daily absolute stock return divided by US\$ trading volume). Total Trading Costs are an estimate of total roundtrip transaction costs (including bid-ask spreads, commissions as well as implicit costs from short-sale constraints or taxes) based on a yearly time-series regression of daily stock returns on the

15 Note that coding IFRS reports in the pre-mandatory period is a non-trivial matter and requires assumptions about where to draw the line between local GAAP and IFRS (or IAS) reports. We follow Daske et al. [2007] in this matter. They code voluntary IFRS (and U.S. GAAP) reports based on the Worldscope accounting standards classification (Field 07536), which they then augment and triangulate using Global Vantage and an extensive manual collection of firms' annual reports. See Daske et al. [2007], Appendix A, for details. 
aggregate market returns (Lesmond, Ogden, and Trzcinka [1999]). Bid-Ask Spread is the yearly median of daily quoted spreads, measured at the end of each trading day as the difference between the bid and ask price divided by the mid-point. For parsimony, we also aggregate the four liquidity proxies into a single Liquidity Factor employing factor analysis with one oblique rotation, and use it as dependent variable in the analyses.

In addition, we examine effects on firms' cost of equity capital and equity valuations. We use four different accounting-based valuation models to obtain estimates of the cost of capital implied by the mean I/B/E/S analyst consensus forecasts and stock prices. Following Hail and Leuz [2006] and [2008], Cost of Capital is the average of these four estimates. We employ Tobin's $q$ as a proxy for firms' equity valuations and measure it as the market-to-book ratio of the total assets. The Appendix describes the theoretical concepts behind our proxies, the data sources and their empirical measurement in more detail.

We note that all capital-market proxies are related in the sense that liquidity effects could manifest in firms' cost of capital and that decreases in the cost of capital should increase Tobin's q. In addition, Tobin's q could capture effects beyond market liquidity and the cost of capital, e.g., real effects on investment or growth from better financial reporting and the costs of IFRS implementation. We also note that cost of capital estimates and Tobin's q are likely to capture capital-market effects of mandatory IFRS reporting early, even before the actual adoption of the standards, because these proxies reflect investors' expectations about the future and, hence, beyond IFRS adoption. ${ }^{16}$ In addition, both proxies can be affected by the change in the accounting rules. Implied cost of capital estimates could suffer because financial analysts have temporary difficulties to forecast earnings under the new regime and Tobin's q is likely affected by changes in the measurement of total assets

16 We present robustness checks in Section 3.3.3 to gauge the severity of this concern. 
due to the new accounting regime. ${ }^{17}$

The third step is to control for general trends and changes in market liquidity, cost of capital, or firm value that are unrelated to IFRS reporting. To do so, we include a sample of local GAAP benchmark firms from countries that either preclude or do not mandate the use of IFRS. We also include firms that do not yet have to report under IFRS due to their fiscal-year ends, but are from countries that require IFRS reporting. The latter firms are presumably subject to similar economic shocks as switching firms from the same country, which should help us control for contemporaneous effects that are unrelated to the introduction of IFRS. Moreover, we include industry-year-fixed effects, i.e., an indicator variable for each year and industry (using the Campbell [1996] industry classification) to capture common effects on our dependent variables in a particular year and industry. Finally, we include a contemporaneously measured Market Benchmark, computed as the yearly mean of the dependent variable from observations in countries that do not mandate IFRS reporting.

The fourth step is to include control variables for firm characteristics. In addition to industryyear-fixed effects and the market benchmark mentioned above, our regression models include firmfixed effects to control for unobserved time-invariant firm characteristics as well as binary indicator variables to control for U.S. GAAP reporting, U.S. cross-listing, trading on a "new market", and being member of a major stock index. In the liquidity regressions, we control for firm size, share turnover and return variability (Chordia, Roll, and Subrahmanyam [2000], Leuz and Verrecchia [2000]). ${ }^{18}$ For the cost-of-capital specifications, we follow Hail and Leuz [2006] and control for firm size, financial leverage, the risk-free rate, return variability, and forecast bias. The Tobin's q

17 We include contemporaneous forecast bias in our regression specification in order to control for analysts' difficulties in forecasting earnings during the transition period.

18 As is common in the market microstructure literature, we estimate the liquidity models in a log-linear specification, i.e., we use the natural logarithm of the continuous variables and lag the independent variables by one year where indicated in the tables (e.g., Stoll [1978], Glosten and Milgrom [1985]). 
regressions include firm size, financial leverage, asset growth and the average industry q (e.g., Doidge, Karolyi, and Stulz [2004], Lang, Lins, and Miller [2004]). All control variables are defined as stated in Table 1 (indicator variables) and Table 2 (continuous variables).

We combine the variables into the following regression model estimated at the firm-year level:

$$
\begin{aligned}
\text { EconCon }= & \beta_{0}+\beta_{1} \text { Early Voluntary }+\beta_{2} \text { Late Voluntary }+\beta_{3} \text { Early Voluntary* } \\
& \text { Mandatory }+\beta_{4} \text { Late Voluntary*Mandatory }+\beta_{5} \text { First-Time Mandatory } \\
& +\sum \beta_{j} \text { Controls }_{j}+\varepsilon
\end{aligned}
$$

where EconCon stands for the liquidity, cost of capital, and Tobin's q proxies and Controls $s_{j}$ denotes our set of control variables including the various fixed effects. To estimate this model, we obtain financial data from Worldscope, price and trading volume data from Datastream, and analyst forecasts and share price data for the cost of capital estimation from I/B/E/S.

\subsection{SAMPLE DESCRIPTION}

The sample used in the firm-year analyses covers all firms with fiscal years ending on or after January 1, 2001, through December 31, 2005. We start in 2001 to ensure that the sample period before the IFRS mandate is sufficiently long, so that we can also check for the potential anticipation of the pending rule change. ${ }^{19}$ Due to data availability at the time of our analysis, our sample ends in 2005. Thus, for the majority of countries, the mandatory IFRS observations in our sample stem exclusively from December fiscal year-end firms. Firms that have to adopt IFRS for the first time in fiscal years ending after 2005 are included as control firms, i.e., coded as local GAAP firms in 2005. As the firm-year analysis does not cover all firms in a country that have to adopt IFRS for the first time, it should be viewed as providing early evidence on the economic consequences of the IFRS

19 We also conduct analyses extending the sample period as far back as 1990. While the estimated effects become weaker and sometimes even flip in sign, the general tenor of our results does not change. However, these analyses highlight that the effects (or at least their magnitudes) are somewhat sensitive to the choice of the benchmark period. 
mandate. We overcome this data limitation in the country-month analysis where we cover all mandatory adopters and analyze the effects over the entire initial adoption year.

We begin the sample collection procedure with all firms from countries that require IFRS reporting and for which we have the necessary data to compute the variables used in the firm-year regressions described above. This yields a maximum treatment sample of about 35,000 firm-years from 9,000 unique firms, of which more than 3,100 must adopt IFRS for the first time. Table 1, Panel A, provides a break-down of the number of observations, the accounting standards followed, listing status and stock index membership for the IFRS adopting countries in our sample. ${ }^{20}$ About $11 \%$ of the firm-year observations stem from mandatory IFRS adopters. The group of voluntary adopters is smaller, comprising only $7 \%$ (early voluntary) or $2 \%$ (late voluntary) of the treatment sample, and the adoption rates vary substantially across countries.

Next, we augment the treatment sample with local GAAP firms from countries that do not require mandatory IFRS reporting. Panel B of Table 1 presents descriptive information on this benchmark sample representing about 17,000 unique firms and 71,000 firm-year observations from 25 countries. To the extent that there are voluntary IFRS adopters in these countries, we exclude them from the sample. We use three different benchmarks: (1) a maximum of 150 randomly selected firms per country (as indicated in column four of the panel), (2) U.S. firms only and (3) the entire worldwide benchmark sample. While the U.S. or the Worldscope universe are natural benchmarks, we primarily report results using the random sample as this approach reduces the potentially undue weight of observations from a small set of countries (e.g., Japan) and diversifies contemporaneous changes in benchmark countries. For instance, it is possible that benchmark countries have regulatory changes

20 The descriptive information presented in Tables 1 and 2 is based on the least restrictive specification, i.e., Model 3 for Zero Returns in Table 4, Panel B, using the complete worldwide sample as a benchmark. 
themselves that coincide with IFRS adoption in treatment countries. Such a concern exists with regard to the U.S. and the implementation of the Sarbanes-Oxley Act of 2002.

Panel C of Table 1 reports the sample composition by year. Out of the 19,726 observations in 2005, the year IFRS reporting becomes mandatory in all treatment sample countries but Singapore, $2.4 \%$ are from early voluntary adopters, $0.9 \%$ from late voluntary adopters and $16.0 \%$ from firms that are forced to adopt IFRS for the first time. The remaining firms are from our benchmark sample.

Table 2, Panel A, presents descriptive statistics on the dependent variables used in the firm-year analyses. For the average sample firm, $29.2 \%$ of daily stock returns are equal to zero, indicating days with no trades or no changes in closing prices. The mean (median) price impact metric is $4.84(0.22)$ suggesting that, on average, a US\$ 1,000 trade moves stock price by $0.48 \%(0.02 \%)$. The difference between the mean and median illustrates that this variable is highly skewed. The mean total trading costs amount to $6.5 \%$ of price, while the mean bid-ask spread equals $3.3 \%$. The mean cost of capital is $10.2 \%$ while the mean Tobin's q is 1.4 . All these values are in plausible ranges. Panel B reports descriptive statistics on the continuous independent variables. Except for variables with natural lower and upper bounds, we truncate all variables at the first and $99^{\text {th }}$ percentile.

\subsection{EMPIRICAL RESULTS}

\subsubsection{Difference-in-Differences Analyses}

We begin our analysis with univariate comparisons of the liquidity, cost of capital, and valuation effects around the introduction of mandatory IFRS reporting using a difference-in-differences design. This is a simple way to account for unobserved differences between treatment and control firms and to adjust observed changes for the treatment firms by concurrent changes that are also experienced by the control firms. Specifically, we compute the difference in our outcome variables between IFRS adopters and non-adopting, local GAAP benchmark firms in the year before and in the year when 
mandatory IFRS reporting begins and then compare the relative change over time. ${ }^{21}$ To eliminate the impact of sample composition, we require each firm to have data in both years.

Table 3 reports mean values of the dependent variables across mandatory IFRS adopters and a benchmark sample of non-IFRS adopters for the fiscal years 2004 and 2005. The four liquidity proxies provide a consistent picture. Liquidity is higher in IFRS adoption countries to begin with, but this gap increases in the year of the mandatory change. For instance, based on a sample of 2,696 mandatory IFRS adopters, the mean proportion of zero return days in the pre-adoption period is $31.2 \%$ and decreases to $27.7 \%$ in 2005 . Over the same period, the 3,987 benchmark firms also experience a decline in zero return days from $35.2 \%$ to $33.8 \%$. However, the decrease in zero-return days is significantly larger (by $2.1 \%$ ) for the IFRS adopters than for the benchmark firms, using ttests that compare means of yearly firm-level changes across the two groups.

The cost of capital increases for IFRS adopters relative to the benchmark firms around the introduction of the mandate (by 35 basis points) and this difference is statistically significant. Tobin's q slightly increases for both mandatory IFRS adopters and benchmark firms, but the difference in the differences is not statistically significant. Thus, the cost of capital and Tobin's q results do not mirror the liquidity analyses, i.e., do not produce evidence of significant capital-market benefits. One potential explanation is that both the cost of capital and equity valuations are more susceptible to anticipation effects. We investigate this issue in our regression analyses below.

\subsubsection{Analyses of Liquidity Effects}

In Table 4, we report regression results. Throughout the firm-year analyses we tabulate OLS coefficient estimates and, in parentheses, t-statistics based on robust standard errors that are clustered

21 Throughout the paper, we report results using a set of randomly selected firms around the world as benchmark. However, we explicitly assess the sensitivity of our findings to the choice of benchmark firms (see Table 4, Panel B). 
by firm. $^{22}$ Panel A presents results for the four liquidity measures as well as the liquidity factor using the random sample of local GAAP firms from non-adopting countries as benchmark. Except for the positive but insignificant coefficients on First-Time Mandatory in the price impact regression and on Late Voluntary*Mandatory in the bid-ask spread regression, the coefficients of primary interest (highlighted in bold) are all negative and, in most cases, significant. ${ }^{23}$ These results indicate that all firms reporting under IFRS experience a significant increase in market liquidity in the year of the IFRS mandate.

However, the magnitude of the effects differs across firms. Firms that were forced to adopt IFRS generally experience the smallest increase, while voluntary adopters see larger liquidity effects, either when they switch to IFRS ahead of the mandatory change (late voluntary) or in the year of the mandate (early voluntary). For instance, the coefficient estimate of -2.99 on First-Time Mandatory in column 3 suggests that the total trading costs of mandatory IFRS adopters decrease by 12 basis points, which amounts to a $3 \%$ improvement relative to the pre-adoption median of $4.23 \%$ (or 423 basis points). At the same time, trading costs for late voluntary adopters go down by 34 basis points even though they have already decreased by 47 basis points when the firm initially switched to IFRS ahead of the mandate. Early voluntary adopters do not experience a significant liquidity change upon IFRS adoption, but experience a reduction in total trading cost by 61 basis points in the year IFRS

22 As the IFRS adoption decision is made at the country level, clustering at the firm level might overstate statistical significance. One alternative is to cluster observations at the country-industry level, which allows for correlation across time but is more conservative than firm-level clustering as it also allows firms in the same country and industry to be similarly affected by the IFRS mandate. Unreported sensitivity analyses show that clustering standard errors at the country-industry level produces weaker, but still significant results. One could also cluster at the country level, which is obviously very conservative and, not surprisingly, yields generally insignificant results. In Section 5, we provide an alternative analysis at the country level, which also addresses the issue of cross-correlation.

23 Moreover, the First-Time Mandatory coefficient is negative and close to conventional significance levels in the price impact regression when we use only U.S. firms in our benchmark sample. Stronger truncation of price impact also slightly improves the results for this variable, pointing to measurement error as another cause for its insignificance. 
reporting becomes mandatory. ${ }^{24}$ The economic magnitudes of the effects for first-time mandatory adopters fall into a similar range for the proportion of zero-return days and the bid-ask spreads. The former (latter) decreases by 100 (12) basis points or about 4\% (6\%) based on the pre-adoption median of $27 \%(1.94 \%)$. In the last column of Panel A, we find similar results using the Liquidity Factor as a summary measure. The main control variables, i.e., firm size, share turnover, volatility and the market benchmark, are generally highly significant across all columns. ${ }^{25}$

The sizeable liquidity benefits for late voluntary adopters around their switch to IFRS have to be interpreted carefully as they are likely affected by selection effects. For instance, firms that adopt IFRS ahead of the mandate could signal a strong commitment to transparency and it could be that investors respond to this signal and the commitment to transparency, rather than the adoption of IFRS per se. More interestingly, early voluntary adopters experience liquidity improvements when IFRS reporting becomes mandatory and, in several cases, these increases are even larger than the liquidity changes of the mandatory adopters. Thus, mandatory adopters do not gain in liquidity relative to voluntary adopters. The liquidity effects for the early voluntary adopters cannot be explained with a switch in the reporting standards, as they already report under IFRS. They are also not driven by the fact that we code countries' actual adoption of mandatory IFRS reporting, rather than the earlier announcements of plans to do so. That is, when we additionally include an indicator variable marking the period between the announcement and the adoption dates of IFRS, the results are similar. As discussed in Section 2, the liquidity benefits for voluntary adopters when the mandate takes effect could have multiple sources. They could stem from comparability benefits when other firms in the

24 We compute the level of the total trading costs after the switch to IFRS and the mandate as $e^{\ln (0.0423)-0.0299}=0.0411$ (or 411 basis points) for mandatory adopters, $e^{\ln (0.0423)+0.0075}=0.0426$ and $e^{\ln (0.0423)+0.0075-0.1554}=0.0365$ for early voluntary, and $e^{\ln (0.0423)-0.1184}=0.0376$ and $e^{\ln (0.0423)-0.1184-0.0931}=0.0342$ for late voluntary adopters, respectively.

25 The insignificance of the U.S. listing indicator in most of our regressions may seem surprising in light of prior findings in the cross-listing literature (e.g., Doidge, Karolyi, and Stulz [2004], Hail and Leuz [2008]). Note, however, that our control sample includes U.S. firms, our coding combines exchange and OTC listings, and that the treatment sample contains many cross-listed firms from the EU, which are expected to have weaker, if any, bonding effects. Hence, our estimate for the U.S. listing indicator should not be compared to estimates in cross-listing work. 
economy are forced to adopt IFRS. Alternatively, they could reflect concurrent changes in the institutional environments of IFRS-adopting countries, which would affect both voluntary and mandatory adopters. Finally, they could result from firms' reporting improvements around the IFRS mandate, as many voluntary adopters, especially the early ones, initially did not provide full IFRS reports and often started with dual reporting strategies (e.g., Daske et al. [2007]). We investigate these issues in the cross-sectional analyses.

In Panel B of Table 4, we assess the sensitivity of the liquidity results to various research design choices. We report these analyses for the proportion of zero-return days, total trading costs and the Liquidity Factor. ${ }^{26}$ In Model 1, we limit the sample to IFRS adoption countries. Hence, the liquidity effects for mandatory IFRS adopters are evaluated relative to firms that have not yet switched to IFRS by the end of 2005. In this case, the coefficients for our variables of interest are largely insignificant. We then vary our benchmark sample using either U.S. firms only (Model 2) or the entire Worldscope population (Model 3). While the choice of benchmark sample does not seem to matter for the zero-returns metric, the results for the total trading costs and the liquidity factor are weaker than in Panel A, in particular when using U.S. firms as a benchmark. The variability of the results in Models 1 to 3 and Panel A illustrates the importance of benchmarking and the choice of the benchmark. In Model 4, we control for changes in sample composition over time by holding the sample constant. The effects become slightly weaker, and for the liquidity factor, all three mandatory coefficients are even insignificant. As this specification tilts the sample towards larger more stable firms, some attenuation is expected. In Model 5, we limit the treatment sample to firms that have already switched to IFRS, i.e., we exclude firms from IFRS-adopting countries that have not yet adopted the new standards. Including these firms could work against finding significant effects if

26 We also run (but do not tabulate) the sensitivity analyses for the remaining two liquidity measures. Except for Model 1 , the results for price impact are at least as good as the base model results in Panel A, while the results for the bidask spreads are slightly weaker. 
markets (partially) anticipate the liquidity consequences of the IFRS mandate. Moreover, if there are concurrent changes in the institutional framework that benefit the liquidity of all firms in the economy, removing these firms should increase the effects. Consistent with these two explanations, the results for Model 5 are substantially stronger, both in terms of significance and magnitude than in Panel A. However, the rank order of the coefficients and our inferences remain the same. Finally, in Model 6, we replace the firm-fixed effects by country-fixed effects, and, again, find similar results.

\subsubsection{Analyses of Cost of Capital and Valuation Effects}

Table 5 presents the results of the cost of capital and valuation analyses. We start with the base specification (Model 1) and, consistent with the difference-in-differences results, find a significant increase in cost of capital for firms that were forced to adopt IFRS. However, our estimation of the implied cost of capital might suffer from anticipation effects. For instance, if IFRS in fact lower the cost of capital and, as a result, investors use a lower rate to discount expected future cash flows that occur after IFRS adoption, the valuation models produce a lower implied cost of capital estimate even for pre-IFRS years because they assume a constant cost of capital. Thus, anticipation effects may make it harder to detect a reduction in the cost of capital. We address this issue by (i) excluding firm-year observations immediately before mandatory IFRS adoption (Model 2), and (ii) by moving the mandatory IFRS indicator variables by one year, i.e., we start coding them as one in the year before the official IFRS adoption date (Model 3). These tests also mitigate concerns about first-time IFRS interim reporting, press releases and other disclosures ahead of the accounting change, all of which would likely accelerate the capital-market effects (if IFRS reporting has an effect).

Consistent with the existence of anticipation effects, we find that the coefficients on the mandatory IFRS variables move in the expected direction in Model 2 and become significantly 
negative in Model 3. ${ }^{27}$ Even the relative magnitude of the effects for the three adopter types around the mandate is now consistent with the liquidity results. Mandatory adopters experience a decrease in the cost of capital by 26 basis points, which is a $2.5 \%$ decline relative to the pre-adoption median cost of capital. Early voluntary adopters and late voluntary adopters experience declines in their cost of capital by 66 and 90 basis points, respectively. ${ }^{28}$

In the second half of Table 5, we report the Tobin's q results across three similar specifications. Tobin's q captures not only changes in firms' cost of capital but also real effects on investment and growth and IFRS-related costs (e.g., implementation costs). In addition, it does not rely on analyst forecasts, which could be substantially affected by the switch to a different accounting regime. We find that in the year of the regulatory change mandatory adopters and late voluntary adopters exhibit a significant decrease in firm value compared to the random sample of benchmark firms. Similar to the cost of capital results, the coefficients on the three mandatory IFRS variables increase as we move from Models 1 to 3, and they become significantly positive for mandatory and early voluntary adopters in Model 3. For mandatory adopters, the effect amounts to $7.1 \%$ of the pre-IFRS median q, which is surprisingly large. One reason for this finding could be that the measurement of Tobin's q is mechanically affected by the change in accounting rules around the switch to IFRS. Hung and Subramanyam [2007] provide evidence for German firms that the switch to IFRS, on average, increases the book value of equity and total assets, which would lead to a downward bias in the $\mathrm{q}$ effects. However, these transition effects likely differ across firms and countries and could also go in

27 The liquidity proxies are expected to be less prone to anticipation effects (because investors worry about adverse selection mainly when they trade). However, when we repeat these tests for liquidity (not tabulated), we find some evidence of anticipation, but the effects are not as strong as for the cost of capital. This is expected given that we compute the liquidity proxies from month -5 to +7 to account for IFRS interim reporting (see Appendix).

28 In addition, we conduct the following sensitivity tests. First, for the subset of voluntary IFRS firms, we include only the first two years after the voluntary switch to IFRS in order to assess the existence and direction of temporary transition effects. Second, to gauge the impact of extreme forecasting errors due to the change of accounting standards, we exclude firms in the top and bottom $10 \%$ of the analyst forecast error distribution in the year of the mandated adoption from the group of IFRS firms. In both cases, the cost of capital results are very similar to those reported and the inferences remain unchanged. This also holds for our other dependent variables. 
the other direction (e.g., Capkun et al. [2008]). ${ }^{29}$ Hence, the magnitude of the Tobin's q effects should be interpreted cautiously.

Overall, the results for the cost of capital and Tobin's q are consistent with each other, and they are in line with our liquidity findings once we control for anticipation.

\section{Heterogeneity in the Capital-Market Effects around the IFRS Mandate}

\subsection{RESEARCH DESIGN}

In our second set of empirical tests, still employing the firm-year design, we examine the crosssectional variation in the capital-market effects around IFRS reporting. We sequentially partition IFRS firm-year observations by countries' institutional frameworks using the following country-level factors: (i) the rule of law in the year 2005, drawn from Kaufmann, Kraay, and Mastruzzi [2007]. Higher values represent countries with stricter enforcement regimes. (ii) We distinguish between EU member states and the remaining IFRS adoption countries. Apart from providing descriptive evidence for the largest economic bloc of countries requiring IFRS reporting, this partition also identifies a set of countries for which enforcement regimes have been significantly revised around the adoption of mandatory IFRS reporting (see Section 2 and also Hail and Leuz [2007]). (iii) We use the opaqueness of financial reporting practices in a country, measured by the earnings management score from Leuz, Nanda, and Wysocki [2003], as a proxy for the strength of firms' reporting incentives in a given country (and hence the likely responsiveness to the IFRS mandate). We multiply this measure by minus one so that higher values indicate less opaque earnings. (iv) To capture the degree to which the accounting rules change with the switch to IFRS, we use the Bae, Tan, and Welker [2008] summary score of how local GAAP differ from IAS on 21 key accounting

29 The time-incongruent measurement of the numerator of Tobin's q (at month +7 ) and the denominator (at the fiscalyear end) could also bias the effects across firms. When we measure Tobin's q congruently at the fiscal-year end, we obtain significantly positive valuation effects even in Model 1, which is again consistent with anticipation. For consistency with the other capital-market variables, however, we measure (the numerator of) Tobin's $q$ at month +7 . 
dimensions. Higher scores represent more differences. (v) We single out countries with an official convergence strategy toward IFRS reporting before it became mandatory. ${ }^{30}$

One concern about country-level institutional variables is that they are all highly correlated and that some of them are outcomes of more fundamental qualities of countries' institutional frameworks. To address this concern, we orthogonalize earnings opaqueness and accounting discrepancies with respect to more fundamental country characteristics. That is, we first regress the raw values of proxies (iii) and (iv) on countries' legal origin (La Porta et al. [1998]) and the log transformed average GDP per capita (World Bank), and then use the residuals from those regressions to form partitions in the cross-sectional analyses. ${ }^{31}$

Finally, we use the proportion of firms voluntarily reporting under IFRS in a given industry to split the sample. The idea behind this partition is that voluntary adopters may experience comparability effects when other firms in the same industry must switch to IFRS. However, if many industry peers already report under IFRS, the comparability benefits (or externalities) from mandatory adopters are likely to be smaller. Thus, we analyze whether the effects for voluntary adopters in the year of IFRS mandate are inversely related to the number of global industry peers already reporting under IFRS.

For our cross-sectional analyses, we combine the early and late voluntary adopters into a single group to ensure that we have a sufficient number of observations in each of the bins created by our partitions. That is, we create two indicator variables, Voluntary and Voluntary*Mandatory, marking

30 As many countries have been converging toward IAS/IFRS one way or another in recent years (e.g., by integrating IFRS solutions into domestic GAAP, by wholesale adoptions of individual IFRS standards, etc.), we code only official convergence strategies, i.e., cases where local regulators had officially announced to gradually move towards IFRS over a predetermined timeframe.

31 Proxy (i), legal enforcement (measured as rule of law), is more likely to be a fundamental element, which is why we do not orthogonalize it. However, if we do so and then partition the sample based on the residuals, the crosssectional results are very similar to those reported below (using raw values). 
the entire series of IFRS observations and the fiscal years ending on or after the mandated change, respectively. We then transform the continuous institutional factors into binary variables splitting by the country or industry medians of the treatment sample. We interact these binary Conditional Variables with each of the IFRS indicators leading to the following empirical model:

$$
\begin{aligned}
\text { EconCon }= & \alpha_{0}+\alpha_{1} \text { Voluntary }+\alpha_{2} \text { Voluntary } * \text { Conditional Variable }+\alpha_{3} \text { Voluntary* } \\
& \text { Mandatory }+\alpha_{4} \text { Voluntary*Mandatory } * \text { Conditional Variable }+\alpha_{5} \text { First }- \\
& \text { Time Mandatory }+\alpha_{6} \text { First-Time Mandatory }{ }^{*} \text { Conditional Variable } \\
& +\sum \alpha_{j} \text { Control }_{j}+v
\end{aligned}
$$

Relative to equation (1), the interpretation of the coefficients on Voluntary, Voluntary*Mandatory, and First-Time Mandatory does not change except that it applies only to IFRS adopters where the conditional variable is below the median. The interaction terms represent the incremental capital-market effects for firms from countries and industries where the conditional variable is above the median. To gauge the total effects for those latter firms, we must sum the two corresponding coefficients. The control variables and fixed effects are the same as before.

\subsection{EMPIRICAL RESULTS}

Table 6, Panel A, presents descriptive information on the institutional variables by country (together with the official IFRS announcement and adoption dates). Next to the raw values or, in the case of the earnings management and accounting differences scores, the residuals from a first-stage regression on legal origin and GDP, we present (in parentheses) the binary indicator values used to partition the treatment sample countries. In Panel B, we report the percentages of firms voluntarily reporting under IFRS in a given industry in the year before the mandate.

The sample used in the cross-sectional analyses is the same as in Section 3. For brevity, we tabulate and discuss only the results estimating equation (2) for the Liquidity Factor. However, the results using the four individual liquidity proxies are very similar to those reported below and the 
inferences are essentially the same. The cross-sectional results for the cost of capital (using Model 3) are weaker in the sense that the differential effects are not always significant, but they point in the same direction. The cross-sectional results for Tobin's q are in line with liquidity for the rule of law, earnings opaqueness and convergence strategy partitions, but insignificant or opposite otherwise.

In Table 7, we report the coefficient estimates for the IFRS adopter type variables. In addition, we indicate the statistical significance of the joint coefficients ( $p$-values from Wald tests). As Model 1 shows, the liquidity benefits around the introduction of IFRS occur only in countries with a relatively strong rule of law. ${ }^{32}$ That is, the interaction terms for voluntary and mandatory adopters are negative and highly significant for the strong enforcement group, but no such effects exist in countries with weak legal enforcement. This result is plausible as the IFRS mandate is unlikely to have much of an effect if legal enforcement is weak. Partitioning by EU member states yields similar results (Model 2). Aside from relatively strong legal systems in EU countries, this result may reflect recent efforts to tighten enforcement, corporate governance, and auditor oversight. We also examine the differential effects for firms that already face strict enforcement regime because they are crosslisted on a U.S. exchange and subject to SEC oversight (results not tabulated). Although the sample of exchange-traded ADRs in IFRS-adopting countries is small, the results are as expected if enforcement changes play an important role. We find that, compared to the remaining IFRS firms, IFRS adopters that are cross-listed on U.S. exchanges experience lower, if any, liquidity benefits.

Next, we partition the sample by firms' reporting incentives. The idea is that firms operating in institutional environments that provide strong reporting incentives are likely to be more responsive to the IFRS mandate. In Model 3, we use the transparency of firms' earnings (prior to IFRS adoption) as a proxy for these reporting incentives. We find that the liquidity effects around IFRS adoption are

32 Results are qualitatively similar when we use the mean score across three enforcement variables drawn from La Porta et al. [1998], i.e., the efficiency of the judicial system, the rule of law, and the corruption index, instead of the Kaufmann, Kraay, and Mastruzzi [2007] rule of law variable in 2005 to partition the sample. 
larger and in fact only present in countries where earnings are relatively transparent in the first place. A split of IFRS adoption countries by ownership concentration, an alternative incentives proxy, yields similar results (not tabulated). These findings indicate that the documented capital-market benefits require more than the adoption of high-quality accounting standards; they need supporting institutions. Concurrent changes in these institutions could also explain why voluntary adopters experience larger effects around the IFRS mandate than firms that are forced to adopt IFRS.

The next two models examine the role of accounting differences between local GAAP and IFRS. The results for Models 4 and 5 are fairly similar. Both models suggest that mandatory and voluntary adopters exhibit larger increases in liquidity around the IFRS mandate if the differences between local GAAP and IFRS (or IAS) are larger. At face value, these results suggest that the differences in the accounting standards matter. However, accounting differences are likely to matter most if the rules are properly enforced and firms do not have countervailing incentives (e.g., Hope [2003], Burgstahler, Hail, and Leuz [2006]). To explore this issue, we further single out the group of IFRS adoption countries where not only local GAAP differ substantially from IFRS but also enforcement regimes or reporting incentives are strong. That is, we compare the effects in IFRS adopting countries with stronger rule of law (or more transparent earnings) and larger accounting discrepancies against the effects for the rest of the IFRS sample. Results (not tabulated) show that, as expected, liquidity increases the most for the former group, suggesting that change in the standards could play a role, but only when coupled with proper reporting incentives and legal enforcement.

Finally, in Model 6, we attempt to analyze potential comparability and global convergence benefits from IFRS reporting. Consistent with the notion that voluntary adopters should experience fewer positive externalities from the IFRS mandate when more of their peers already report under IFRS, we find a positive coefficient on the interaction between Voluntary*Mandatory and the partitioning variable for industries with a higher fraction of IFRS firms. However, as the coefficient 
is statistically insignificant, we are unable to provide evidence supporting the notion of comparability effects. The interpretation of the significantly positive incremental coefficient for mandatory adopters in industries with high voluntary adoption rates is less straightforward because there is no clear prediction. From a comparability standpoint, one would expect mandatory adopters to benefit more when there are already many peers reporting under IFRS, yielding an opposite prediction, i.e., a negative interaction. On the other hand, it is possible that the switch to IFRS is rewarded less in the market place when there are already many industry peers reporting under IFRS, suggesting weaker effects and hence a positive interaction.

Taken together, the cross-sectional analyses show that the capital-market effects are heterogeneous across countries in a way that is consistent with the reporting incentives view in the international accounting literature.

\section{Country-Month Analyses of the Liquidity Effects around the IFRS Mandate}

\subsection{RESEARCH DESIGN}

Our third and final set of tests pursues a different empirical strategy to identify the capital-market effects around the introduction of mandatory IFRS reporting. Instead of comparing firm-year observations across IFRS and non-IFRS adopting firms, we use the fact that the IFRS mandate applies to firms at different points in time depending on their fiscal-year end. In other words, this approach exploits the gradual adoption of the new reporting regime during the initial year of mandatory IFRS reporting, as given by countries' fiscal-year end pattern. This adoption pattern is largely exogenous once a country sets the initial date for IFRS adoption. If there are discernable capital-market effects from the IFRS mandate, we expect changes in market liquidity to mirror countries' adoption patterns. That is, liquidity should decrease as more firms start reporting under IFRS. As this approach is tied to the phase-in of IFRS and the availability of IFRS financial reports, 
it should not pick up one-time shocks or time trends in liquidity in IFRS adoption countries, which could affect the firm-year analyses. It is also more likely to capture the effects of mandatory IFRS reporting and less likely to reflect other institutional changes (e.g., in the governance or enforcement regimes) that take place in the year of the IFRS mandate. Of course, if these supporting changes in the countries' infrastructure operate primarily through firms' financial reports, e.g., in making IFRS reports more credible, then the capital-market effects of the other institutional changes should exhibit a similar time pattern as the IFRS effects and hence cannot be separated from each other.

We analyze liquidity changes at the aggregate, i.e., country-month level. The reasoning behind this design choice is that, by aggregating firms in a country and examining aggregate liquidity changes, we are more likely to also capture any externalities that adopting firms confer on firms that have already adopted or will soon adopt IFRS (e.g., due to better comparability). The country-month approach also addresses concerns about potential cross-sectional correlation in the error terms due to the fact that all firms in a given country are subject to the same mandate.

We relate aggregate changes in market liquidity to a variable tracking countries' IFRS adoption patterns at the monthly level. We define $\triangle$ IFRS Adoption Rate as the month-to-month change in the cumulative proportion of firms in a given country that are required to follow IFRS for the first time. We assign firms to a given month in two ways. Our first approach relies on firms' fiscal year ends (FYE) and assumes that financial statement information becomes available with a three-month time lag. ${ }^{33}$ That is, in computing the cumulative adoption rate, we assign the value of 1 to each month starting in month $m=F Y E+3$, and zero otherwise. For instance, if a firm's fiscal year ends on April $30^{\text {th }}$, we assume the financial information is made available in July. We then sum all the firm-level

33 Note that for our tests to work, we do not necessarily require the full annual reports to be available by this date, but that firms have released at least some financial information under the new reporting regime (e.g., IFRS earnings), allowing market participants to update their priors. In most markets, however, firms are required to publish their annual reports within three months of their fiscal year end. 
values in a given country and month, and divide it by the total number of firms switching to IFRS over the entire year. We label this variable $\triangle$ IFRS Adoption Rate $_{F Y E}$.

Our second approach accounts for the fact that many adopting countries require some form of IFRS interim reporting in the year leading up to the first annual IFRS financial statements (see IFRS 1 and IAS 34). Interim reporting likely weakens the power of tests that are centered on the release of annual information. Moreover, it is likely that a uniform three-month time lag does not accurately reflect firms' reporting practices. We therefore apply the following two refinements to create $\triangle$ IFRS

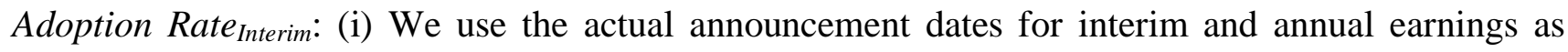
reported in $\mathrm{I} / \mathrm{B} / \mathrm{E} / \mathrm{S}$ to assign firms to a given month. If this data is missing, we first determine whether local rules require quarterly or semi-annual reporting (using LexisNexis and websites of national stock exchanges), and then, based on this classification, allow two months for interim information to be distributed. We again apply the FYE+3 convention for the annual report without I/B/E/S announcement dates. (ii) Once the dates of interim and annual reporting have been defined, we account for interim reporting by adding $0.25(0.5)$ to the adoption rate in the release month of each quarterly (semi-annual) report, and again assign a value of 1 for the annual report. Thus, the cumulative adoption rate for a single firm that reports quarterly takes on the values of $0.25,0.5,0.75$ and 2 after the disclosure of the first, second, third, fourth quarter and annual reports, respectively. This coding assumes that firms jointly release fourth quarter (or second half-year) financial information and the annual report. That is, a firm reporting semi-annual earnings in September and annual earnings in March of the following year is coded as '0' until September, '0.5' from October to March, and '2' starting in April.

The difference between our two coding approaches is that the FYE adoption rate relies purely on firms' fiscal-year ends whereas the Interim adoption rate relies on actual announcement dates from I/B/E/S, whenever available, and it accounts for the early release of IFRS information through 
interim reports. ${ }^{34}$ These two refinements are potentially important as the country-month analysis relies heavily on identifying when the new IFRS financial statements are released to the market.

We use Zero Returns, Price Impact and the Bid-Ask Spread as dependent variables, each computed at the firm level in a given month (see the Appendix). ${ }^{35}$ We aggregate the liquidity measures in a country and month by taking medians and then compute monthly changes. Similar to the firm-year analyses, we control for general (and worldwide) trends in the market proxies by including the contemporaneous change $(\Delta)$ in a Market Benchmark, based on monthly median changes in liquidity for a random sample of up to 150 firms per non-IFRS adopting country. As we cannot include firm-level controls in this analysis and, hence, the idiosyncrasies of a single random draw are larger, we repeat this procedure 100 times and use the resulting average values in the analyses. In addition, we include lagged changes of the dependent variable from the same calendar month one year ago to account for seasonal patterns. For instance, aggregate market liquidity could be higher (lower) just after (before) most firms in a country have reported their annual reports. Because liquidity is likely to be correlated over time, we also include the lagged level of the dependent variable. Apart from country-fixed effects, we further control for firm size and return variability at the market level (as defined in the notes to Table 8). We measure all lagged variables as of month $m$-12. This design leads to the following empirical model, where $\Delta$ EconCon refers to the three liquidity measures:

$$
\Delta \text { EconCon }_{m}=\delta_{0}+\delta_{l} \Delta \text { IFRS Adoption Rate }_{\text {FYE or Interim, } m}+\sum \delta_{j} \text { Controls }_{j}+\mu
$$

34 annual information based solely on the fiscal-year ends. These results (untabulated) are generally consistent with
those reported in Table 8 (i.e., they suggest a weak increase in liquidity around the adoption dates). 35 Due to data restrictions, we are unable to conduct the country-month analysis using implied cost of capital and Tobin's q as dependent variables. Also, we cannot compute total trading costs on a monthly basis because longer return time-series are necessary for proper estimation. 


\subsection{SAMPLE DESCRIPTION AND EMPIRICAL RESULTS}

The sample window for the country-month analysis covers a 15-month period (i.e., January 2006 to March 2007, except for Singapore where we use January 2004 to March 2005) during which the first mandatory IFRS annual reports are released. When we account for interim reporting, we include the 12 months leading up to the first full set of financial statements under IFRS and extend the window to 27 months (i.e., January 2005 to March 2007). To capture the effects around the IFRS mandate on firms that are forced to adopt IFRS, we include only firms that report under IFRS for the first time, i.e., we exclude voluntary adopters from the aggregate liquidity measures. The sample using annual reporting consists of 360 country-month observations from 26 countries. Allowing for interim reporting, the sample increases to a maximum of 656 country-month observations.

Table 8, Panel A, reports descriptive statistics for the dependent and independent variables. The mean and median monthly changes in the liquidity metrics are either zero or slightly negative, suggesting that there is no clear trend in liquidity. The same is true for the market benchmarks, which are based on 100 random samples of non-IFRS adopting countries. ${ }^{36}$ The average change in the IFRS Adoption Rate FYE $_{\text {equals }} 6.7 \%$. However, the distribution is highly skewed, and there are many months with only very small changes in the cumulative adoption rate. The reason is that, in many countries, fiscal-year ends cluster in December, March, June or September. The distribution is slightly less skewed when we compute the changes in the IFRS Adoption Rate Interim $_{\text {because this }}$ variable accounts for variation in firms' earnings announcement dates.

Panel B of Table 8 presents coefficients from estimating equation (3) together with robust tstatistics. For each dependent variable, we report results for the $\triangle$ IFRS Adoption Rate variable based on the FYE+3 convention (Models 1 and 2) and the combination of interim and annual reporting

36 When we compute market benchmarks based on U.S. firms only or based on the entire Worldscope population, the results are similar, except for the spreads which are much weaker using the entire Worldscope population. 
(Model 3). In addition, in Models 2 and 3, we limit the sample to the months with the biggest changes in the IFRS adoption rate to increase the power of our tests. That is, we use only observations that belong to the top quartile of the adoption rate changes. The sample restriction is meant to address the issue that in many months the change in the adoption rate is very small or zero, while liquidity continues to fluctuate, which likely attenuates our coefficients.

The results across the three dependent variables are consistent in that all the coefficients on the $\triangle$ IFRS Adoption Rate variable are negative, suggesting a reduction in zero return days, the price impact of trades, and bid-ask spreads. However, the coefficients are often not statistically significant. For zero returns and spreads, the results are significant at the $10 \%$ level or better for Models 2 and 3 , i.e., for the samples that are restricted to the biggest changes. For price impact, Models 2 and 3 point in the right direction but the p-values are only around $26 \%$. Overall, these results suggest an increase in market liquidity around the phase-in of IFRS reporting.

In terms of economic magnitude, the results in the first three columns suggest that a $10 \%$ change in the adoption rate translates into a reduction between 7 and 31 basis points in the level of aggregate zero returns. This corresponds to a reduction of up to $1.1 \%$ from the mean aggregate zero-return days of $28 \%$. Aggregate price impact decreases up to $0.007 \%$ per US\$ 1,000 trade and bid-ask spreads decrease up to 2 basis points, representing a reduction of $1.8 \%$ and $1.2 \%$ compared with the mean aggregate level of 0.39 and $1.7 \%$, respectively.

While the significance levels and the magnitude of the effects are modest, also compared to the results in the firm-year analysis, it is important to recognize that, despite its conceptual appeal from an identification perspective, the country-month analysis is conservative and low in power for at least two reasons. First, the identification of the IFRS effects relies on a relatively small number of observations. Firms' fiscal-year ends are heavily clustered in time, which reduces the variation that can be used to identify the IFRS adoption effects. Consistent with this argument, the magnitude of 
the coefficient estimates on the $\triangle$ IFRS Adoption Rate is substantially larger when we limit the sample to the months with the biggest changes. Second, as we conduct the analysis in changes, it is important to correctly identify when the IFRS financial information is released to the market. This is not a trivial task considering that many firms provide IFRS interim reports and IFRS-related guidance ahead of their first IFRS annual report.

We conduct an array of robustness checks. First, we perform three tests to reduce the concern that our results still capture general liquidity effects unrelated to IFRS reporting: (i) we replicate our country-month analysis two years before the introduction of mandatory IFRS reporting. In these "placebo" analyses, our adoption rate variables are never significant. (ii) We drop observations from March 2006 to address the concern that the results are driven by a single calendar month, i.e., the month when all the December 2005 fiscal-year end firms likely report, and still obtain similar results. (iii) We compute aggregate liquidity only for firms in treatment countries that have that have not yet adopted IFRS in a given country and month to see whether the aggregate liquidity increase documented earlier is also present in these firms. We find little evidence that these firms experience liquidity increases, suggesting that our results stem primarily from firms switching to IFRS in the respective country and month.

Second, we use two- and three-month changes in liquidity and the adoption rate to address the difficulty of correctly identifying when the new IFRS financial information is released. Longer intervals reduce the likelihood of misclassifying the reporting month but also reduce the number of observations. The results using two- and three-month changes are generally consistent with (and in some cases stronger than) the findings in Table 8. That is, we find significant decreases in zero returns and spreads around the IFRS phase-in, but the results for price impact continue to be weak.

Finally, we perform several sensitivity tests regarding our empirical specification. We use a loglinear specification for the dependent variables (which is particularly important for price impact as 
this variable is highly skewed, even at the country-median level), introduce additional control variables (e.g., lagged turnover, changes in firm size and volatility), vary the variable measurement (e.g., use means instead of medians; use the mid-point of a month as cut-off for assigning earnings announcement dates to a particular month instead of the month end). These sensitivity checks produce similar results to those presented in Table 8, although the magnitude of the effects depends on the exact specification.

Taken together, the results for the country-month analysis corroborate the liquidity increase around the IFRS mandate as suggested by the firm-year analysis. However, liquidity effects in the country-month analysis are weaker in magnitude. As the latter analysis is more likely to identify pure IFRS reporting effects, the smaller magnitude is expected if the firm-year results are in part driven by concurrent changes in countries' institutional frameworks. Alternatively, the weaker results could simply reflect the difficulty of identifying the information release, which hurts the country-month analysis.

\section{Conclusion and Suggestions for Future Research}

The recent move towards IFRS in over 100 countries is one of the most significant regulatory changes in accounting history. The lessons and merits of this change are still debated and are a major policy issue. This paper contributes to this debate by providing early evidence on the capital-market effects of introducing mandatory IFRS reporting in 26 countries around the world. Aside from its policy relevance, the study provides rare evidence on the economic consequences of forcing firms to change an entire set of accounting and disclosure standards.

We analyze effects in stock market liquidity, cost of equity capital, and equity valuations using firm-year panel regressions with firm-fixed effects. We also perform country-month liquidity analyses that exploit countries' phase-in pattern during the initial year of IFRS adoption. Our results 
can be summarized as follows. We find that mandatory adopters experience statistically significant increases in market liquidity after IFRS reporting becomes mandatory. In our firm-year analyses, the effects range in magnitude from $3 \%$ to $6 \%$ for market liquidity relative to the levels prior to IFRS adoption. Consistent with the liquidity improvements, we also document a decrease in firms' cost of capital and a corresponding increase in Tobin's q, but only if we account for the possibility that these effects occur prior to the official IFRS adoption date. The latter suggests that the market anticipates the economic consequences of the mandate.

In interpreting these results, three additional sets of findings are worth noting. First, while the results are robust to numerous sensitivity checks, the magnitude and statistical significance of the documented effects varies substantially depending on the benchmark sample, the length of our sample period, and whether we include firms from IFRS-adopting countries with fiscal year ends other than December that have not yet switched to IFRS as a benchmark. The variation in the effects illustrates the difficulties of benchmarking the economic consequences of a regulatory change that simultaneously affects all firms in an economy.

Second, the aforementioned capital-market effects of mandatory (or forced) adopters are relative to local GAAP benchmark firms that are not required to adopt IFRS or have not yet switched. Firms that have already switched to IFRS voluntarily prior to the mandate are an alternative group against which one could benchmark the effects. We find that late voluntary adopters, i.e., firms that switch to IFRS reporting shortly before doing so becomes mandatory, experience positive liquidity and valuation effects. These effects are likely the result of self-selection and therefore not representative for the population of firms that is forced to adopt IFRS. More to the point, we document capitalmarket benefits for (early and late) voluntary adopters in the year of the mandated switch to IFRS. The magnitude of these benefits often exceed the corresponding effects for mandatory adopters, indicating that mandatory adopters do not gain in market liquidity or market value relative to 
voluntary adopters around the introduction of the IFRS mandate. As the latter group already reports under IFRS, one potential explanation for these capital-market effects is that mandatory adopters confer positive externalities on voluntary adopters by increasing the set of comparable firms, which in turn could lead to improved risk-sharing across a larger set of investors. We conduct tests for this explanation but obtain insignificant results. Another explanation for the effects of voluntary adopters around the IFRS mandate are concurrent changes in the institutional environment, e.g., with respect to enforcement, governance or auditing, which apply to all firms in the economy, including the voluntary adopters. Besides, voluntary adopters likely have better reporting incentives to begin with and, hence, should be more responsive to such institutional changes, which could explain stronger treatment effects. This explanation clearly questions the extent to which the capital-market effects for mandatory adopters can be attributed solely or even primarily to IFRS.

Third, and related to the last point, we analyze the cross-sectional variation in the effects for mandatory and voluntary adopters in an attempt to shed light on the factors driving the capital-market reactions. For both groups, we find that the capital-market benefits occur only in countries with relatively strict enforcement regimes and in countries where the institutional environment provides strong incentives to firms to be transparent. In the other IFRS adoption countries, market liquidity and firm value remain largely unchanged around the mandate. We also show that the effects around mandatory adoption are stronger in countries that have larger differences between local GAAP and IFRS and in countries without a prior convergence strategy towards IFRS. Although these latter results are consistent with the notion that differences in the accounting standards matter as well, further analysis shows that the effects are strongest for countries with large local GAAP/IFRS differences coupled with strong enforcement (or reporting incentives). Thus, the strength of enforcement regimes and firms' reporting incentives play a major role for our results. 
Taken as a whole, our evidence suggests modest but economically significant capital-market benefits around the introduction of mandatory IFRS reporting. However, as with many empirical studies that explore unchartered terrain, our study has a number of results that call for further investigation. For instance, while it seems clear that the documented capital-market effects cannot be attributed solely to the new reporting standards per se, it is still an open question which other factors do play a role. As several countries around the world have revised their enforcement and governance regimes to support the introduction of IFRS, we suggest that our results likely reflect the joint effects of these institutional changes and the IFRS mandate. Investigating this conjecture and the role of countries' enforcement regimes, which still differ considerably across IFRS countries, is an interesting avenue for future research.

Similarly, we point to comparability effects as a potential source for the capital-market effects, but are unable to provide statistical support for this explanation. Future research could explore this issue and the existence of positive externalities in more detail as well as examine whether IFRS are in fact implemented in ways that improve international comparisons. Furthermore, we suggest that the market's anticipation of economic consequences of the IFRS mandate as well as transitional effects around the first-time adoption could play a role in our results. For instance, we offer these effects as an explanation that reconciles the cost of capital and Tobin's q results with the liquidity findings. While it seems plausible that liquidity proxies are less subject to anticipation and transitional effects, this issue warrants further investigation. Finally, we note that our study is limited to a relatively short time period after the introduction of mandatory IFRS reporting. Thus, it remains to be seen whether the effects are sustained in the long run. 


\section{APPENDIX}

\section{Measurement of the Dependent Variables}

This appendix delineates the theoretical concepts, data sources and measurement of our six (three) dependent variables used in the firm-year (country-month) analyses. ${ }^{37}$ It also highlights some of the critical assumptions made during the empirical implementation.

\section{A.1. PROPORTION OF ZERO RETURN DAYS}

The first dependent variable is the proportion of zero daily returns out of the maximum potential trading days in a given year (or month in the country-month analyses). In the firm-year analysis, the measurement period spans month -5 through month +7 relative to the firm's fiscal-year end. We choose month +7 so that firms' annual reports are publicly available for a few months, which should enable markets to impound the IFRS effects. We begin our measurement before the fiscal year end (i.e., month -5) to account for leakage of information, IFRS-related communication by firms with investors during the transition period or first-time IFRS interim reporting, which often starts before the fiscal year end of the adoption year.

Lesmond, Ogden, and Trzcinka [1999] argue that zero-return days occur when the transaction costs of trading outweigh the value of new information not yet contained in prices and choose not to trade. The zero-return metric commonly serves as a proxy for illiquidity and has been validated in U.S. and international settings (e.g., Goyenko et al. [2006], Lesmond [2005], Bekaert, Harvey, and Lundblad [2007]). One advantage of this metric is its exclusive reliance on price data, which are more frequently available in an international setting than trading volume data. ${ }^{38}$

37 For parsimony, we combine the liquidity proxies (i.e., zero returns, price impact, total trading costs, and bid-ask spreads) by factor analysis with one oblique rotation. Liquidity Factor is the factor score from the first (and only) factor with an Eigenvalue greater than one.

38 That said, combining return and volume data to determine days with zero trade yields a proxy that is very highly correlated $(\rho \approx 0.9)$ with our measure based solely on returns. 


\section{A.2. PRICE IMPACT OF TRADES}

The second dependent variable is a measure of illiquidity suggested by Amihud [2002], which in turn is inspired by Kyle's [1985] lambda. The proxy is intended to capture the price impact of trades, i.e., the ability of an investor to trade in stock without moving its price. We measure illiquidity as the median daily price impact over the year (or month in the country-month analyses) and follow Amihud [2002] in computing price impact as the daily absolute price change in percent divided by US\$ trading volume (measured in thousands). Higher values indicate more illiquid stocks. To avoid the misclassification of days with no or low trading activity (i.e., days potentially yielding a price impact of zero), we omit zero-return days from the computation of the yearly or monthly medians. For expositional purposes we multiply the price impact metric by 1,000. Again, the measurement period starts in month -5 and runs through month +7 relative to the firm's fiscal-year end, for the reasons noted above. Price and volume data are gathered from Datastream.

\section{A.3. TOTAL TRADING COSTS}

The third dependent variable is a yearly estimate of the total roundtrip transaction costs implied by the trading behavior of investors, as developed by Lesmond, Ogden, and Trzcinka [1999]. It is based on the logic that informed investors do not trade when the cost of trading exceeds the value of new information. On those days, we expect a return of zero on the stock. Since private information is not observable and cannot be used to calculate the implied transaction cost, the model uses the information in the market return to make its inferences. The correct model for security returns is assumed to be the market model, but trades are constrained by transaction costs. Thus, firms' true returns will deviate from the measured returns in cases where the value of information is too low to justify trading given the transaction costs. This reasoning leads to the following relation between transaction costs and security returns. First, the relation between the true return and the market return follows the standard market model: 


$$
R_{j t}^{*}=\beta_{j}^{*} R_{m t}+\varepsilon_{j t}
$$

Second, the relation between the measured return, $R_{j t}$, and the true return, $R_{j t}^{*}$, on the security is described by the following system of equations:

$$
\begin{aligned}
& R_{j t}=R_{j t}^{*}-\alpha_{1 j}, \text { if } R_{j t}^{*}<\alpha_{1 j} \\
& R_{j t}=0, \text { if } \alpha_{1 j}<R_{j t}^{*}<\alpha_{2 j} \\
& R_{j t}=R_{j t}^{*}-\alpha_{2 j}, \text { if } R_{j t}^{*}>\alpha_{2 j}
\end{aligned}
$$

For firm $j$, the transaction cost threshold is $\alpha_{1 j}$ for trades on negative information and $\alpha_{2 j}$ for trades on positive information. The difference between the two thresholds, $\alpha_{2 j}-\alpha_{1 j}$, provides an estimate of the roundtrip transaction costs. Assuming daily returns are normally distributed, we then estimate the following log likelihood function for each firm and year using daily stock returns and equal-weighted local market index returns over the period from month -5 through month +7 relative to the firm's fiscal-year end:

$$
\begin{aligned}
& \ln L=\sum_{1} \ln \frac{1}{\left(2 \pi \sigma_{j}^{2}\right)^{1 / 2}}-\sum_{1} \frac{1}{2 \sigma_{j}^{2}}\left(R_{j t}+\alpha_{1 j}-\beta * R_{m t}\right)^{2} \\
& +\sum_{2} \ln \frac{1}{\left(2 \pi \sigma_{j}^{2}\right)^{1 / 2}}-\sum_{2} \frac{1}{2 \sigma_{j}^{2}}\left(R_{j t}+\alpha_{2 j}-\beta * R_{m t}\right)^{2} \\
& +\sum_{0} \ln \left(\Phi_{2}\left(\frac{\alpha_{2 j}-\beta_{j} * R_{m t}}{\sigma_{j}}\right)-\Phi_{1}\left(\frac{\alpha_{1 j}-\beta_{j} * R_{m t}}{\sigma_{j}}\right)\right)
\end{aligned}
$$

Stock prices and home country market index data are collected from Datastream. Following Lesmond [2005], we require at least 24 daily returns and $20 \%$ of the daily returns to be different from zero per firm-year observation. Our proxy of total trading costs equals the difference between the estimated coefficients $\alpha_{2 j}$ and $\alpha_{1 j}$. 


\section{A.4. BID-ASK SPREAD}

The fourth dependent variable is the bid-ask spread, which is a commonly used proxy for information asymmetry (e.g., Welker [1995], Healy, Hutton, and Palepu [1999], Leuz and Verrecchia, [2000]). We obtain the closing bid and ask prices for each day from Datastream and compute the daily quoted spread as the difference between the two prices divided by the mid-point. We then compute the median daily spread over the year (or month). The measurement period starts in month -5 and ends in month +7 relative to the firm's fiscal-year end.

\section{A.5. IMPLIED COST OF EQUITY CAPITAL}

As our fifth proxy, we use the implied cost of equity capital. Following Hail and Leuz [2006], we compute estimates of the implied cost of capital using four models suggested in the literature. All four models are consistent with discounted dividend valuation but rely on different earnings-based representations of this model. For each model, we substitute market price and analyst forecasts from $\mathrm{I} / \mathrm{B} / \mathrm{E} / \mathrm{S}$ into the valuation equation and back out the cost of capital as the internal rate of return that equates current stock price and the expected future sequence of residual incomes or abnormal earnings. We average over the four models to obtain a single estimate per firm-year observation. ${ }^{39}$ We recognize that implied cost of capital estimates could be problematic around changes in firms' accounting standards. First, the switch poses a challenge for the clean-surplus and terminal-growth assumptions of these models. Second, the switch may make it harder to financial analysts to forecast future earnings, at least for an initial period. We therefore rely on a series of alternative capitalmarket proxies to assess the cost of capital effects around the IFRS mandate.

The following table provides a short overview of the four valuation models used and outlines the model-specific assumptions:

39 Hail and Leuz [2008] explore alternative ways to aggregate the four proxies and find that these techniques have little impact on their results. We therefore use a simple average. 
Claus and Thomas [2001]:

$$
P_{t}=b v_{t}+\sum_{\tau=1}^{T} \frac{\left(\hat{x}_{t+\tau}-r_{C T} \cdot b v_{t+\tau-1}\right)}{\left(1+r_{C T}\right)^{t}}+\frac{\left(\hat{x}_{t+T}-r_{C T} \cdot b v_{t+T-1}\right)(1+g)}{\left(r_{C T}-g\right)\left(1+r_{C T}\right)^{T}}
$$

Model-specific assumptions:

This is a special case of the residual income valuation model. It uses actual book values per share and forecasted earnings per share up to five years ahead to derive the expected future residual income series. We define residual income as forecasted earnings per share less a cost of capital charge for beginning of fiscal year book value of equity per share. We assume clean surplus, i.e., future book values are imputed from current book values, forecasted earnings and dividends. Dividends are set equal to a constant fraction of forecasted earnings. At time $T=5$, it is assumed that (nominal) residual income grows at rate $g$ equal to the expected inflation. As a proxy for $g$, we use the (annualized) median of country-specific, one-year-ahead realized monthly inflation rates. Note that $g$ sets a lower bound to the cost of capital estimates.

Gebhardt, Lee, and Swaminathan [2001]:

$$
P_{t}=b v_{t}+\sum_{\tau=1}^{T} \frac{\left(\hat{x}_{t+\tau}-r_{G L S} \cdot b v_{t+\tau-1}\right)}{\left(1+r_{G L S}\right)^{t}}+\frac{\left(\hat{x}_{t+T+1}-r_{G L S} \cdot b v_{t+T}\right)}{r_{G L S}\left(1+r_{G L S}\right)^{T}}
$$

Model-specific assumptions:

This is a special case of the residual income valuation model. It uses actual book values per share and forecasted earnings per share up to three years ahead to impute future expected residual income for an initial three-year period. We assume clean surplus, i.e., future book values are imputed from current book values, forecasted earnings and dividends. Dividends are set equal to a constant fraction of forecasted earnings. After the explicit forecast period of three years, the residual income series is derived by linearly fading the forecasted accounting return on equity to the industry-specific median return. We compute the historic three-year average return on equity in a given country and year based on the industry classification in Campbell [1996]. Negative yearly target returns are replaced by countryindustry medians. From $T=12$ on residual income is assumed to remain constant.

Ohlson and Juettner-Nauroth [2005]:

$$
P_{t}=\left(\hat{x}_{t+1} / r_{O J}\right) \cdot\left(g_{s t}+r_{O J} \cdot \hat{d}_{t+1} / \hat{x}_{t+1}-g_{l t}\right) /\left(r_{O J}-g_{l t}\right)
$$

Model-specific assumptions:

This is a special case of the abnormal earnings growth valuation model developed by Ohlson and Juettner-Nauroth [2005]. It uses one-year ahead forecasted earnings and dividends per share as well as forecasts of short-term and long-term abnormal earnings growth. Dividends are set equal to a constant fraction of forecasted earnings. Following Gode and Mohanram [2003], the short-term growth rate $g_{s t}$ is estimated as the average between the forecasted percentage change in earnings from year $t+1$ to $t+2$ and the five-year growth forecast provided by financial analysts on $\mathrm{I} / \mathrm{B} / \mathrm{E} / \mathrm{S}$. The model requires a positive change in forecasted earnings to yield a numerical solution. The long-term earnings growth rate $g_{l t}$ incorporates the assumption that growth in abnormal earnings per share beyond year $t+1$ equals the expected rate of inflation. We use the (annualized) country-specific median of oneyear-ahead realized monthly inflation rates. Note that $g_{l t}$ sets a lower bound to the cost of capital estimates.

Modified PEG ratio model by Easton [2004]:

$$
P_{t}=\left(\hat{x}_{t+2}+r_{P E G} \cdot \hat{d}_{t+1}-\hat{x}_{t+1}\right) / r_{P E G}^{2}
$$

Model-specific assumptions:

This is a special case of the abnormal earnings growth valuation model developed by Ohlson and Juettner-Nauroth [2005]. It uses one-year ahead and two-year ahead earnings per share forecasts as well as expected dividends per share in period $t+1$ to derive a measure of abnormal earnings growth. Dividends are set equal to a constant fraction of forecasted earnings. The model embeds the assumption that growth in abnormal earnings persists in perpetuity after the initial period. Note that it requires positive changes in forecasted earnings (including re-invested dividends) to yield a numerical solution. 


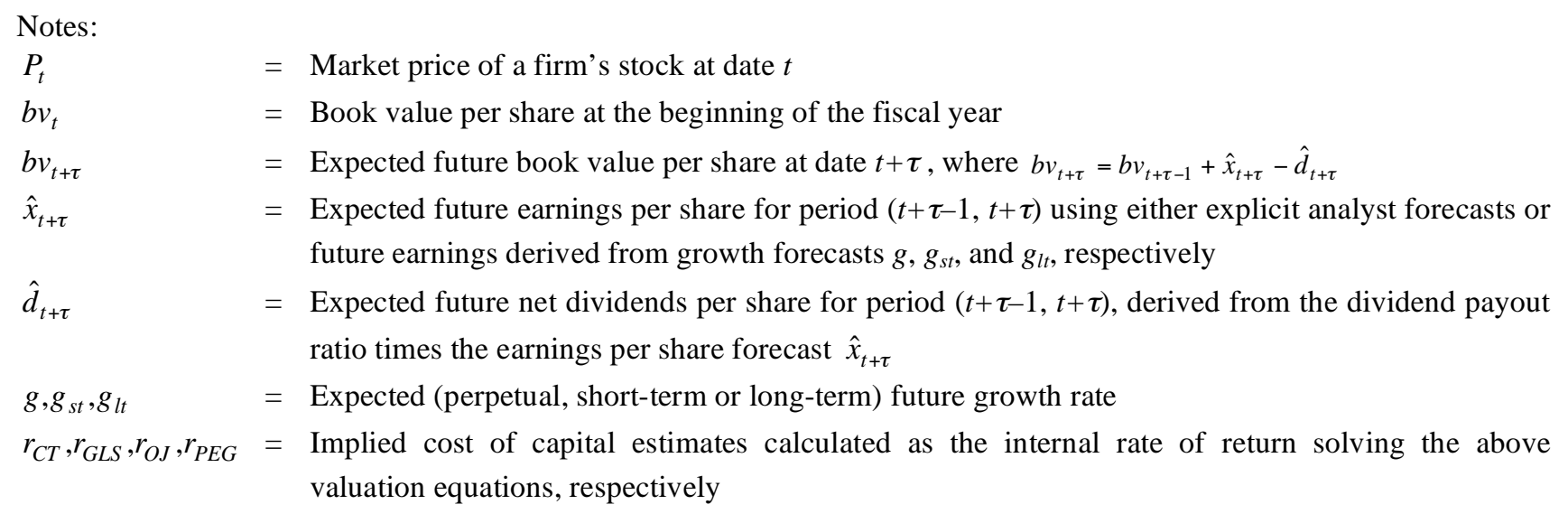

The computation of the implied cost of capital estimates is based on several data sources and requires a series of general assumptions. For an observation to be included in the cost of capital sample we require current stock price data $\left(P_{t}\right)$, analyst earnings per share forecasts for two periods ahead $\left(\hat{x}_{t+1}\right.$ and $\left.\hat{x}_{t+2}\right)$, and either forecasted earnings per share for period $t+3\left(\hat{x}_{t+3}\right)$ or an estimate of long-term earnings growth (ltg). We obtain this information from the $\mathrm{I} / \mathrm{B} / \mathrm{E} / \mathrm{S}$ database. If explicit earnings per share forecasts for the periods $t+3$ through $t+5$ are missing, we apply the following relation: $\hat{x}_{t+\tau}=\hat{x}_{t+\tau-1} \cdot(1+\operatorname{ltg})$. Alternatively, if long-term growth projections are missing, we impute ltg from the percentage change in forecasted earnings per share between periods $t+2$ and $t+3$. We only use positive earnings forecasts and growth rates in our computations. All estimates are mean analyst consensus forecasts.

Stock prices and analyst forecasts are measured as of month +7 after the fiscal year end. This time lag is chosen to ensure that financial data, especially earnings and book values of equity, are publicly available and impounded in firms' prices at the time we compute the cost of capital. Given this choice, analyst forecasts represent estimates for fiscal years ending in just 5, 17, 29, etc. months. The valuation models, on the other hand, assume discounting for a full year, i.e., they start at the beginning of the fiscal year. For consistent discounting, we first move the month +7 prices (which contain the information available at the time of forecasting) back to the beginning of the fiscal year 
using the imputed cost of capital and then use full-year discounting. This procedure merely shifts prices over time for proper discounting and is equivalent to applying partial-year discount factors.

Net dividends $\left(\hat{d}_{t+\tau}\right)$ are forecasted up to the finite forecast horizon as a constant fraction of expected future earnings per share. We define the dividend payout ratio $\left(k_{t}\right)$ as the historic three-year average for each firm. If $k_{t}$ is missing or outside the range of zero and one, we replace it by the country-year median payout ratio. We use the (annualized) country-specific median of one-yearahead realized monthly inflation rates as our proxy for long-run growth expectations $\left(g\right.$ or $\left.g_{l t}\right)$ in the terminal value computations. Negative values are replaced by the country's historical inflation rate, estimated as the median of the monthly inflation rates over the 1980 to 2005 period, because deflation cannot persist forever. We obtain all financial data $\left(b v_{t}\right.$ and $\left.k_{t}\right)$ from Worldscope. Inflation data are gathered from the Datastream and World Bank databases.

Since most of the valuation models do not have a closed form solution, we use an iterative procedure to determine the internal rate of return. This numerical approximation identifies the annual firm-specific discount rate that equates $P_{t}$ to the right-hand side of the respective equity valuation model. We stop iterating if the imputed price falls within a 0.001 difference of its actual value. Implied cost of equity capital estimates are restricted to be positive and set to missing otherwise.

\section{A.6. TOBIN'S Q}

The final dependent variable is Tobin's q. It is a metric that is frequently used in the corporate finance literature (e.g., Servaes [1991], Lang and Stulz [1994]) as well as in international studies (La Porta et al. [2002], Doidge, Karolyi, and Stulz [2004], Lang, Lins, and Miller [2004]). Higher values of Tobin's q could reflect differences in expected discount rates and/or differences in expected future cash flows (or growth expectations). It is therefore a more comprehensive measure than the cost of capital. If, for instance, better transparency increases growth expectations (e.g., because better 
transparency improves outsiders' ability to monitor controlling insiders), Tobin's q can capture the resulting changes in future expected cash flows, even when the cost of capital stays constant. Tobin's $\mathrm{q}$ also captures costs associated with the implementation of IFRS (e.g., auditing fees). Furthermore, a decrease in the cost of capital should, ceteris paribus, result in an increase in Tobin's q.

We compute Tobin's q as (total assets - book value of equity + market value of equity) scaled by total assets. It is essentially a market-to-book ratio for the entity. For consistency with the other proxies, we measure the market value as of month +7 after the fiscal year end. We obtain financial data from Worldscope and gather prices and the numbers of shares outstanding from Datastream. We note that the measurement of total assets (and hence Tobin's q) is affected by differences in accounting standards across countries. However, to the extent that they result in systematic biases that are stable over time, the industry-year and firm-fixed effects in our regressions should subsume these differences. In addition, the switch to IFRS likely affects the denominator of Tobin's q even when there is no capital-market effect. This introduces bias into the measurement of the q metric depending on the direction of the revaluation effect (e.g., Hung and Subramanyam [2007]). 


\section{REFERENCES}

AMIHUD, Y. “Illiquidity and Stock Returns.” Journal of Financial Markets 5 (2002): 31-56.

Armstrong, C.; M. BARTh; A. Jagolinzer; AND E. RIEDL. "Market Reaction to Events Surrounding the Adoption of IFRS in Europe." Working paper, Harvard Business School and Stanford University, 2007. Available at SSRN: http://ssrn.com/abstract=903429.

BAE, K.-H.; H. TAN; AND M. WELKER. "International GAAP Differences: The Impact on Foreign Analysts." The Accounting Review 83 (2008): 593-628.

BALL, R. "IFRS: Pros and Cons for Investors." Accounting \& Business Research International Accounting Policy Forum (2006): 5-27.

BALl, R.; S. P. Kothari; AND A. Robin. "The Effect of International Institutional Factors of Properties of Accounting Earnings." Journal of Accounting \& Economics 29 (2000): 1-51.

BALl, R.; A. Robin; AND J. WU. "Incentives Versus Standards: Properties of Accounting Income in Four East Asian Countries.” Journal of Accounting \& Economics 36 (2003): 235-70.

Ball, R., And L. Shivakumar. "Earnings Quality in U.K. Private Firms." Journal of Accounting \& Economics 39 (2005): 83-128.

BARTH, M.; W. LANDSMAN; AND M. LANG. "International Accounting Standards and Accounting Quality." Journal of Accounting Research 46 (2008): 467-98.

Bekaert, G.; C. Harvey; And C. Lundblad. "Liquidity and Expected Returns: Lessons from Emerging Markets.” Review of Financial Studies 20 (2007): 1783-1831.

Botosan, C. "Disclosure Level and the Cost of Equity Capital." The Accounting Review 72 (1997): 323-49.

Botosan, C., And M. Plumlee. "A Re-examination of Disclosure Level and the Expected Cost of Equity Capital.” Journal of Accounting Research 40 (2002): 21-40.

Bradshaw, M.; B. Bushee; And G. Miller. "Accounting Choice, Home Bias, and U.S. Investment in Non-U.S. Firms.” Journal of Accounting Research 42 (2004): 795-841.

Burgstahler, D.; L. HaIL; AND C. LeuZ. "The Importance of Reporting Incentives: Earnings Management in European Private and Public Firms." The Accounting Review 81 (2006): 9831017.

CAmpbell, J. “Understanding Risk and Return.” Journal of Political Economy 104 (1996): 298-345.

Capkun, V.; A. Cazavan-Jeny; T. Jeanjean; and L. Weiss. "Earnings Management and Value Relevance during the Mandatory Transition from Local GAAPs to IFRS in Europe." Working paper, Georgetown University, 2008. Available at SSRN: http://ssrn.com/abstract=1125716.

Chordia, T.; R. Roll; And A. Subrahmanyam. "Co-Movements in Bid-Ask Spreads and Market Depth." Financial Analysts Journal 56 (2000): 23-7.

Christensen, H.; E. LeE; AND M. WALKer. "Cross-Sectional Variation in the Economic Consequences of International Accounting Harmonisation: The Case of Mandatory IFRS Adoption in the UK." International Journal of Accounting 42 (2007a), 341-79.

Christensen, H.; E. LeE; AND M. WALKER. "Do IFRS/UK-GAAP Reconciliations Convey New Information?" Working paper, Manchester Business School, 2007b. Available at SSRN: http://ssrn.com/abstract=997800. 
Claus, J., And J. Thomas. "Equity Premia as Low as Three Percent? Evidence from Analysts' Earnings Forecasts for Domestic and International Stock Markets." Journal of Finance 56 (2001): 1629-66.

COFFEE, J. "Market Failure and the Economic Case for a Mandatory Disclosure System." Virginia Law Review 70 (1984): 717-53.

COMPriX, J.; K. Muller; AND M. STANDFORD-HARris. "Economic Consequences from Mandatory Adoption of IASB Standards in the European Union." Working paper, Penn State University, 2003.

Covrig, V.; M. DeFond; And M. Hung. "Home Bias, Foreign Mutual Fund Holdings, and the Voluntary Adoption of International Accounting Standards." Journal of Accounting Research 45 (2007): 41-70.

Daske, H., And G. GebhardT. "International Financial Reporting Standards and Experts' Perceptions of Disclosure Quality." Abacus 42 (2006): 461-98.

Daske, H.; L. HaIL; C. LeuZ; AND R. VerdI. "Adopting a Label: Heterogeneity in the Economic Consequences of IFRS Adoptions." Working paper, University of Pennsylvania and University of Chicago, 2007. Available at SSRN: http://ssrn.com/abstract=979650.

Demaria, S., AND D. Dufour. "First Time Adoption of IFRS, Fair Value Option, Conservatism: Evidence from French Listed Companies.” Working paper, Nice Sophia Antipolis University, 2007.

Ding, Y.; O.-K. Hope; T. Jeanjean; And H. Stolowy. "Differences between Domestic Accounting Standards and IAS: Measurement, Determinants and Implications." Journal of Accounting \& Public Policy 26 (2007): 1-38.

Doidge, C.; G. A. Karolyi; And R. Stulz. "Why Are Foreign Firms Listed in the U.S. Worth More?" Journal of Financial Economics 71 (2004): 205-38.

DYE, R. "Mandatory Versus Voluntary Disclosures: The Cases of Financial and Real Externalities." The Accounting Review 65 (1990): 1-24.

EAston, P. "PE Ratios, PEG Ratios, and Estimating the Implied Expected Rate of Return on Equity Capital." The Accounting Review 79 (2004): 79-95.

ENRIQUes L., AND P. VolPIN. "Corporate Governance Reforms in Continental Europe.” Journal of Economic Perspectives 21 (2007): 117-40.

ERNST \& YOUNG. IFRS: Observations on the Implementation of IFRS. London: EYGM Limited, 2007.

Ewert, R., AND A. Wagenhofer. "Economic Effects of Tightening Accounting Standards to Restrict Earnings Management." The Accounting Review 80 (2005): 1101-24.

Francis, J.; R. LAFond; P. Olsson; And K. SchipPer. "Cost of Capital and Earnings Attributes." The Accounting Review 79 (2004): 967-1010.

Gebhardt, W.; C. Lee; And B. Swaminathan. "Toward an Implied Cost of Capital." Journal of Accounting Research 39 (2001): 135-76.

Glosten, L., And P. Milgrom. "Bid, Ask and Transaction Prices in a Specialist Market with Heterogeneously Informed Traders.” Journal of Financial Economics 14 (1985): 71-100.

Gode, D., AND P. Mohanram. "Inferring the Cost of Capital Using the Ohlson-Juettner Model." Review of Accounting Studies 8 (2003): 399-431. 
Gordon, E.; B. JoRgensen; AND C. LinTHICUM. "Could IFRS Replace US GAAP? A Comparison of Earnings Attributes and Informativeness in the US Market." Working paper, Temple University, Columbia University and University of Texas at San Antonio, 2008. Available at SSRN: http://ssrn.com/abstract=1132908.

Goyenko, R.; C. Holden; C. Lundblad; And C. Trzcinka. "Horseraces of Monthly and Annual Liquidity Measures." Working paper, Indiana University, 2006. Available at SSRN: http://ssrn.com/abstract=672702.

HaIL, L. "The Impact of Voluntary Corporate Disclosures on the Ex-Ante Cost of Capital for Swiss Firms." European Accounting Review 11 (2002): 741-73.

HaIL, L., AND C. LeUZ. "International Differences in the Cost of Equity Capital: Do Legal Institutions and Securities Regulation Matter?" Journal of Accounting Research 44 (2006): 485531.

HaIL, L., AND C. LEUZ. Capital Market Effects of Mandatory IFRS Reporting in the EU: Empirical Evidence. Amsterdam: Netherlands Authority for the Financial Markets, 2007. Available at: http://www.afm.nl/corporate/default.ashx?DocumentId=10519.

HAIL, L., AND C. LEUZ. "Cost of Capital Effects and Changes in Growth Expectations around U.S. Cross-Listings." Working paper, University of Pennsylvania and University of Chicago, 2008. Available at SSRN: http://ssrn.com/abstract=938230.

Healy, P.; A. Hutton; AND K. PalePu. "Stock Performance and Intermediation Changes Surrounding Sustained Increases in Disclosure." Contemporary Accounting Research 16 (1999): 485-520.

Hope, O.-K. "Disclosure Practices, Enforcement of Accounting Standards, and Analysts' Forecast Accuracy: An International Study." Journal of Accounting Research 41 (2003): 235-72.

Hughes, S., AND J. SANDER. "Are IFRS and US GAAP Converging? Preliminary Evidence from Three European Union Countries." Working paper, University of Vermont, 2007.

Hung, M., And K. Subramanyam. "Financial Statement Effects of Adopting International Accounting Standards: The Case of Germany." Review of Accounting Studies 12 (2007): 623-57.

ICAEW. EU Implementation of IFRS and the Fair Value Directive: A Report for the European Commission. London: Institute of Chartered Accountants in England and Wales, 2007.

Kaufmann, D.; A. KraAy; And M. MastruZZI. "Governance Matters VI: Aggregate and Individual Governance Indicators 1996-2006." The World Bank, 2007.

KPMG. The Application of IFRS: Choices in Practice. London: KPMG IFRG Limited, 2006.

KYLE, A. "Continuous Auctions and Insider Trading.” Econometrica 53 (1985): 1315-35.

La Porta, R.; F. Lopez-De-Silanes; A. Shleifer; And R. Vishny. "Law and Finance." Journal of Political Economy 106 (1998): 1113-55.

La Porta, R.; F. Lopez-De-Silanes; A. Shleifer; And R. Vishny. "Investor Protection and Corporate Valuation." Journal of Finance 57 (2002): 1147-70.

LAMBERT, R.; C. LeuZ; AND R. VERRECCHIA. "Accounting Information, Disclosure, and the Cost of Capital." Journal of Accounting Research 45 (2007): 385-420.

LANG, M.; K. Lins; AND D. Miller. "Concentrated Control, Analyst Following, and Valuation: Do Analysts Matter Most When Investors Are Protected Least?” Journal of Accounting Research 42 (2004): 589-623. 
Lang, M.; J. Smith Raedy; And W. Wilson. "Earnings Management and Cross Listing: Are Reconciled Earnings Comparable to US Earnings?" Journal of Accounting \& Economics 42 (2006): 255-83.

LANG, L., AND R. STUlz. “Tobin's q, Corporate Diversification, and Firm Performance.” Journal of Political Economy 102 (1994): 1248-80.

LESMOND, D. "The Costs of Equity Trading in Emerging Markets." Journal of Financial Economics 77 (2005): 411-52.

Lesmond, D.; J. Ogden; And C. TrZcinka. "A New Estimate of Transaction Costs." Review of Financial Studies 12 (1999): 1113-41.

LEUZ, C. "IAS versus US GAAP: Information Asymmetry-Based Evidence from Germany's New Market." Journal of Accounting Research 41 (2003): 445-72.

LEuZ, C. "Cross Listing, Bonding and Firms' Reporting Incentives: A Discussion of Lang, Raedy and Wilson." Journal of Accounting \& Economics 42 (2006): 285-99.

LeuZ, C.; D. NANDA; AND P. WysocKI. "Earnings Management and Investor Protection: An International Comparison.” Journal of Financial Economics 69 (2003): 505-27.

LEUZ, C., AND R. VERRECCHIA. "The Economic Consequences of Increased Disclosure." Journal of Accounting Research 38 (2000), 91-124.

Merton, R. “A Simple Model of Capital Market Equilibrium with Incomplete Information.” Journal of Finance 42 (1987): 483-510.

Ohlson, J., AND B. JuetTner-NAuroth. "Expected EPS and EPS Growth as Determinants of Value." Review of Accounting Studies 10 (2005): 349-65.

Platikanova, P. "Market Liquidity Effects of the IFRS Introduction in Europe." Working paper, University Pompeu Fabra, 2007. Available at SSRN: http://ssrn.com/abstract=1005364.

PWC/IPSOs MORI. Has the Dust Settled Yet? London: PricewaterhouseCoopers LLP, 2007.

Quick, R.; S. TuRleY; AND M. Willekens. Auditing, Trust and Governance: Developing Regulation in Europe. London and New York: Routledge, 2008.

SERVAES, H. “Tobin's Q and Gains from Takeovers.” Journal of Finance 46 (1991): 409-19.

StOLl, H. "The Supply of Dealer Services in Securities Markets." Journal of Finance 33 (1978): $1133-51$.

VerrecchiA, R. “Essays on Disclosure.” Journal of Accounting \& Economics 32 (2001): 91-180.

Watts, R., And J. Zimmermann. Positive Accounting Theory. Edgewood Cliffs: Prentice Hall, 1986.

Welker, M. "Disclosure Policy, Information Asymmetry, and Liquidity in Equity Markets." Contemporary Accounting Research 11 (1995): 801-27. 
TABLE 1

Sample Composition by Country and Year

Panel A: Accounting Standards, Listing Status and Index Membership by IFRS Adoption Country (Treatment Sample)

\begin{tabular}{|c|c|c|c|c|c|c|c|c|c|c|c|c|c|c|c|c|}
\hline \multirow[b]{3}{*}{$\begin{array}{l}\text { IFRS Adoption } \\
\text { Countries }\end{array}$} & \multirow[b]{3}{*}{$\begin{array}{l}\text { Unique } \\
\text { Firms }\end{array}$} & \multirow[b]{3}{*}{$\begin{array}{l}\text { Firm- } \\
\text { Years }\end{array}$} & \multicolumn{6}{|c|}{ IFRS } & \multirow{2}{*}{\multicolumn{2}{|c|}{ U.S. GAAP }} & \multirow{2}{*}{\multicolumn{2}{|c|}{ U.S. Listing }} & \multirow{2}{*}{\multicolumn{2}{|c|}{ New Markets }} & \multirow{2}{*}{\multicolumn{2}{|c|}{ Index Member }} \\
\hline & & & \multicolumn{2}{|c|}{$\begin{array}{c}\text { Early } \\
\text { Voluntary }\end{array}$} & \multicolumn{2}{|c|}{$\begin{array}{c}\text { Late } \\
\text { Voluntary }\end{array}$} & \multicolumn{2}{|c|}{$\begin{array}{l}\text { First-Time } \\
\text { Mandatory }\end{array}$} & & & & & & & & \\
\hline & & & $\begin{array}{l}\text { Firm- } \\
\text { Years }\end{array}$ & $\%$ & $\begin{array}{l}\text { Firm- } \\
\text { Years }\end{array}$ & $\%$ & $\begin{array}{l}\text { Firm- } \\
\text { Years }\end{array}$ & $\%$ & $\begin{array}{l}\text { Firm- } \\
\text { Years }\end{array}$ & $\%$ & $\begin{array}{l}\text { Firm- } \\
\text { Years }\end{array}$ & $\%$ & $\begin{array}{l}\text { Firm- } \\
\text { Years }\end{array}$ & $\%$ & $\begin{array}{l}\text { Firm- } \\
\text { Years }\end{array}$ & $\%$ \\
\hline Australia & 1,159 & 4,585 & 42 & 0.9 & 2 & 0.0 & 110 & 2.4 & 3 & 0.1 & 237 & 5.2 & 23 & 0.5 & 1,650 & 36.0 \\
\hline Austria & 106 & 386 & 182 & 47.2 & 32 & 8.3 & 17 & 4.4 & 22 & 5.7 & 66 & 17.1 & 47 & 12.2 & 111 & 28.8 \\
\hline Belgium & 139 & 552 & 52 & 9.4 & 27 & 4.9 & 56 & 10.1 & 4 & 0.7 & 18 & 3.3 & 0 & 0.0 & 135 & 24.5 \\
\hline Czech Republic & 20 & 57 & 23 & 40.4 & 0 & 0.0 & 5 & 8.8 & 0 & 0.0 & 5 & 8.8 & 0 & 0.0 & 13 & 22.8 \\
\hline Denmark & 182 & 732 & 58 & 7.9 & 23 & 3.1 & 62 & 8.5 & 0 & 0.0 & 16 & 2.2 & 0 & 0.0 & 129 & 17.6 \\
\hline Finland & 135 & 607 & 13 & 2.1 & 9 & 1.5 & 99 & 16.3 & 0 & 0.0 & 25 & 4.1 & 0 & 0.0 & 151 & 24.9 \\
\hline France & 812 & 3,211 & 94 & 2.9 & 20 & 0.6 & 370 & 11.5 & 9 & 0.3 & 141 & 4.4 & 0 & 0.0 & 1,377 & 42.9 \\
\hline Germany & 779 & 2,994 & 805 & 26.9 & 275 & 9.2 & 216 & 7.2 & 406 & 13.6 & 115 & 3.8 & 1,049 & 35.0 & 556 & 18.6 \\
\hline Greece & 303 & 1,236 & 12 & 1.0 & 9 & 0.7 & 150 & 12.1 & 4 & 0.3 & 24 & 1.9 & 0 & 0.0 & 324 & 26.2 \\
\hline Hong Kong & 739 & 3,135 & 51 & 1.6 & 1 & 0.0 & 346 & 11.0 & 15 & 0.5 & 341 & 10.9 & 46 & 1.5 & 639 & 20.4 \\
\hline Hungary & 37 & 145 & 79 & 54.5 & 2 & 1.4 & 3 & 2.1 & 4 & 2.8 & 20 & 13.8 & 0 & 0.0 & 10 & 6.9 \\
\hline Ireland & 72 & 288 & 0 & 0.0 & 0 & 0.0 & 36 & 12.5 & 6 & 2.1 & 58 & 20.1 & 10 & 3.5 & 229 & 79.5 \\
\hline Italy & 265 & 1,142 & 296 & 25.9 & 46 & 4.0 & 79 & 6.9 & 2 & 0.2 & 30 & 2.6 & 33 & 2.9 & 260 & 22.8 \\
\hline Luxembourg & 30 & 123 & 33 & 26.8 & 0 & 0.0 & 13 & 10.6 & 9 & 7.3 & 11 & 8.9 & 5 & 4.1 & 57 & 46.3 \\
\hline The Netherlands & 213 & 898 & 45 & 5.0 & 5 & 0.6 & 129 & 14.4 & 57 & 6.3 & 115 & 12.8 & 47 & 5.2 & 177 & 19.7 \\
\hline Norway & 169 & 631 & 10 & 1.6 & 1 & 0.2 & 93 & 14.7 & 6 & 1.0 & 46 & 7.3 & 0 & 0.0 & 147 & 23.3 \\
\hline Philippines & 156 & 605 & 0 & 0.0 & 4 & 0.7 & 113 & 18.7 & 0 & 0.0 & 26 & 4.3 & 5 & 0.8 & 147 & 24.3 \\
\hline Poland & 100 & 383 & 25 & 6.5 & 4 & 1.0 & 55 & 14.4 & 2 & 0.5 & 19 & 5.0 & 0 & 0.0 & 73 & 19.1 \\
\hline Portugal & 60 & 242 & 6 & 2.5 & 7 & 2.9 & 37 & 15.3 & 0 & 0.0 & 14 & 5.8 & 0 & 0.0 & 143 & 59.1 \\
\hline Singapore & 423 & 1,878 & 31 & 1.7 & 26 & 1.4 & 960 & 51.1 & 15 & 0.8 & 97 & 5.2 & 1,756 & 93.5 & 427 & 22.7 \\
\hline South Africa & 394 & 1,389 & 70 & 5.0 & 6 & 0.4 & 38 & 2.7 & 3 & 0.2 & 164 & 11.8 & 0 & 0.0 & 421 & 30.3 \\
\hline Spain & 141 & 574 & 4 & 0.7 & 0 & 0.0 & 91 & 15.9 & 2 & 0.3 & 34 & 5.9 & 38 & 6.6 & 261 & 45.5 \\
\hline Sweden & 302 & 1,211 & 11 & 0.9 & 4 & 0.3 & 168 & 13.9 & 0 & 0.0 & 55 & 4.5 & 48 & 4.0 & 145 & 12.0 \\
\hline Switzerland & 255 & 1,060 & 541 & 51.0 & 24 & 2.3 & 69 & 6.5 & 34 & 3.2 & 45 & 4.2 & 9 & 0.8 & 183 & 17.3 \\
\hline United Kingdom & 1,715 & 6,529 & 9 & 0.1 & 2 & 0.0 & 418 & 6.4 & 16 & 0.2 & 413 & 6.3 & 5 & 0.1 & 2,750 & 42.1 \\
\hline Venezuela & 20 & 80 & 0 & 0.0 & 0 & 0.0 & 8 & 10.0 & 4 & 5.0 & 37 & 46.3 & 0 & 0.0 & 57 & 71.3 \\
\hline Total & 8,726 & 34,673 & 2,492 & 7.2 & 529 & 1.5 & 3,741 & 10.8 & 623 & 1.8 & 2,172 & 6.3 & 3,121 & 9.0 & 10,572 & 30.5 \\
\hline
\end{tabular}


TABLE 1 - Continued

Panel B: Accounting Standards, Listing Status and Index Membership by Non-IFRS Adoption Country (Benchmark Sample)

\begin{tabular}{|c|c|c|c|c|c|c|c|c|c|c|c|}
\hline \multirow{2}{*}{$\begin{array}{l}\text { Non-IFRS } \\
\text { Adoption } \\
\text { Countries }\end{array}$} & \multirow[b]{2}{*}{$\begin{array}{c}\text { Unique } \\
\text { Firms }\end{array}$} & \multirow[b]{2}{*}{$\begin{array}{l}\text { Firm- } \\
\text { Years }\end{array}$} & \multirow{2}{*}{$\begin{array}{c}\text { Randomly } \\
\text { Selected } \\
\text { Firm-Years }\end{array}$} & \multicolumn{2}{|c|}{ U.S. GAAP } & \multicolumn{2}{|c|}{ U.S. Listing } & \multicolumn{2}{|c|}{ New Markets } & \multicolumn{2}{|c|}{ Index Member } \\
\hline & & & & $\begin{array}{l}\text { Firm- } \\
\text { Years }\end{array}$ & $\%$ & $\begin{array}{l}\text { Firm- } \\
\text { Years }\end{array}$ & $\%$ & $\begin{array}{l}\text { Firm- } \\
\text { Years }\end{array}$ & $\%$ & $\begin{array}{l}\text { Firm- } \\
\text { Years }\end{array}$ & $\%$ \\
\hline Argentina & 66 & 252 & 252 & 2 & 0.8 & 64 & 25.4 & 0 & 0.0 & 64 & 25.4 \\
\hline Bermuda & 18 & 74 & 74 & 34 & 45.9 & 5 & 6.8 & 0 & 0.0 & 0 & 0.0 \\
\hline Brazil & 202 & 766 & 452 & 0 & 0.0 & 199 & 26.0 & 69 & 9.0 & 208 & 27.2 \\
\hline Canada & 1,219 & 4,712 & 509 & 115 & 2.4 & 729 & 15.5 & 3 & 0.1 & 1,252 & 26.6 \\
\hline Chile & 133 & 536 & 536 & 0 & 0.0 & 81 & 15.1 & 0 & 0.0 & 134 & 25.0 \\
\hline China & 997 & 3,232 & 425 & 29 & 0.9 & 17 & 0.5 & 0 & 0.0 & 15 & 0.5 \\
\hline Colombia & 26 & 96 & 96 & 0 & 0.0 & 5 & 5.2 & 0 & 0.0 & 48 & 50.0 \\
\hline Egypt & 16 & 57 & 57 & 0 & 0.0 & 7 & 12.3 & 0 & 0.0 & 21 & 36.8 \\
\hline India & 397 & 1,514 & 516 & 6 & 0.4 & 41 & 2.7 & 0 & 0.0 & 175 & 11.6 \\
\hline Indonesia & 254 & 1,047 & 595 & 0 & 0.0 & 18 & 1.7 & 5 & 0.5 & 1,017 & 97.1 \\
\hline Israel & 143 & 503 & 461 & 168 & 33.4 & 38 & 7.6 & 27 & 5.4 & 135 & 26.8 \\
\hline Japan & 3,464 & 15,950 & 683 & 55 & 0.3 & 207 & 1.3 & 103 & 0.6 & 7,779 & 48.8 \\
\hline Korea (South) & 748 & 2,969 & 519 & 0 & 0.0 & 37 & 1.2 & 0 & 0.0 & 2,594 & 87.4 \\
\hline Malaysia & 763 & 3,417 & 667 & 0 & 0.0 & 40 & 1.2 & 0 & 0.0 & 724 & 21.2 \\
\hline Mexico & 97 & 385 & 385 & 2 & 0.5 & 173 & 44.9 & 0 & 0.0 & 137 & 35.6 \\
\hline Morocco & 22 & 81 & 81 & 0 & 0.0 & 0 & 0.0 & 0 & 0.0 & 17 & 21.0 \\
\hline New Zealand & 105 & 434 & 434 & 0 & 0.0 & 13 & 3.0 & 3 & 0.7 & 121 & 27.9 \\
\hline Pakistan & 71 & 305 & 305 & 0 & 0.0 & 0 & 0.0 & 0 & 0.0 & 213 & 69.8 \\
\hline Peru & 27 & 102 & 102 & 0 & 0.0 & 13 & 12.7 & 0 & 0.0 & 25 & 24.5 \\
\hline Russia & 24 & 79 & 79 & 11 & 13.9 & 45 & 57.0 & 0 & 0.0 & 0 & 0.0 \\
\hline Sri Lanka & 25 & 80 & 80 & 0 & 0.0 & 0 & 0.0 & 0 & 0.0 & 0 & 0.0 \\
\hline Taiwan & 722 & 3,019 & 562 & 8 & 0.3 & 25 & 0.8 & 0 & 0.0 & 2,304 & 76.3 \\
\hline Thailand & 325 & 1,369 & 584 & 0 & 0.0 & 49 & 3.6 & 5 & 0.4 & 1,302 & 95.1 \\
\hline Turkey & 112 & 447 & 309 & 0 & 0.0 & 8 & 1.8 & 0 & 0.0 & 194 & 43.4 \\
\hline United States & 7,413 & 29,428 & 563 & 0 & 0.0 & 0 & 0.0 & 26 & 0.1 & 8,142 & 27.7 \\
\hline Total & 17,389 & 70,854 & 9,326 & 430 & 0.6 & 1,814 & 2.6 & 241 & 0.3 & 26,621 & 37.6 \\
\hline
\end{tabular}


TABLE 1 - Continued

Panel C: Accounting Standards, Listing Status and Index Membership by Year (Complete Sample)

\begin{tabular}{|c|c|c|c|c|c|c|c|c|c|c|c|c|c|c|c|}
\hline \multirow[b]{3}{*}{ Year } & \multirow[b]{3}{*}{ Firms } & \multicolumn{6}{|c|}{ IFRS } & & & & & & & & \\
\hline & & \multicolumn{2}{|c|}{$\begin{array}{c}\text { Early } \\
\text { Voluntary }\end{array}$} & \multicolumn{2}{|c|}{$\begin{array}{c}\text { Late } \\
\text { Voluntary }\end{array}$} & \multicolumn{2}{|c|}{$\begin{array}{l}\text { First-Time } \\
\text { Mandatory }\end{array}$} & \multicolumn{2}{|c|}{ U.S. GAAP } & \multicolumn{2}{|c|}{ U.S. Listing } & \multicolumn{2}{|c|}{ New Markets } & \multicolumn{2}{|c|}{ Index Member } \\
\hline & & $\begin{array}{l}\text { Firm- } \\
\text { Years }\end{array}$ & $\%$ & $\begin{array}{l}\text { Firm- } \\
\text { Years }\end{array}$ & $\%$ & $\begin{array}{l}\text { Firm- } \\
\text { Years }\end{array}$ & $\%$ & $\begin{array}{l}\text { Firm- } \\
\text { Years }\end{array}$ & $\%$ & $\begin{array}{l}\text { Firm- } \\
\text { Years }\end{array}$ & $\%$ & $\begin{array}{l}\text { Firm- } \\
\text { Years }\end{array}$ & $\%$ & $\begin{array}{l}\text { Firm- } \\
\text { Years }\end{array}$ & $\%$ \\
\hline 2001 & 21,050 & 561 & 2.7 & 2 & 0.0 & 0 & 0.0 & 228 & 1.1 & 814 & 3.9 & 615 & 2.9 & 7,261 & 34.5 \\
\hline 2002 & 21,823 & 532 & 2.4 & 67 & 0.3 & 0 & 0.0 & 239 & 1.1 & 832 & 3.8 & 697 & 3.2 & 7,651 & 35.1 \\
\hline 2003 & 21,841 & 476 & 2.2 & 102 & 0.5 & 225 & 1.0 & 237 & 1.1 & 829 & 3.8 & 690 & 3.2 & 7,656 & 35.1 \\
\hline 2004 & 21,087 & 456 & 2.2 & 185 & 0.9 & 368 & 1.7 & 215 & 1.0 & 783 & 3.7 & 685 & 3.2 & 7,488 & 35.5 \\
\hline 2005 & 19,726 & 467 & 2.4 & 173 & 0.9 & 3,148 & 16.0 & 134 & 0.7 & 728 & 3.7 & 675 & 3.4 & 7,137 & 36.2 \\
\hline Total & 105,527 & 2,492 & 2.4 & 529 & 0.5 & 3,741 & 3.5 & 1,053 & 1.0 & 3,986 & 3.8 & 3,362 & 3.2 & 37,193 & 35.2 \\
\hline
\end{tabular}

The full sample comprises a maximum of 105,527 firm-year observations from 51 countries between 2001 and 2005 with sufficient financial data from Worldscope and price/volume data from Datastream to estimate our least restrictive specification (i.e., Model 3 for Zero Returns in Table 4, Panel B using the worldwide sample as benchmark). For simplicity, we refer to Hong Kong as a country in our analyses, although, more appropriately, it has the status of a Special Administrative Region (SAR) of the People's Republic of China. The sample includes only countries with at least 20 firm-year observations. We split the sample countries into two groups: (1) countries that mandated the adoption of IFRS reporting (treatment sample), and (2) countries that do not allow or do not require IFRS reporting during our sample period (benchmark sample). Panel A includes local GAAP and IFRS firm-year observations for IFRS countries. Panels A and B report the number of firms, the number and percentage of firm-year observations for IFRS and non-IFRS adoption countries, respectively. Panel B also indicates the number of firm-years in a benchmark sample comprising a maximum of 150 randomly selected companies per country. Panel C reports the number of observations and corresponding percentages for the complete sample by year. We report descriptive information for the following indicator variables (coded one if the definition applies to a given firm-year observation and zero otherwise): IFRS and U.S. GAAP indicate financial reports following the two sets of accounting standards, respectively, based on the "accounting standards followed" field in Worldscope (Field 07536) and adjusted for contradicting coding from an extensive manual review of firms' annual reports (see Appendix A in Daske et al. [2007] for details). Note that U.S. GAAP only applies to non-U.S. firms (i.e., equals zero for U.S. firms) as we also introduce country dummies. We split treatment sample firms that apply IFRS before it was mandated by local regulation into two distinctive groups: (1) Early Voluntary marks the subset of firms voluntarily switching to IFRS prior to the announcement by local authorities that they plan to require IFRS reporting for domestic firms. (2) Late Voluntary indicates the subset of firms voluntarily switching to IFRS after local authorities have announced their plans to require IFRS reporting for domestic firms. First-Time Mandatory indicates firm-years ending on or after the local date for mandated IFRS reporting and applies only to firms that have never reported under IFRS before (i.e., it excludes mandated IFRS observations from voluntary IFRS adopter firms). We form a separate category, U.S. Listing, for non-U.S. companies whose shares are traded over-thecounter or listed on a U.S. exchange (see Hail and Leuz [2008]). Note that these observations are not included in the U.S. GAAP indicator. New Markets observations stem from firms traded on an exchange that specializes in technology or other high-growth stocks and has listing requirements mandating or allowing financial reports according to IFRS, i.e., Bovespa Novo Mercado (Brazil), Expandi market (Italy), Hercules and Mothers (Japan), Irish Enterprise Exchange (Ireland), Market for Alternative Investment (Thailand), Mesdaq (Malaysia), Neuer Markt (Germany), Nordic Growth Market (Sweden), Nuevo Mercado (Spain), NZAX Market (New Zealand), and Sesdaq (Singapore). Index Member represents firms whose shares are constituents of national or international stock market indices as defined in Worldscope (Field 05661). Note that this variable is only available for the most recent fiscal year in Worldscope and therefore is time-invariant. 
TABLE 2

Descriptive Statistics for Variables Used in Regression Analyses

Panel A: Dependent Variables

\begin{tabular}{|c|c|c|c|c|c|c|c|c|}
\hline Variables & $N$ & Mean & Std. Dev. & $P 1$ & $P 25$ & Median & P75 & $P 99$ \\
\hline Zero Returns & 105,527 & $29.2 \%$ & $24.7 \%$ & $0.0 \%$ & $9.6 \%$ & $19.7 \%$ & $44.6 \%$ & $91.5 \%$ \\
\hline Price Impact & 102,119 & 4.839 & 15.618 & 0.000 & 0.022 & 0.219 & 1.880 & 89.827 \\
\hline Total Trading Costs & 94,759 & $6.5 \%$ & $7.3 \%$ & $0.5 \%$ & $2.1 \%$ & $3.7 \%$ & $7.7 \%$ & $37.4 \%$ \\
\hline Bid-Ask Spread & 65,296 & $3.3 \%$ & $4.7 \%$ & $0.1 \%$ & $0.7 \%$ & $1.5 \%$ & $3.8 \%$ & $24.0 \%$ \\
\hline Cost of Capital & 24,913 & $10.2 \%$ & $3.4 \%$ & $5.1 \%$ & $7.9 \%$ & $9.4 \%$ & $11.7 \%$ & $21.9 \%$ \\
\hline Tobin's q & 97,293 & 1.438 & 0.957 & 0.526 & 0.923 & 1.116 & 1.580 & 5.657 \\
\hline
\end{tabular}

Panel B: Continuous Independent Variables

\begin{tabular}{|c|c|c|c|c|c|c|c|c|}
\hline Variables & $N$ & Mean & Std. Dev. & $P 1$ & $P 25$ & Median & P75 & $P 99$ \\
\hline Market Value & 105,527 & 601.1 & $1,704.1$ & 0.8 & 20.9 & 78.7 & 338.2 & $9,813.9$ \\
\hline Share Turnover & 105,527 & 0.921 & 1.566 & 0.004 & 0.126 & 0.376 & 0.977 & 8.490 \\
\hline Return Variability & 105,527 & 0.151 & 0.120 & 0.025 & 0.075 & 0.116 & 0.186 & 0.615 \\
\hline Risk-Free Rate & 105,071 & $3.0 \%$ & $2.8 \%$ & $0.1 \%$ & $1.2 \%$ & $2.5 \%$ & $4.0 \%$ & $16.0 \%$ \\
\hline Total Assets & 104,844 & $1,273.5$ & $4,102.0$ & 0.4 & 43.8 & 163.7 & 626.7 & $22,195.7$ \\
\hline Financial Leverage & 99,823 & 0.504 & 0.252 & 0.014 & 0.310 & 0.510 & 0.691 & 0.965 \\
\hline Forecast Bias & 44,097 & 0.009 & 0.042 & -0.076 & -0.004 & 0.000 & 0.011 & 0.206 \\
\hline Asset Growth & 103,171 & $10.0 \%$ & $46.9 \%$ & $-52.7 \%$ & $-6.0 \%$ & $3.1 \%$ & $14.6 \%$ & $201.1 \%$ \\
\hline Industry q & 105,527 & 1.218 & 0.273 & 0.942 & 1.034 & 1.115 & 1.288 & 2.136 \\
\hline
\end{tabular}

The full sample comprises a maximum of 105,527 firm-year observations from 51 countries between 2001 and 2005 with financial data from Worldscope and price/volume data from Datastream. The table reports descriptive statistics for the dependent variables (Panel A) and the continuous independent variables (Panel B). We use six dependent variables in our primary analyses: (1) Zero Returns is the proportion of trading days with zero daily stock returns out of all potential trading days in a given year. (2) Price Impact is the yearly median of the Amihud [2002] illiquidity measure (i.e., daily absolute stock return divided by US\$ trading volume). (3) Total Trading Costs is a yearly estimate of total round-trip transaction costs (i.e., bid-ask spreads, commissions as well as implicit costs such as short-sale constraints or taxes) inferred from the series of daily security and aggregate market returns, as developed by Lesmond, Ogden, and Trzcinka [1999]. (4) The Bid-Ask Spread is the yearly median quoted spread (i.e., difference between the bid and ask price divided by the mid-point and measured at the end of each trading day). (5) Cost of Capital is the average cost of capital estimate implied by the mean I/B/E/S analyst consensus forecasts and stock prices using the Claus and Thomas [2001] model, the Gebhardt, Lee, and Swaminathan [2001] model, the Ohlson and Juettner-Nauroth [2005] model and the Easton [2004] model. (6) We compute Tobin's $q$ as (total assets - book value of equity + market value of equity)/total assets. In the Appendix, we describe the measurement of the dependent variables in more detail. The continuous independent variables consist of the following measures: Market Value is stock price times the number of shares outstanding (in US\$ millions). Share Turnover is annual US\$ trading volume divided by market value of outstanding equity. We compute Return Variability as annual standard deviation of monthly stock returns. Risk-Free Rate is the yearly median of the nominal local yields on short-term treasury bills, central bank papers or inter-bank loans, as reported in Datastream. Total Assets are denominated in US\$ millions. We compute Financial Leverage as the ratio of total liabilities to total assets. Forecast Bias equals last year's one-year-ahead I/B/E/S mean analyst consensus forecast minus this year's actual earnings, scaled by lagged total assets. We compute Asset Growth as the one-year percentage change in total assets. Industry $q$ is the yearly median Tobin's q in a given Campbell [1996] industry. Accounting data and market values are measured as of the fiscal-year end, the liquidity variables, cost of capital, share turnover, return variability and forecast bias as of month +7 after the fiscal-year end. Except for variables with natural lower or upper bounds, we truncate all variables at the first and 99th percentile. 
TABLE 3

Difference-in-Differences Analysis of the Capital-Market Effects around the IFRS Mandate

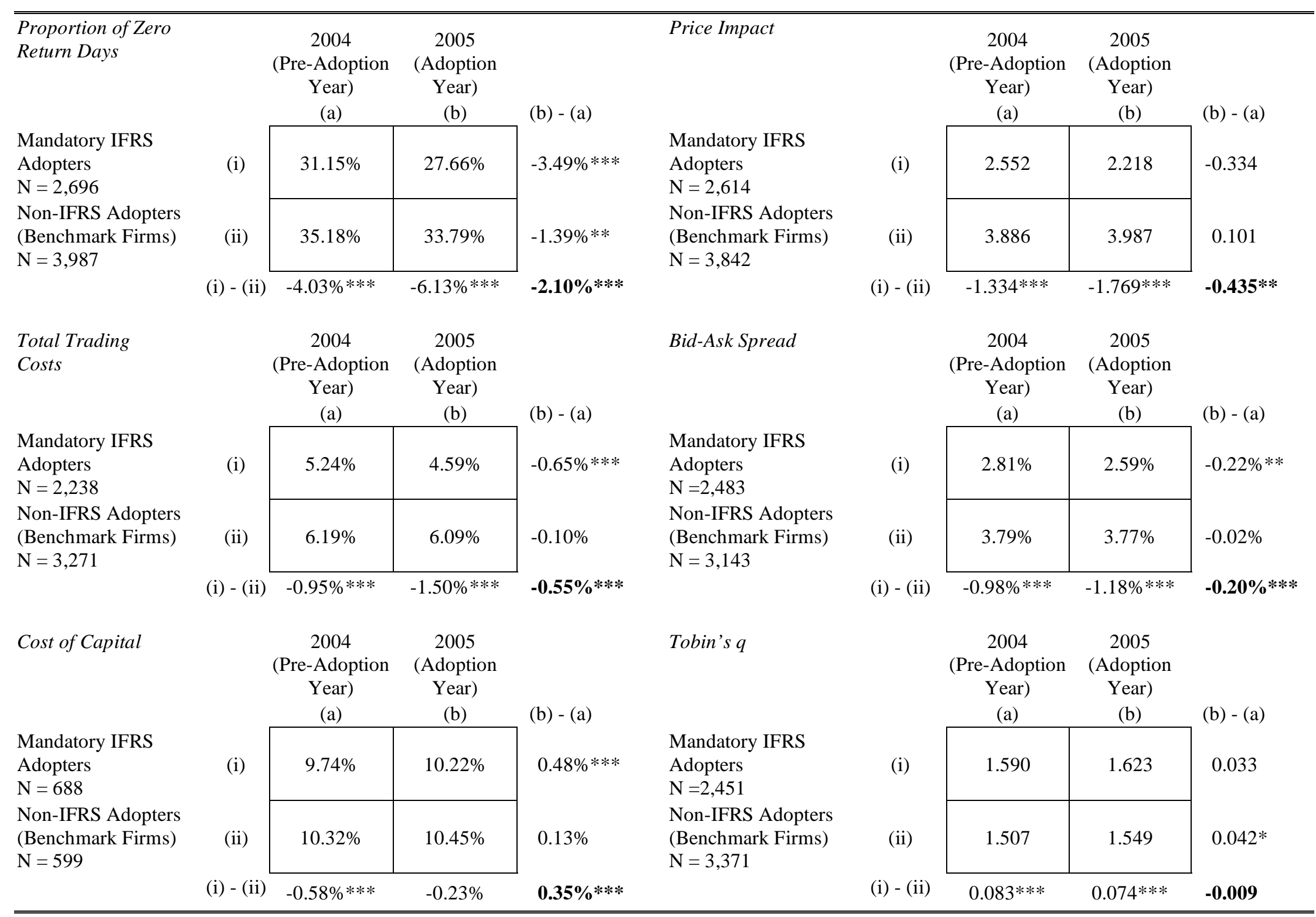


The difference-in-differences analysis is based on all mandatory IFRS adopters and randomly selected benchmark companies with data available in 2004 and 2005 (i.e., pre-adoption versus adoption year), thereby holding the sample composition constant and fixing the time period. The table reports mean values of the dependent variables and the number of observations. Note that we only include treatment sample countries where IFRS reporting became mandatory on December 31, 2005, and exclude all voluntary IFRS adoption firms. We use six dependent variables in the analyses: (1) Zero Returns is the proportion of trading days with zero daily stock returns out of all potential trading days in a given year. (2) Price Impact is the yearly median of the Amihud [2002] illiquidity measure. (3) Total Trading Costs is the Lesmond, Ogden, and Trzcinka [1999] yearly estimate of total round-trip transaction costs. (4) Bid-Ask Spread is the yearly median quoted spread. (5) Cost of Capital is the mean of four estimates for the implied cost of equity capital. (6) Tobin's q equals (total assets - book value of equity + market value of equity)/total assets. See the Appendix for details. $* * *, * *$, and $*$ indicate statistical significance of differences in means at the $1 \%, 5 \%$, and $10 \%$ levels, respectively, based on two-sided t-tests. We assess the statistical significance of the difference-in-differences values (i.e., the lower left-hand side number in each panel) by comparing means of yearly firm-level changes across IFRS and non-IFRS adopters using t-tests. 


\section{TABLE 4}

Firm-Year Regression Analysis of the Liquidity Effects around the IFRS Mandate

Panel A: Base Model (i.e., Firms from IFRS Adoption Countries and Randomly Selected Worldwide Benchmark Sample)

\begin{tabular}{|c|c|c|c|c|c|}
\hline \multirow[b]{2}{*}{ Independent Variables } & \multicolumn{5}{|c|}{ Various Liquidity Measures as Dependent Variable } \\
\hline & $\begin{array}{c}\text { Proportion of Zero } \\
\text { Return Days }\end{array}$ & $\log ($ Price Impact $)$ & $\begin{array}{c}\log (\text { Total } \\
\text { Trading Costs }) \\
\end{array}$ & $\begin{array}{c}\log (\text { Bid-Ask } \\
\text { Spread })\end{array}$ & $\begin{array}{l}\text { Liquidity } \\
\text { Factor }\end{array}$ \\
\hline \multicolumn{6}{|l|}{ IFRS Adopter Types: } \\
\hline Early Voluntary & $\begin{array}{c}0.07 \\
(0.08)\end{array}$ & $\begin{array}{c}-10.05 \\
(-1.00)\end{array}$ & $\begin{array}{c}0.75 \\
(0.18)\end{array}$ & $\begin{array}{c}-5.47 \\
(-1.20)\end{array}$ & $\begin{array}{c}3.31 \\
(1.09)\end{array}$ \\
\hline Late Voluntary & $\begin{array}{l}-2.95 * * * \\
(-3.23)\end{array}$ & $\begin{array}{l}-19.84 * * * \\
(-2.72)\end{array}$ & $\begin{array}{l}-11.84 * * * \\
(-3.32)\end{array}$ & $\begin{array}{l}-16.92 * * * \\
(-4.69)\end{array}$ & $\begin{array}{l}-7.81 * * \\
(-2.52)\end{array}$ \\
\hline Early Voluntary*Mandatory & $\begin{array}{c}-0.96 * \\
(-1.95)\end{array}$ & $\begin{array}{l}-21.75 * * * \\
(-4.45)\end{array}$ & $\begin{array}{l}-15.54 * * * \\
(-6.05)\end{array}$ & $\begin{array}{l}-16.04 * * * \\
(-6.37)\end{array}$ & $\begin{array}{l}-4.04 * * \\
(-2.16)\end{array}$ \\
\hline Late Voluntary*Mandatory & $\begin{array}{c}-0.93 \\
(-1.11)\end{array}$ & $\begin{array}{c}-3.63 \\
(-0.41)\end{array}$ & $\begin{array}{l}-9.31 * * \\
(-1.96)\end{array}$ & $\begin{array}{c}0.92 \\
(0.21)\end{array}$ & $\begin{array}{l}-3.64 \\
(-1.17)\end{array}$ \\
\hline First-Time Mandatory & $\begin{array}{l}-1.00 * * * \\
(-3.13)\end{array}$ & $\begin{array}{c}1.21 \\
(0.43)\end{array}$ & $\begin{array}{l}-2.99 * * \\
(-2.30)\end{array}$ & $\begin{array}{l}-6.57 * * * \\
(-4.76)\end{array}$ & $\begin{array}{l}-4.41 * * * \\
(-3.52)\end{array}$ \\
\hline \multicolumn{6}{|l|}{ Control Variables: } \\
\hline U.S. GAAP & $\begin{array}{c}-0.34 \\
(-0.42)\end{array}$ & $\begin{array}{c}0.86 \\
(0.10)\end{array}$ & $\begin{array}{l}11.24 * * * \\
(2.65)\end{array}$ & $\begin{array}{c}-4.94 \\
(-1.30)\end{array}$ & $\begin{array}{c}-0.51 \\
(-0.19)\end{array}$ \\
\hline U.S. Listing & $\begin{array}{l}-0.17 \\
(-0.15)\end{array}$ & $\begin{array}{c}9.11 \\
(0.88)\end{array}$ & $\begin{array}{l}-0.28 \\
(-0.05)\end{array}$ & $\begin{array}{c}8.07 \\
(1.06)\end{array}$ & $\begin{array}{c}1.42 \\
(0.29)\end{array}$ \\
\hline New Markets & $\begin{array}{l}-5.79 * \\
(-1.96)\end{array}$ & $\begin{array}{l}-11.48 \\
(-0.55)\end{array}$ & $\begin{array}{l}-10.39 \\
(-0.97)\end{array}$ & $\begin{array}{l}-5.76 \\
(-0.54)\end{array}$ & $\begin{array}{l}-31.74 * * \\
(-2.23)\end{array}$ \\
\hline $\log \left(\right.$ Market Value $\left._{t-1}\right)$ & $\begin{array}{l}-3.38 * * * \\
(-22.48)\end{array}$ & $\begin{array}{l}-41.16 * * * \\
(-29.85)\end{array}$ & $\begin{array}{l}-13.24 * * * \\
(-22.99)\end{array}$ & $\begin{array}{l}-13.11 * * * \\
(-20.39)\end{array}$ & $\begin{array}{l}-11.22 * * * \\
(-19.18)\end{array}$ \\
\hline $\log \left(\right.$ Share Turnover $\left.{ }_{t-1}\right)$ & $\begin{array}{l}-2.38 * * * \\
(-21.84)\end{array}$ & $\begin{array}{l}-33.49 * * * \\
(-33.08)\end{array}$ & $\begin{array}{l}-10.38 * * * \\
(-22.97)\end{array}$ & $\begin{array}{l}-13.12 * * * \\
(-26.77)\end{array}$ & $\begin{array}{l}-8.26 * * * \\
(-17.80)\end{array}$ \\
\hline $\log \left(\right.$ Return Variability $\left._{t-1}\right)$ & $\begin{array}{l}-1.85 * * * \\
(-9.49)\end{array}$ & $\begin{array}{l}-6.82 * * * \\
(-4.06)\end{array}$ & $\begin{array}{c}1.12 \\
(1.37)\end{array}$ & $\begin{array}{l}2.11 * * \\
(2.55)\end{array}$ & $\begin{array}{l}-3.89 * * * \\
(-5.07)\end{array}$ \\
\hline Market Benchmark & $\begin{array}{c}105.69 * * * \\
(4.90)\end{array}$ & $\begin{array}{l}124.30 * * * \\
(13.78)\end{array}$ & $\begin{array}{l}60.44 * * * \\
(5.70)\end{array}$ & $\begin{array}{l}41.25 * * * \\
(6.42)\end{array}$ & $\begin{array}{l}53.58 * * * \\
(3.63)\end{array}$ \\
\hline Fixed Effects & $\begin{array}{c}\text { Firm/ } \\
\text { Industry-Year }\end{array}$ & $\begin{array}{c}\text { Firm/ } \\
\text { Industry-Year }\end{array}$ & $\begin{array}{c}\text { Firm/ } \\
\text { Industry-Year }\end{array}$ & $\begin{array}{c}\text { Firm/ } \\
\text { Industry-Year }\end{array}$ & $\begin{array}{c}\text { Firm/ } \\
\text { Industry-Year }\end{array}$ \\
\hline $\mathrm{R}^{2}$ & 0.90 & 0.94 & 0.90 & 0.92 & 0.86 \\
\hline \# Observations & 43,999 & 42,492 & 37,611 & 37,712 & 31,407 \\
\hline \# Unique Firms & 11,077 & 10,806 & 10,173 & 9,648 & 8,622 \\
\hline \# Countries & 51 & 51 & 48 & 38 & 36 \\
\hline
\end{tabular}


TABLE 4 - Continued

Panel B: Sensitivity Analyses

\begin{tabular}{|c|c|c|c|c|c|c|}
\hline IFRS Adopter Type Variables & $\begin{array}{c}\text { Model 1: } \\
\text { IFRS Adoption } \\
\text { Countries } \\
\text { only }\end{array}$ & $\begin{array}{c}\text { Model 2: } \\
\text { IFRS Adoption } \\
\text { Countries plus } \\
\text { U.S. as } \\
\text { Benchmark } \\
\text { Sample }\end{array}$ & $\begin{array}{c}\text { Model 3: } \\
\text { IFRS Adoption } \\
\text { Countries plus } \\
\text { Complete World- } \\
\text { wide Benchmark } \\
\text { Sample }\end{array}$ & $\begin{array}{c}\text { Model 4: } \\
\text { Base Model, } \\
\text { with Constant } \\
\text { Sample over } \\
\text { Time }\end{array}$ & $\begin{array}{c}\text { Model 5: } \\
\text { Base Model, } \\
\text { but only IFRS } \\
\text { Adopters from } \\
\text { Treatment } \\
\text { Countries }\end{array}$ & $\begin{array}{c}\text { Model 6: } \\
\text { Base Model, } \\
\text { with Country- } \\
\text { Fixed instead of } \\
\text { Firm-Fixed } \\
\text { Effects }\end{array}$ \\
\hline \multicolumn{7}{|c|}{ Proportion of Zero Return Days as Dependent Variable: } \\
\hline Early Voluntary & $\begin{array}{c}0.08 \\
(0.10)\end{array}$ & $\begin{array}{c}0.38 \\
(0.44)\end{array}$ & $\begin{array}{c}0.10 \\
(0.11)\end{array}$ & $\begin{array}{c}0.23 \\
(0.26)\end{array}$ & $\begin{array}{c}-0.16 \\
(-0.18)\end{array}$ & $\begin{array}{l}-1.90 * * * \\
(-2.98)\end{array}$ \\
\hline Late Voluntary & $\begin{array}{l}-2.98 * * * \\
(-3.26)\end{array}$ & $\begin{array}{l}-2.93 * * * \\
(-3.19)\end{array}$ & $\begin{array}{l}-2.50 * * * \\
(-2.77)\end{array}$ & $\begin{array}{l}-2.63 * * * \\
(-3.17)\end{array}$ & $\begin{array}{l}-3.44 * * * \\
(-3.31)\end{array}$ & $\begin{array}{l}-3.91 * * * \\
(-3.85)\end{array}$ \\
\hline Early Voluntary*Mandatory & $\begin{array}{c}0.45 \\
(0.85)\end{array}$ & $\begin{array}{l}-1.87 * * * \\
(-4.00)\end{array}$ & $\begin{array}{l}-1.89 * * * \\
(-4.18)\end{array}$ & $\begin{array}{c}-0.94 * \\
(-1.86)\end{array}$ & $\begin{array}{l}-2.28 * * * \\
(-4.37)\end{array}$ & $\begin{array}{c}-0.17 \\
(-0.29)\end{array}$ \\
\hline Late Voluntary*Mandatory & $\begin{array}{c}0.53 \\
(0.63)\end{array}$ & $\begin{array}{l}-1.61^{*} \\
(-1.91)\end{array}$ & $\begin{array}{l}-2.00 * * \\
(-2.41)\end{array}$ & $\begin{array}{c}-0.79 \\
(-0.90)\end{array}$ & $\begin{array}{l}-2.04 * * \\
(-2.42)\end{array}$ & $\begin{array}{c}0.83 \\
(0.75)\end{array}$ \\
\hline First-Time Mandatory & $\begin{array}{c}0.36 \\
(1.03)\end{array}$ & $\begin{array}{l}-1.74 * * * \\
(-6.08)\end{array}$ & $\begin{array}{l}-1.86 * * * \\
(-6.78)\end{array}$ & $\begin{array}{l}-0.97 * * * \\
(-2.86)\end{array}$ & $\begin{array}{l}-2.20 * * * * \\
(-6.20)\end{array}$ & $\begin{array}{l}-0.96 * * * \\
(-2.97)\end{array}$ \\
\hline \multicolumn{7}{|c|}{ Log(Total Trading Costs) as Dependent Variable: } \\
\hline Early Voluntary & $\begin{array}{c}0.01 \\
(0.00)\end{array}$ & $\begin{array}{c}0.73 \\
(0.18)\end{array}$ & $\begin{array}{l}1.65 \\
(0.41)\end{array}$ & $\begin{array}{c}2.53 \\
(0.56)\end{array}$ & $\begin{array}{c}1.29 \\
(0.29)\end{array}$ & $\begin{array}{c}-3.29 \\
(-1.49)\end{array}$ \\
\hline Late Voluntary & $\begin{array}{l}-11.65 * * * \\
(-3.29)\end{array}$ & $\begin{array}{l}-10.06 * * * \\
(-2.82)\end{array}$ & $\begin{array}{l}-11.13^{* * *} \\
(-3.14)\end{array}$ & $\begin{array}{l}-10.23 * * * \\
(-2.70)\end{array}$ & $\begin{array}{l}-12.83 * * * \\
(-3.17)\end{array}$ & $\begin{array}{l}-12.60 * * * \\
(-3.73)\end{array}$ \\
\hline Early Voluntary*Mandatory & $\begin{array}{l}-10.48 * * * * \\
(-3.94)\end{array}$ & $\begin{array}{l}-11.57 * * * \\
(-4.72)\end{array}$ & $\begin{array}{l}-14.51 * * * * \\
(-6.04)\end{array}$ & $\begin{array}{l}-15.08 * * * \\
(-5.59)\end{array}$ & $\begin{array}{l}-18.07 * * * * \\
(-6.66)\end{array}$ & $\begin{array}{l}-10.44 * * * \\
(-3.97)\end{array}$ \\
\hline Late Voluntary*Mandatory & $\begin{array}{c}-4.90 \\
(-1.03)\end{array}$ & $\begin{array}{c}-6.09 \\
(-1.31)\end{array}$ & $\begin{array}{c}-8.13 * \\
(-1.77)\end{array}$ & $\begin{array}{l}-12.05 * * \\
(-2.41)\end{array}$ & $\begin{array}{l}-11.09 * * \\
(-2.26)\end{array}$ & $\begin{array}{c}-2.89 \\
(-0.53)\end{array}$ \\
\hline First-Time Mandatory & $\begin{array}{c}1.64 \\
(1.14)\end{array}$ & $\begin{array}{c}1.05 \\
(0.94)\end{array}$ & $\begin{array}{c}-1.82 * \\
(-1.72)\end{array}$ & $\begin{array}{c}-1.95 \\
(-1.38)\end{array}$ & $\begin{array}{l}-5.15 * * * \\
(-3.39)\end{array}$ & $\begin{array}{c}-2.80 * \\
(-1.94)\end{array}$ \\
\hline \multicolumn{7}{|c|}{ Liquidity Factor as Dependent Variable: } \\
\hline Early Voluntary & $\begin{array}{c}3.21 \\
(1.04)\end{array}$ & $\begin{array}{c}2.85 \\
(0.92)\end{array}$ & $\begin{array}{c}2.02 \\
(0.60)\end{array}$ & $\begin{array}{c}-1.40 \\
(-0.42)\end{array}$ & $\begin{array}{l}1.20 \\
(0.35)\end{array}$ & $\begin{array}{l}-5.08 * * * \\
(-2.64)\end{array}$ \\
\hline Late Voluntary & $\begin{array}{l}-7.15^{* *} \\
(-2.32)\end{array}$ & $\begin{array}{l}-7.69 * * \\
(-2.47)\end{array}$ & $\begin{array}{c}-6.43^{*} \\
(-1.91)\end{array}$ & $\begin{array}{l}-11.07 * * * \\
(-2.89)\end{array}$ & $\begin{array}{l}-8.91 * * \\
(-2.44)\end{array}$ & $\begin{array}{l}-10.62 * * * \\
(-3.73)\end{array}$ \\
\hline Early Voluntary*Mandatory & $\begin{array}{c}0.15 \\
(0.07)\end{array}$ & $\begin{array}{c}0.57 \\
(0.29)\end{array}$ & $\begin{array}{l}-3.66 * \\
(-1.95)\end{array}$ & $\begin{array}{c}-1.61 \\
(-0.81)\end{array}$ & $\begin{array}{l}-8.99 * * * \\
(-4.32)\end{array}$ & $\begin{array}{l}-4.46 * * \\
(-2.25)\end{array}$ \\
\hline Late Voluntary*Mandatory & $\begin{array}{c}0.18 \\
(0.06)\end{array}$ & $\begin{array}{c}0.39 \\
(0.12)\end{array}$ & $\begin{array}{c}-4.85 \\
(-1.46)\end{array}$ & $\begin{array}{c}0.09 \\
(0.02)\end{array}$ & $\begin{array}{l}-8.15 * * \\
(-2.56)\end{array}$ & $\begin{array}{c}-0.22 \\
(-0.05)\end{array}$ \\
\hline First-Time Mandatory & $\begin{array}{c}-0.23 \\
(-0.17)\end{array}$ & $\begin{array}{c}-0.05 \\
(-0.04)\end{array}$ & $\begin{array}{l}-4.46 * * * \\
(-3.75)\end{array}$ & $\begin{array}{c}-0.98 \\
(-0.71)\end{array}$ & $\begin{array}{l}-9.27 * * * \\
(-6.18)\end{array}$ & $\begin{array}{l}-5.29 * * * \\
(-4.42)\end{array}$ \\
\hline \# Observations (Zero Returns) & 34,673 & 64,101 & 105,527 & 29,410 & 27,759 & 43,999 \\
\hline
\end{tabular}


The sample comprises firm-year observations from up to 51 countries between 2001 and 2005 (see Table 1). Panel A reports our primary specification (i.e., the treatment sample combined with a maximum of 150 randomly selected firms from each benchmark sample country) across five liquidity measures as dependent variables: (1) Zero Returns is the proportion of trading days with zero daily stock returns out of all potential trading days in a given year. (2) Price Impact is the yearly median of the Amihud [2002] illiquidity measure. (3) Total Trading Costs is the Lesmond, Ogden, and Trzcinka [1999] yearly estimate of total round-trip transaction costs. (4) Bid-Ask Spread is the yearly median quoted spread. (5) Liquidity Factor summarizes our liquidity proxies and represents the scores of a single factor extracted from the liquidity variables (1) through (4) employing factor analysis with one oblique rotation. In Panel B, we report selected sensitivity analyses for Zero Returns, Total Trading Costs and the Liquidity Factor across the following six specifications: Model 1 uses IFRS and non-IFRS observations from the treatment sample only (i.e., excluding the benchmark sample). In Model 2, we combine the treatment sample with all U.S. firm-year observations. Model 3 uses the complete worldwide benchmark sample. In Model 4, we hold the sample composition in the Base Model (Panel A) constant and include only firms with a complete time-series of observations over the entire sample period. Model 5 limits the treatment sample to firms with at least one IFRS observation. That is, we exclude (control) firms from treatment countries that have not yet switched to IFRS. In Model 6 we use the base model, but replace the firm-fixed effects by country-fixed effects. We classify IFRS observations into three distinctive categories using binary indicator variables: (1) Early Voluntary marks the subset of firms voluntarily switching to IFRS prior to the announcement by local authorities that they plan to require IFRS reporting for domestic firms. (2) Late Voluntary indicates the subset of firms voluntarily switching to IFRS after local authorities have announced their plans to require IFRS reporting for domestic firms. (3) First-Time Mandatory indicates firm-years ending after IFRS adoption becomes mandatory and applies only to firms that have never reported under IFRS before. To capture the incremental effect of the IFRS mandate on voluntary adopters, we introduce another binary indicator variable, Mandatory, that takes on the value of one for firm-years ending on or after the local adoption date for mandatory IFRS reporting and interact it with Early Voluntary and Late Voluntary, respectively. In each regression, we include a Market Benchmark defined as yearly mean of the dependent variable from observations in countries that do not mandate IFRS adoption (i.e., the benchmark sample). For a description of the remaining control variables see Table 1 (indicator variables) and Table 2 (continuous variables). We use the natural log of the raw values and lag the variables by one year where indicated in the panels. We include an intercept, industry-year-fixed effects based on the industry classification in Campbell [1996] and, depending on the model specification, firm- or country-fixed effects in the regressions but do not report these coefficients. Panel B shows only the IFRS adopter type variables but the reported coefficients stem from estimating the full model with the controls shown in Panel A. The table reports OLS coefficient estimates and (in parentheses) tstatistics based on robust standard errors that are clustered by firm. For expositional purposes we multiply all coefficients by 100 . $* * *, * *$, and $*$ indicate statistical significance at the $1 \%, 5 \%$, and $10 \%$ levels (two-tailed), respectively. 
TABLE 5

Firm-Year Regression Analysis of the Cost of Capital and Valuation Effects around the IFRS Mandate

\begin{tabular}{|c|c|c|c|c|c|c|}
\hline \multirow[b]{2}{*}{ Independent Variables } & \multicolumn{3}{|c|}{ Cost of Capital as Dependent Variable } & \multicolumn{3}{|c|}{ Tobin's q as Dependent Variable } \\
\hline & $\begin{array}{c}\text { Model 1: } \\
\text { IFRS Adoption } \\
\text { Countries plus } \\
\text { Random Bench- } \\
\text { mark Sample }\end{array}$ & $\begin{array}{c}\text { Model 2: } \\
\text { Base Model, but } \\
\text { Excluding Year } \\
\text { before Manda- } \\
\text { tory Adoption }\end{array}$ & $\begin{array}{c}\text { Model 3: } \\
\text { Base Model, but } \\
\text { Shifting Man- } \\
\text { datory Adoption } \\
\text { by one Year }\end{array}$ & $\begin{array}{c}\text { Model 1: } \\
\text { IFRS Adoption } \\
\text { Countries plus } \\
\text { Random Bench- } \\
\text { mark Sample }\end{array}$ & $\begin{array}{c}\text { Model 2: } \\
\text { Base Model, but } \\
\text { Excluding Year } \\
\text { before Manda- } \\
\text { tory Adoption }\end{array}$ & $\begin{array}{c}\text { Model 3: } \\
\text { Base Model, but } \\
\text { Shifting Man- } \\
\text { datory Adoption } \\
\text { by one Year }\end{array}$ \\
\hline \multicolumn{7}{|l|}{ IFRS Adopter Types: } \\
\hline Early Voluntary & $\begin{array}{c}0.49 \\
(0.82)\end{array}$ & $\begin{array}{c}0.74 \\
(0.95)\end{array}$ & $\begin{array}{c}0.84 \\
(1.36)\end{array}$ & $\begin{array}{c}5.43 \\
(0.77)\end{array}$ & $\begin{array}{c}3.09 \\
(0.35)\end{array}$ & $\begin{array}{c}-1.35 \\
(-0.19)\end{array}$ \\
\hline Late Voluntary & $\begin{array}{c}-0.16 \\
(-0.44)\end{array}$ & $\begin{array}{c}0.13 \\
(0.28)\end{array}$ & $\begin{array}{c}0.34 \\
(0.74)\end{array}$ & $\begin{array}{l}12.26^{* * *} \\
(2.27)\end{array}$ & $\begin{array}{c}9.59 \\
(1.59)\end{array}$ & $\begin{array}{c}11.06^{*} \\
(1.95)\end{array}$ \\
\hline Early Voluntary*Mandatory & $\begin{array}{c}0.37 \\
(1.45)\end{array}$ & $\begin{array}{c}-0.21 \\
(-0.60)\end{array}$ & $\begin{array}{l}-0.66 * * * \\
(-2.76)\end{array}$ & $\begin{array}{c}-4.31 \\
(-1.08)\end{array}$ & $\begin{array}{c}4.75 \\
(0.99)\end{array}$ & $\begin{array}{l}14.31 * * * \\
(4.11)\end{array}$ \\
\hline Late Voluntary*Mandatory & $\begin{array}{c}0.41 \\
(1.12)\end{array}$ & $\begin{array}{c}-0.31 \\
(-0.59)\end{array}$ & $\begin{array}{l}-0.90 * * \\
(-2.08)\end{array}$ & $\begin{array}{l}-13.60 * * \\
(-2.19)\end{array}$ & $\begin{array}{c}-4.87 \\
(-0.60)\end{array}$ & $\begin{array}{c}2.67 \\
(0.48)\end{array}$ \\
\hline First-Time Mandatory & $\begin{array}{l}0.67 * * * \\
(4.48)\end{array}$ & $\begin{array}{c}0.23 \\
(0.95)\end{array}$ & $\begin{array}{l}-0.26 * * \\
(-2.04)\end{array}$ & $\begin{array}{l}-4.57 * * \\
(-2.51)\end{array}$ & $\begin{array}{c}3.31 \\
(1.41)\end{array}$ & $\begin{array}{l}8.05 * * * \\
(5.74)\end{array}$ \\
\hline \multicolumn{7}{|l|}{ Control Variables: } \\
\hline U.S. GAAP & $\begin{array}{c}0.05 \\
(0.09)\end{array}$ & $\begin{array}{c}-0.35 \\
(-0.55)\end{array}$ & $\begin{array}{c}-0.02 \\
(-0.05)\end{array}$ & $\begin{array}{l}7.36 \\
(1.00)\end{array}$ & $\begin{array}{l}5.65 \\
(0.74)\end{array}$ & $\begin{array}{c}8.14 \\
(1.11)\end{array}$ \\
\hline U.S. Listing & $\begin{array}{c}-0.28 \\
(-0.64)\end{array}$ & $\begin{array}{c}-0.20 \\
(-0.45)\end{array}$ & $\begin{array}{c}-0.32 \\
(-0.71)\end{array}$ & $\begin{array}{c}6.48 \\
(0.79)\end{array}$ & $\begin{array}{c}3.19 \\
(0.33)\end{array}$ & $\begin{array}{c}6.29 \\
(0.77)\end{array}$ \\
\hline New Markets & $\begin{array}{c}0.57 * \\
(1.73)\end{array}$ & $\begin{array}{c}0.65 \\
(1.64)\end{array}$ & $\begin{array}{c}0.30 \\
(0.89)\end{array}$ & $\begin{array}{l}34.51 \\
(0.97)\end{array}$ & $\begin{array}{l}26.29 \\
(0.73)\end{array}$ & $\begin{array}{l}36.09 \\
(1.03)\end{array}$ \\
\hline Log(Total Assets) & $\begin{array}{l}0.59 * * * \\
(3.20)\end{array}$ & $\begin{array}{l}0.62 * * * \\
(2.69)\end{array}$ & $\begin{array}{l}0.49 * * * \\
(2.70)\end{array}$ & $\begin{array}{l}-41.96 * * * \\
(-15.62)\end{array}$ & $\begin{array}{l}-42.33 * * * \\
(-14.02)\end{array}$ & $\begin{array}{l}-41.58 * * * \\
(-15.61)\end{array}$ \\
\hline Financial Leverage & $\begin{array}{l}1.35^{* *} \\
(2.08)\end{array}$ & $\begin{array}{c}0.69 \\
(0.89)\end{array}$ & $\begin{array}{l}1.35^{* * *} \\
(2.09)\end{array}$ & $\begin{array}{l}37.49 * * * \\
(5.69)\end{array}$ & $\begin{array}{l}40.83 * * * \\
(5.61)\end{array}$ & $\begin{array}{l}37.52 * * * \\
(5.71)\end{array}$ \\
\hline Risk-Free Rate & $\begin{array}{l}28.64 * * * \\
(6.18)\end{array}$ & $\begin{array}{l}18.08 * * * \\
(3.26)\end{array}$ & $\begin{array}{l}24.06 * * * \\
(5.09)\end{array}$ & - & - & - \\
\hline Return Variability & $\begin{array}{c}2.15 \\
(1.62)\end{array}$ & $\begin{array}{l}1.89 \\
(1.24)\end{array}$ & $\begin{array}{c}2.09 \\
(1.58)\end{array}$ & - & - & - \\
\hline Forecast Bias & $\begin{array}{l}7.53 * * * \\
(4.95)\end{array}$ & $\begin{array}{l}7.30 * * * \\
(3.97)\end{array}$ & $\begin{array}{l}7.68 * * * \\
(5.05)\end{array}$ & - & - & - \\
\hline Asset Growth & - & - & - & $\begin{array}{l}16.23 * * * \\
(7.72)\end{array}$ & $\begin{array}{l}17.67 * * * \\
(7.57)\end{array}$ & $\begin{array}{l}15.76^{* * * *} \\
(7.56)\end{array}$ \\
\hline Industry q & - & - & - & $\begin{array}{l}10.90 \\
(0.46)\end{array}$ & $\begin{array}{l}14.97 \\
(0.61)\end{array}$ & $\begin{array}{l}11.67 \\
(0.49)\end{array}$ \\
\hline Market Benchmark & $\begin{array}{c}252.98 * \\
(1.75)\end{array}$ & $\begin{array}{r}270.80 \\
(1.53)\end{array}$ & $\begin{array}{c}237.60 * \\
(1.65)\end{array}$ & $\begin{array}{c}431.77 * * * \\
(7.17)\end{array}$ & $\begin{array}{l}407.74 * * * \\
(6.53)\end{array}$ & $\begin{array}{l}409.14 * * * \\
(6.83)\end{array}$ \\
\hline Fixed Effects & $\begin{array}{c}\text { Firm/ } \\
\text { Industry-Year }\end{array}$ & $\begin{array}{c}\text { Firm/ } \\
\text { Industry-Year }\end{array}$ & $\begin{array}{c}\text { Firm/ } \\
\text { Industry-Year }\end{array}$ & $\begin{array}{c}\text { Firm/ } \\
\text { Industry-Year }\end{array}$ & $\begin{array}{c}\text { Firm/ } \\
\text { Industry-Year }\end{array}$ & $\begin{array}{c}\text { Firm/ } \\
\text { Industry-Year }\end{array}$ \\
\hline
\end{tabular}


TABLE 5 - Continued

\begin{tabular}{|c|c|c|c|c|c|c|}
\hline $\mathrm{R}^{2}$ & 0.80 & 0.82 & 0.80 & 0.77 & 0.79 & 0.77 \\
\hline \# Observations & 9,946 & 8,129 & 9,946 & 40,769 & 34,206 & 40,769 \\
\hline \# Unique Firms & 3,584 & 3,391 & 3,584 & 10,959 & 10,854 & 10,959 \\
\hline \# Countries & 36 & 36 & 36 & 47 & 47 & 47 \\
\hline
\end{tabular}

The sample comprises firm-year observations from up to 47 countries between 2001 and 2005. For each dependent variable, we report results across three model specifications: Model 1, the base model, combines the treatment sample with a maximum of 150 randomly selected firms from each benchmark sample country. In Model 2, we exclude the year immediately leading up to mandatory IFRS reporting from the treatment sample. For Model 3, we allow for the possibility that market participants anticipate the effects of mandatory IFRS reporting and price them one year ahead of the actual adoption (i.e., we shift the mandatory IFRS indicator variable by one year and code it as one in the year leading up to the mandatory change). We use two dependent variables in the analyses: Cost of Capital is the mean of four estimates for the implied cost of equity capital (Hail and Leuz [2006]), and Tobin's q equals (total assets - book value of equity + market value of equity)/total assets. See Appendix for details. We classify IFRS observations into three distinctive categories using binary indicator variables: (1) Early Voluntary marks the subset of firms voluntarily switching to IFRS prior to the announcement by local authorities that they plan to require IFRS reporting for domestic firms. (2) Late Voluntary indicates the subset of firms voluntarily switching to IFRS after local authorities have announced their plans to require IFRS reporting for domestic firms. (3) First-Time Mandatory indicates firm-years ending after IFRS adoption becomes mandatory and applies only to firms that have never reported under IFRS before. To capture the incremental effect of the IFRS mandate on voluntary adopters, we introduce another binary indicator variable, Mandatory, that takes on the value of one for firm-years ending on or after the local adoption date for mandatory IFRS reporting and interact it with Early Voluntary and Late Voluntary, respectively. In each regression, we include a Market Benchmark defined as yearly mean of the dependent variable from observations in countries that do not mandate IFRS adoption (i.e., the benchmark sample). For a description of the remaining control variables see Table 1 (indicator variables) and Table 2 (continuous variables). We use the natural log of the raw values and lag the variables by one year where indicated in the table. We include an intercept, industry-year-fixed effects based on the industry classification in Campbell [1996] and firm-fixed effects in the regressions but do not report the coefficients. The table reports OLS coefficient estimates and (in parentheses) t-statistics based on robust standard errors that are clustered by firm. For expositional purposes we multiply all coefficients by $100 . * * *, * *$, and $*$ indicate statistical significance at the $1 \%, 5 \%$, and $10 \%$ levels (two-tailed), respectively. 
TABLE 6

Institutional Characteristics of IFRS Adoption Countries and Industries

Panel A: Institutional Variables by IFRS Adoption Country

\begin{tabular}{|c|c|c|c|c|c|c|c|c|c|c|}
\hline \multirow{2}{*}{$\begin{array}{l}\text { IFRS Adoption } \\
\text { Countries } \\
\text { Australia }\end{array}$} & \multirow{2}{*}{$\begin{array}{c}\text { Announcement } \\
\text { of Mandatory } \\
\text { IFRS Reporting }\end{array}$} & \multirow{2}{*}{$\begin{array}{c}\begin{array}{c}\text { Adoption of } \\
\text { Mandatory }\end{array} \\
\text { IFRS Reporting } \\
12 / 31 / 2005\end{array}$} & \multicolumn{2}{|c|}{$\begin{array}{c}\text { Rule of } \\
\text { Law }\end{array}$} & \multirow{2}{*}{$\begin{array}{c}\text { Membership in } \\
\text { the European } \\
\text { Union } \\
0\end{array}$} & \multicolumn{2}{|c|}{$\begin{array}{c}\text { Aggregate } \\
\text { Earnings } \\
\text { Management }\end{array}$} & \multicolumn{2}{|c|}{$\begin{array}{c}\text { Difference } \\
\text { between Local } \\
\text { GAAP and IFRS }\end{array}$} & \multirow{2}{*}{$\begin{array}{c}\text { IFRS } \\
\text { Convergence } \\
\text { Strategy } \\
1\end{array}$} \\
\hline & & & 1.7 & (1) & & 5.9 & (1) & -0.4 & $(0)$ & \\
\hline Austria & 06/04/2002 & $12 / 31 / 2005$ & 1.8 & (1) & 1 & -4.9 & $(0)$ & 2.5 & (1) & 0 \\
\hline Belgium & 06/04/2002 & $12 / 31 / 2005$ & 1.4 & $(0)$ & 1 & -1.3 & $(0)$ & 1.4 & (1) & 0 \\
\hline Czech Republic & 06/04/2002 & $12 / 31 / 2005$ & 0.7 & $(0)$ & 1 & n.a. & n.a. & 0.6 & (1) & 0 \\
\hline Denmark & 06/04/2002 & $12 / 31 / 2005$ & 1.9 & (1) & 1 & -6.0 & $(0)$ & 0.1 & $(0)$ & 0 \\
\hline Finland & 06/04/2002 & $12 / 31 / 2005$ & 1.9 & (1) & 1 & -1.7 & $(0)$ & 4.4 & (1) & 0 \\
\hline France & 06/04/2002 & $12 / 31 / 2005$ & 1.3 & $(0)$ & 1 & 4.7 & (1) & 0.4 & (1) & 0 \\
\hline Germany & 06/04/2002 & $12 / 31 / 2005$ & 1.7 & (1) & 1 & 1.9 & (1) & 1.5 & (1) & 0 \\
\hline Greece & 06/04/2002 & $12 / 31 / 2005$ & 0.7 & $(0)$ & 1 & -9.2 & $(0)$ & 6.1 & (1) & 0 \\
\hline Hong Kong & 09/10/2004 & $12 / 31 / 2005$ & 1.5 & $(0)$ & 0 & -8.9 & $(0)$ & -1.5 & (0) & 1 \\
\hline Hungary & 06/04/2002 & $12 / 31 / 2005$ & 0.7 & (0) & 1 & n.a. & n.a. & -0.3 & $(0)$ & 0 \\
\hline Ireland & 06/04/2002 & $12 / 31 / 2005$ & 1.6 & (1) & 1 & 5.7 & (1) & -3.3 & $(0)$ & 0 \\
\hline Italy & 06/04/2002 & $12 / 31 / 2005$ & 0.5 & (0) & 1 & -6.2 & $(0)$ & 0.7 & (1) & 0 \\
\hline Luxembourg & 06/04/2002 & $12 / 31 / 2005$ & 1.9 & (1) & 1 & n.a. & n.a. & 6.0 & (1) & 0 \\
\hline The Netherlands & 06/04/2002 & $12 / 31 / 2005$ & 1.7 & (1) & 1 & 1.7 & (1) & -7.6 & $(0)$ & 0 \\
\hline Norway & 06/04/2002 & $12 / 31 / 2005$ & 1.9 & (1) & 0 & 4.2 & (1) & -3.8 & $(0)$ & 0 \\
\hline Philippines & $10 / 02 / 2003$ & $12 / 31 / 2005$ & -0.4 & (0) & 0 & 12.7 & $(1)$ & 1.1 & (1) & 1 \\
\hline Poland & 06/04/2002 & $12 / 31 / 2005$ & 0.3 & (0) & 1 & n.a. & n.a. & -0.9 & $(0)$ & 0 \\
\hline Portugal & 06/04/2002 & $12 / 31 / 2005$ & 1.1 & (0) & 1 & -6.0 & $(0)$ & 2.2 & (1) & 0 \\
\hline Singapore & $12 / 07 / 2000$ & $12 / 31 / 2003$ & 1.8 & (1) & 0 & -11.0 & $(0)$ & -4.5 & $(0)$ & 1 \\
\hline South Africa & $05 / 20 / 2003$ & $12 / 31 / 2005$ & 0.2 & (0) & 0 & 6.7 & (1) & -3.1 & $(0)$ & 1 \\
\hline Spain & 06/04/2002 & $12 / 31 / 2005$ & 1.1 & (0) & 1 & 0.2 & $(0)$ & 4.9 & (1) & 0 \\
\hline Sweden & 06/04/2002 & $12 / 31 / 2005$ & 1.8 & (1) & 1 & 3.4 & (1) & -0.7 & $(0)$ & 0 \\
\hline Switzerland & $11 / 11 / 2002$ & $12 / 31 / 2005$ & 2.0 & (1) & 0 & 1.0 & $(1)$ & 2.2 & (1) & 0 \\
\hline United Kingdom & 06/04/2002 & $12 / 31 / 2005$ & 1.6 & (1) & 1 & 3.7 & (1) & -3.4 & $(0)$ & 0 \\
\hline Venezuela & $04 / 21 / 2004$ & $12 / 31 / 2005$ & -1.3 & $(0)$ & 0 & n.a. & n.a. & -4.9 & $(0)$ & 0 \\
\hline
\end{tabular}

Panel B: Proportion of Voluntary IFRS Adopters by Industry (Treatment Sample)

\begin{tabular}{|c|c|c|c|c|c|}
\hline \multirow{2}{*}{$\begin{array}{l}\text { Industry } \\
01 \text { Petroleum industry }\end{array}$} & \multicolumn{2}{|c|}{$\begin{array}{l}\text { \% of Voluntary } \\
\text { IFRS Adopters }\end{array}$} & \multirow{2}{*}{$\begin{array}{l}\text { Industry } \\
07 \text { Capital goods industry }\end{array}$} & \multicolumn{2}{|c|}{$\begin{array}{l}\text { \% of Voluntary } \\
\text { IFRS Adopters }\end{array}$} \\
\hline & 8.4 & $(0)$ & & 18.3 & $(1)$ \\
\hline 02 Finance/Real estate industry & 7.5 & $(0)$ & 08 Transportation industry & 9.6 & $(0)$ \\
\hline 03 Consumer durables industry & 12.6 & (1) & 09 Utilities industry & 15.6 & (1) \\
\hline 04 Basic industry & 10.8 & (1) & 10 Textiles/Trade industry & 10.4 & $(0)$ \\
\hline 05 Food/Tobacco industry & 9.0 & $(0)$ & 11 Service industry & 10.7 & $(1)$ \\
\hline 06 Construction industry & 11.7 & $(1)$ & 12 Leisure industry & 10.2 & $(0)$ \\
\hline
\end{tabular}


The table presents IFRS announcement and adoption dates together with raw and (in parentheses) dichotomized indicator values of the institutional proxies used in the cross-sectional analyses across the 26 treatment sample countries and the 12 Campbell [1996] industries, respectively. We use the following conditional variables in the analyses: (i) the rule of law variable for the year 2005 from Kaufmann, Kraay, and Mastruzzi [2007]. Higher values represent countries with higher quality legal enforcement. (ii) We distinguish between member states of the European Union (equal to one) and the remaining IFRS adoption countries. (iii) The aggregate earnings management score from Leuz, Nanda, and Wysocki [2003]. We multiply this measure by minus one so that higher values represent countries with more transparent (or less managed) earnings. (iv) The Bae, Tan, and Welker [2008] summary score of how domestic GAAP differs from IAS on 21 key accounting dimensions. Higher values stand for more discrepancies between local GAAP and IFRS. (v) We distinguish between countries with an official convergence strategy towards IFRS prior to mandatory adoption (equal to one) and the remaining IFRS adoption countries. (vi) In the year before mandatory IFRS reporting, we measure the percentage of firms voluntarily reporting under IFRS in a given industry (see Panel B). Note that for the variables (iii) and (iv), rather than using raw values, we partition the treatment sample based on the residuals from a regression of the institutional variables on countries' legal origin (La Porta et al. [1998]) and the log transformed average GDP per capita in constant US\$ over the nineties (source: World Bank). For our analyses, we transform the continuous variables into binary variables splitting by the median computed over the treatment sample or industries. We determine the dates when local authorities announced their plans to require IFRS reporting, the dates when IFRS reporting becomes mandatory as well as the existence of an official IFRS convergence strategy based on Deloitte's IAS Plus website (www.iasplus.com), press articles found on LexisNexis, and the websites of major national stock exchanges. 
TABLE 7

Cross-Sectional Analysis of the Liquidity Effects around the IFRS Mandate

\begin{tabular}{|c|c|c|c|c|c|c|}
\hline \multirow{2}{*}{$\begin{array}{l}\text { (Liquidity Factor as } \\
\text { Dependent Variable) }\end{array}$} & \multicolumn{5}{|c|}{$\begin{array}{l}\text { Country-Level Institutions } \\
\text { as Conditional Variables }\end{array}$} & \multirow{2}{*}{$\begin{array}{c}\text { Conditioned on } \\
\text { Industry Level } \\
\text { Model 6: } \\
\text { \% of Voluntary } \\
\text { IFRS Adopters } \\
(1=\text { Higher } \\
\text { Percentage })\end{array}$} \\
\hline & $\begin{array}{c}\text { Model 1: } \\
\text { Rule of Law } \\
(1=\text { Stricter } \\
\text { Enforcement })\end{array}$ & $\begin{array}{c}\text { Model 2: } \\
\text { Membership in } \\
\text { the European } \\
\text { Union } \\
(1=\text { Yes })\end{array}$ & $\begin{array}{c}\text { Model 3: } \\
\text { Aggregate } \\
\text { Earnings } \\
\text { Management } \\
\text { (1 = More Trans- } \\
\text { parent Earnings })\end{array}$ & $\begin{array}{c}\text { Model 4: } \\
\text { Difference } \\
\text { Between Local } \\
\text { GAAP and IFRS } \\
(1=\text { More } \\
\text { Discrepancies })\end{array}$ & $\begin{array}{c}\text { Model 5: } \\
\text { IFRS } \\
\text { Convergence } \\
\text { Strategy } \\
(1=\text { Yes })\end{array}$ & \\
\hline \multicolumn{7}{|l|}{ IFRS Adopter Types: } \\
\hline (1) Voluntary & $\begin{array}{l}-3.04 \\
(-0.94)\end{array}$ & $\begin{array}{l}11.72 \\
(1.42)\end{array}$ & $\begin{array}{l}-2.11 \\
(-0.54)\end{array}$ & $\begin{array}{l}10.45 \\
(1.24)\end{array}$ & $\begin{array}{l}-6.05 * * \\
(-2.46)\end{array}$ & $\begin{array}{l}-4.17 \\
(-1.32)\end{array}$ \\
\hline (2) Voluntary*Conditional Variable & $\begin{array}{l}-2.85 \\
(-0.61)\end{array}$ & $\begin{array}{l}-18.08 * * \\
(-2.11)\end{array}$ & $\begin{array}{l}-2.95 \\
(-0.60)\end{array}$ & $\begin{array}{l}-15.77 * \\
(-1.79)\end{array}$ & $\begin{array}{l}31.30 * * * \\
(3.48)\end{array}$ & $\begin{array}{l}0.27 \\
(0.06)\end{array}$ \\
\hline Test of $(1)+(2)=0[p$-Value $]$ & {$[0.09]$} & {$[0.01]$} & {$[0.10]$} & {$[0.04]$} & {$[0.00]$} & {$[0.27]$} \\
\hline (3) Voluntary*Mandatory & $\begin{array}{c}2.64 \\
(1.11)\end{array}$ & $\begin{array}{c}-4.05 \\
(-1.18)\end{array}$ & $\begin{array}{c}-0.74 \\
(-0.32)\end{array}$ & $\begin{array}{c}3.11 \\
(\mathbf{0 . 6 0})\end{array}$ & $\begin{array}{l}-5.39 * * * \\
(-3.25)\end{array}$ & $\begin{array}{l}-4.90 * \\
(-1.68)\end{array}$ \\
\hline (4) Voluntary*Mandatory* & $-8.66 * * *$ & -0.67 & $-8.70 * * *$ & -8.33 & 5.54 & 2.20 \\
\hline $\begin{array}{c}\text { Conditional Variable } \\
\text { Test of }(3)+(4)=0[p-V a l u e]\end{array}$ & $\begin{array}{r}(-3.10) \\
{[0.00]}\end{array}$ & $\begin{array}{r}(-0.19) \\
{[0.01]}\end{array}$ & $\begin{array}{r}(-3.13) \\
{[0.00]}\end{array}$ & $\begin{array}{r}(-1.58) \\
{[0.00]}\end{array}$ & $\begin{array}{l}(0.69) \\
{[0.98]}\end{array}$ & $\begin{array}{l}(\mathbf{0 . 6 1}) \\
{[0.20]}\end{array}$ \\
\hline (5) First-Time Mandatory & $\begin{array}{c}1.54 \\
(0.99)\end{array}$ & $\begin{array}{l}3.20 * \\
(1.91)\end{array}$ & $\begin{array}{c}0.02 \\
(0.01)\end{array}$ & $\begin{array}{l}-2.69 * \\
(-1.81)\end{array}$ & $\begin{array}{l}-11.11 * * * \\
(-7.71)\end{array}$ & $\begin{array}{l}-7.35 * * * \\
(-4.13)\end{array}$ \\
\hline (6) First-Time Mandatory* & $-9.40 * * *$ & $-13.90 * * * *$ & $-9.59 * * *$ & $-4.75 * *$ & $16.66 * * *$ & $5.48 * *$ \\
\hline Conditional Variable & $(-5.12)$ & $(-7.09)$ & $(-4.96)$ & $(-2.54)$ & $(8.21)$ & $(2.21)$ \\
\hline Test of $(5)+(6)=0$ [p-Value] & {$[0.00]$} & {$[0.00]$} & {$[0.00]$} & {$[0.00]$} & {$[0.00]$} & {$[0.28]$} \\
\hline $\begin{array}{l}\text { Control Variables, Firm-Fixed and } \\
\text { Industry-Year-Fixed Effects }\end{array}$ & Included & Included & Included & Included & Included & Included \\
\hline $\mathrm{R}^{2}$ & 0.86 & 0.86 & 0.86 & 0.86 & 0.86 & 0.86 \\
\hline \# Observations & 31,407 & 31,407 & 30,933 & 31,407 & 31,407 & 31,407 \\
\hline \# Unique Firms & 8,622 & 8,622 & 8,494 & 8,622 & 8,622 & 8,622 \\
\hline \# Countries & 36 & 36 & 34 & 36 & 36 & 36 \\
\hline
\end{tabular}


The sample comprises up to 31,407 firm-year observations from 36 countries between 2001 and 2005, and combines the treatment sample with a maximum of 150 randomly selected firms from each benchmark sample country (see Table 1). We report results for the Liquidity Factor as dependent variable, i.e., the scores of a single factor extracted from the four liquidity variables (zero returns, price impact, total trading costs and bid-ask spreads) employing factor analysis with oblique rotation. We classify IFRS observations of treatment sample firms into two distinctive categories using binary indicator variables: (1) Voluntary marks the subset of firms voluntarily switching to IFRS before it was mandated by local regulation. (2) First-Time Mandatory indicates firm-years ending after IFRS adoption becomes mandatory and applies only to firms that have never reported under IFRS before. To capture the marginal effect of the IFRS mandate on voluntary adopters, we introduce another binary indicator variable, Mandatory, that takes on the value of one for firm-years ending on or after the local adoption date for mandatory IFRS reporting and interact it with Voluntary. We report results for the following country- and industry-level conditional variables: (i) the rule of law variable for the year 2005 from Kaufmann, Kraay, and Mastruzzi [2007]. (ii) We distinguish between member states of the European Union and the remaining IFRS adoption countries. (iii) The aggregate earnings management score from Leuz, Nanda, and Wysocki [2003]. (iv) The Bae, Tan, and Welker [2008] summary score of how domestic GAAP differs from IAS on 21 key accounting dimensions. (v) We distinguish between countries with an official convergence strategy towards IFRS prior to mandatory adoption and the remaining IFRS adoption countries. (vi) In the year before mandatory IFRS reporting, we measure the percentage of firms voluntarily reporting under IFRS in a given industry. Note that for the variables (iii) and (iv), rather than using raw values, we partition the treatment sample based on the residuals from a regression of the institutional variables on countries' legal origin (La Porta et al. [1998]) and the log transformed average GDP per capita in constant US\$ over the nineties (source: World Bank). For our analyses, we transform the continuous variables into binary variables splitting by the median computed over the treatment sample countries or industries. The table reports only the IFRS adopter type variables together with the interactions with the conditional variables, but the full set of controls and fixed-effects is included in the regressions. See the base model in Panel A of Table 4 for details. The table reports OLS coefficient estimates and (in parentheses) t-statistics based on robust standard errors that are clustered by firm. It also reports p-values from Wald tests assessing the statistical significance of the sum of two coefficients where indicated. For expositional purposes we multiply all coefficients by 100 . ***, **, and * indicate statistical significance at the $1 \%$, $5 \%$, and $10 \%$ levels (twotailed), respectively. 
TABLE 8

Country-Month Analysis of the Liquidity Effects around the IFRS Mandate

Panel A: Descriptive Statistics of Dependent and Independent Variables

\begin{tabular}{|c|c|c|c|c|c|c|c|c|}
\hline Variables & $N$ & Mean & Std. Dev. & $P 1$ & $P 25$ & Median & $P 75$ & $P 99$ \\
\hline$\Delta$ Zero Returns & 360 & $-0.83 \%$ & $6.72 \%$ & $-16.96 \%$ & $-4.55 \%$ & $-0.89 \%$ & $3.12 \%$ & $15.81 \%$ \\
\hline$\Delta$ Price Impact & 330 & -0.003 & 0.220 & -0.820 & -0.027 & -0.002 & 0.014 & 0.619 \\
\hline$\Delta$ Bid-Ask Spread & 315 & $0.00 \%$ & $0.34 \%$ & $-1.09 \%$ & $-0.12 \%$ & $-0.02 \%$ & $0.09 \%$ & $0.78 \%$ \\
\hline$\Delta$ IFRS Adoption Rate FYE & 360 & $6.7 \%$ & $20.6 \%$ & $0.0 \%$ & $0.0 \%$ & $0.2 \%$ & $1.9 \%$ & $97.0 \%$ \\
\hline$\Delta$ IFRS Adoption Rate $_{\text {Interim }}$ & 656 & $7.4 \%$ & $18.7 \%$ & $0.0 \%$ & $0.0 \%$ & $1.1 \%$ & $4.6 \%$ & $108.8 \%$ \\
\hline Market Value & 360 & 151.3 & 161.8 & 17.3 & 47.1 & 96.4 & 164.6 & 789.3 \\
\hline Return Variability & 360 & 0.087 & 0.027 & 0.051 & 0.066 & 0.085 & 0.100 & 0.184 \\
\hline$\Delta$ Market Benchmark ${ }_{\text {Zero Returns }}$ & 360 & $-0.31 \%$ & $4.94 \%$ & $-9.86 \%$ & $-3.81 \%$ & $1.14 \%$ & $2.61 \%$ & $8.23 \%$ \\
\hline$\Delta$ Market Benchmark ${ }_{\text {Price Impacty }}$ & 360 & 0.000 & 0.019 & -0.024 & -0.010 & -0.006 & 0.010 & 0.049 \\
\hline$\Delta$ Market Benchmark Bid-Ask Spread & 360 & $-0.01 \%$ & $0.07 \%$ & $-0.17 \%$ & $-0.04 \%$ & $-0.01 \%$ & $0.02 \%$ & $0.16 \%$ \\
\hline
\end{tabular}

Panel B: Regression Analysis

\begin{tabular}{|c|c|c|c|c|c|c|c|c|c|}
\hline \multirow[t]{2}{*}{ Variables } & \multicolumn{3}{|c|}{$\Delta$ Zero Returns $_{m}$} & \multicolumn{3}{|c|}{$\Delta{\text { Price } \text { Impact }_{m}}$} & \multicolumn{3}{|c|}{$\Delta$ Bid-Ask Spread $_{m}$} \\
\hline & $\begin{array}{c}\text { Model 1: } \\
\text { Annual } \\
\text { Reports, All } \\
\text { Observations }\end{array}$ & $\begin{array}{l}\text { Model 2: } \\
\text { Annual } \\
\text { Reports, } \\
\text { Biggest } \\
\text { Changes }\end{array}$ & $\begin{array}{c}\text { Model 3: } \\
\text { Interim and } \\
\text { Annual Re- } \\
\text { ports, Biggest } \\
\text { Changes }\end{array}$ & $\begin{array}{c}\text { Model 1: } \\
\text { Annual } \\
\text { Reports, All } \\
\text { Observations }\end{array}$ & $\begin{array}{l}\text { Model 2: } \\
\text { Annual } \\
\text { Reports, } \\
\text { Biggest } \\
\text { Changes }\end{array}$ & $\begin{array}{c}\text { Model 3: } \\
\text { Interim and } \\
\text { Annual Re- } \\
\text { ports, Biggest } \\
\text { Changes }\end{array}$ & $\begin{array}{c}\text { Model 1: } \\
\text { Annual } \\
\text { Reports, All } \\
\text { Observations }\end{array}$ & $\begin{array}{c}\text { Model 2: } \\
\text { Annual } \\
\text { Reports, } \\
\text { Biggest } \\
\text { Changes }\end{array}$ & $\begin{array}{c}\text { Model 3: } \\
\text { Interim and } \\
\text { Annual Re- } \\
\text { ports, Biggest } \\
\text { Changes }\end{array}$ \\
\hline$\Delta$ IFRS Adoption Rate ${ }_{F Y E, m}$ & $\begin{array}{c}-1.07 \\
(-0.74)\end{array}$ & $\begin{array}{l}-4.22 * \\
(-1.68)\end{array}$ & & $\begin{array}{c}-0.09 \\
(-0.02)\end{array}$ & $\begin{array}{c}-6.76 \\
(-1.12)\end{array}$ & & $\begin{array}{c}-0.02 \\
(-0.41)\end{array}$ & $\begin{array}{c}-0.19 * \\
(-1.73)\end{array}$ & \\
\hline$\Delta$ IFRS Adoption Rate Interim, $m_{m}$ & & & $\begin{array}{l}-4.18 * * \\
(-2.43)\end{array}$ & & & $\begin{array}{c}-6.13 \\
(-1.12)\end{array}$ & & & $\begin{array}{c}-0.16 * \\
(-1.65)\end{array}$ \\
\hline \multicolumn{10}{|l|}{ Control Variables: } \\
\hline Log(Market Value $\left.{ }_{m-12}\right)$ & $\begin{array}{c}-3.77 \\
(-0.92)\end{array}$ & $\begin{array}{l}-17.79 \\
(-1.66)\end{array}$ & $\begin{array}{c}3.21 \\
(0.75)\end{array}$ & $\begin{array}{c}5.28 \\
(0.52)\end{array}$ & $\begin{array}{l}35.06 \\
(1.14)\end{array}$ & $\begin{array}{l}12.79 \\
(0.73)\end{array}$ & $\begin{array}{c}0.11 \\
(0.37)\end{array}$ & $\begin{array}{c}-1.35 \\
(-1.17)\end{array}$ & $\begin{array}{l}0.82 * \\
(1.86)\end{array}$ \\
\hline Return Variability $_{m-12}$ & $\begin{array}{l}66.50 \\
(0.83)\end{array}$ & $\begin{array}{c}458.93^{* *} \\
(2.35)\end{array}$ & $\begin{array}{c}3.59 \\
(0.05)\end{array}$ & $\begin{array}{r}-280.35 \\
(-0.91)\end{array}$ & $\begin{array}{r}-660.50 \\
(-0.93)\end{array}$ & $\begin{array}{r}-147.11 \\
(-0.58)\end{array}$ & $\begin{array}{c}-4.16 \\
(-1.32)\end{array}$ & $\begin{array}{c}2.31 \\
(0.22)\end{array}$ & $\begin{array}{c}2.79 \\
(0.46)\end{array}$ \\
\hline Dependent Variable $_{m-12}$ & $\begin{array}{c}3.27 \\
(0.35)\end{array}$ & $\begin{array}{l}26.56 \\
(1.19)\end{array}$ & $\begin{array}{l}14.42 \\
(1.17)\end{array}$ & $\begin{array}{c}-1.77 \\
(-0.22)\end{array}$ & $\begin{array}{c}1.38 \\
(0.16)\end{array}$ & $\begin{array}{c}1.41 \\
(0.27)\end{array}$ & $\begin{array}{l}13.36 \\
(1.14)\end{array}$ & $\begin{array}{l}15.31 \\
(0.58)\end{array}$ & $\begin{array}{l}21.78 \\
(1.11)\end{array}$ \\
\hline$\Delta$ Dependent Variable $_{m-12}$ & $\begin{array}{l}12.06 \\
(1.40)\end{array}$ & $\begin{array}{l}21.34 \\
(1.25)\end{array}$ & $\begin{array}{c}1.78 \\
(0.16)\end{array}$ & $\begin{array}{l}16.10 * \\
(1.67)\end{array}$ & $\begin{array}{c}9.62 \\
(0.60)\end{array}$ & $\begin{array}{c}23.57 * \\
(1.76)\end{array}$ & $\begin{array}{l}10.77 \\
(1.18)\end{array}$ & $\begin{array}{l}17.48 \\
(1.02)\end{array}$ & $\begin{array}{c}6.96 \\
(0.42)\end{array}$ \\
\hline$\Delta$ Market Benchmark $_{m}$ & $\begin{array}{c}-3.78 \\
(-0.58)\end{array}$ & $\begin{array}{c}6.45 \\
(0.39)\end{array}$ & $\begin{array}{l}14.86 \\
(0.87)\end{array}$ & $\begin{array}{c}238.37 * * * \\
(4.10)\end{array}$ & $\begin{array}{c}382.70 * * \\
(2.41)\end{array}$ & $\begin{array}{c}370.32 * * * \\
(3.90)\end{array}$ & $\begin{array}{l}201.68 * * * \\
(7.06)\end{array}$ & $\begin{array}{c}198.03 * * * \\
(3.92)\end{array}$ & $\begin{array}{c}231.95 * * * \\
(4.14)\end{array}$ \\
\hline Country-Fixed Effects & Included & Included & Included & Included & Included & Included & Included & Included & Included \\
\hline $\mathrm{R}^{2}$ & 0.03 & 0.29 & 0.13 & 0.11 & 0.43 & 0.38 & 0.22 & 0.31 & 0.37 \\
\hline \# Observations & 360 & 96 & 169 & 330 & 86 & 155 & 315 & 84 & 150 \\
\hline
\end{tabular}


The sample used in Models 1 and 2 comprises a maximum of 360 country-month observations from 26 treatment sample countries over the 15-month period during which mandatory IFRS annual reports become initially available (e.g., for all countries except Singapore, the sample window runs from January 2006 through March 2007). In Model 3, we extend the above window by the 12 months leading up to the release of the annual reports in order to allow for interim reporting effects, yielding a maximum sample of 656 country-month observations. We include only firms that report under IFRS for the first time in the year IFRS become mandatory. Panel A presents descriptive statistics for the dependent and independent variables. Panel B reports OLS coefficient estimates and, in parenthesis, t-statistics based on robust standard errors from country-month regressions using a changes specification. We use three dependent variables in the analyses: (1) Zero Returns is the proportion of trading days with zero daily stock returns out of all potential trading days in a given country and month. (2) Price Impact is the monthly median of the Amihud [2002] illiquidity measure (i.e., daily absolute stock return divided by US\$ trading volume) in a given country. (3) The Bid-Ask Spread is the monthly median quoted spread (i.e., difference between the bid and ask price divided by the mid-point and measured at the end of each trading day) in a given country. The independent variables consist of the following measures: $\triangle$ IFRS Adoption Rate is the month-to-month change in the cumulative proportion of firms in a given country that are required to follow IFRS for the first time. For $\triangle$ IFRS Adoption Rate $F Y$, we assume that a firm releases annual financial statement information three months after its fiscal year end (FYE). That is, in computing the cumulative adoption rate, we assign the value of one to each month $m$ starting in month 3 after a firm's FYE, and then aggregate by country and month. For $\Delta$ IFRS Adoption Rate Interim $_{\text {, we }}$ extend the above measurement window to include interim reporting. In addition to the coding of the annual financial information, we start adding 0.25 ( 0.5 ) in the release month of each quarterly (semi-annual) financial report. To determine the release of interim and annual information, we use the month of the earnings announcement dates as reported in $I / B / E / S$. If this data is missing, we first gather the interim reporting rules in a particular country (source: LexisNexis and websites of major national stock exchanges), and then allow two months for interim information to be released. We further assume that fourth quarter reports and second half-year reports are released together with annual reports. Thus, the cumulative adoption rate is below one during the period of interim reporting and then goes up to two when firms release their annual financial statement information. Models 2 and 3 limit the analysis to the countrymonth observations with the biggest changes in the IFRS adoption rate, i.e., changes that fall into the upper quartile of the distribution. Market Value is stock price times the number of shares outstanding (in US\$ millions) at the end of month $m-12$. We use the natural log of market value in the analysis. We compute Return Variability as standard deviation of the previous 12 monthly stock returns measured at time $m$ - 12 . We include the level of the dependent variable and the change therein measured at month $m-12$ to account for seasonal and calendar time effects. We define a contemporaneous Market Benchmark as the average dependent variable drawn from 100 random benchmark samples. For each random draw, we compute monthly medians of the dependent variable from a maximum of 150 randomly selected observations per benchmark country. $\Delta$ stands for changes in the variables computed over month $m$ - 1 to $m$. We aggregate all firm-level variables in a given country and month by computing medians. We include an intercept and country-fixed effects in the regressions but do not report the coefficients. For expositional purposes, we multiply all coefficients by $100 . * * *, * *$, and $*$ indicate statistical significance at the $1 \%, 5 \%$, and $10 \%$ levels (two-tailed), respectively. 